medRxiv preprint doi: https://doi.org/10.1101/2021.06.29.21259427; this version posted July 3, 2021. The copyright holder for this preprint (which was not certified by peer review) is the author/funder, who has granted medRxiv a license to display the preprint in perpetuity. It is made available under a CC-BY-NC-ND 4.0 International license .

\title{
Convalescent plasma for hospitalized patients with COVID-19 and the effect of plasma antibodies: a randomized controlled, open-label trial
}

The CONCOR-1 Study Group

CONCOR-1 writing committee: Philippe Bégin,* Jeannie Callum,* Erin Jamula, Richard Cook, Nancy M. Heddle, Alan Tinmouth, Michelle P. Zeller, Guillaume Beaudoin-Bussières, Luiz Amorim, Renée Bazin, Kent Cadogan Loftsgard, Richard Carl, Michaël Chassé, Melissa M. Cushing, Nick Daneman, Dana V. Devine, Jeannot Dumaresq, Dean A. Fergusson, Caroline Gabe, Marshall J. Glesby, Na Li, Yang Liu, Allison McGeer, Nancy Robitaille, Bruce S. Sachais, Damon C. Scales, Lisa Schwartz, Nadine Shehata, Alexis F. Turgeon, Heidi Wood, Ryan Zarychanski, Andrés Finzi and Donald M. Arnold* for the CONCOR-1 Study Group†.

*These authors contributed equally to the manuscript.

$\dagger$ Please refer to the appendix for the complete list of CONCOR-1 investigators and collaborators

Section of Allergy, Immunology and Rheumatology, Department of Pediatrics, CHU SainteJustine, Montréal, Québec, Canada (P Bégin MD, PhD)

Department of Medicine, Centre Hospitalier de l’Université de Montréal, Montréal, Québec, Canada (P Bégin MD, PhD)

Department of Pathology and Molecular Medicine, Kingston Health Sciences Centre and Queen's University, Kingston, Ontario, Canada (J Callum MD)

Department of Laboratory Medicine and Molecular Diagnostics, Sunnybrook Health Sciences Centre, Toronto, Ontario, Canada; Department of Laboratory Medicine and Pathobiology, University of Toronto, Toronto, Ontario, Canada (J Callum MD)

Canadian Blood Services, Ottawa, Ontario, Canada (J Callum MD, NM Heddle MSc, A Tinmouth MD, MP Zeller MD, DA Fergusson PhD, N Shehata MD)

Department of Statistics and Actuarial Science, University of Waterloo, Waterloo, Ontario, Canada (R Cook PhD)

Department of Medicine, McMaster University, Hamilton, Ontario, Canada (NM Heddle MSc, MP Zeller MD, DM Arnold MD, MSc)

McMaster Centre for Transfusion Research, McMaster University, Hamilton, Ontario, Canada (Erin Jamula, NM Heddle MSc, MP Zeller MD, C Gabe MD, N Li PhD, Y Liu MMath, DM Arnold MD, MSc)

Department of Medicine, University of Ottawa, Ottawa, Ontario, Canada (A Tinmouth MD, DA Fergusson PhD)

Ottawa Hospital Centre for Transfusion Research, Ottawa Hospital Research Institute, Ottawa, Ontario, Canada (A Tinmouth MD) 
medRxiv preprint doi: https://doi.org/10.1101/2021.06.29.21259427; this version posted July 3, 2021. The copyright holder for this preprint (which was not certified by peer review) is the author/funder, who has granted medRxiv a license to display the preprint in perpetuity. It is made available under a CC-BY-NC-ND 4.0 International license .

Département de Microbiologie, Infectiologie et Immunologie, Université de Montréal, Montréal, Québec, Canada (G Beaudoin-Bussières PhD, A Finzi PhD)

CHUM Research Center, Montréal, Québec, Canada (G Beaudoin-Bussières PhD, A Finzi PhD)

Hemorio, Rio de Janeiro, Brazil (L Amorim MD)

Héma-Québec, Medical Affairs and Innovation, Québec City, Québec, Canada (R Bazin PhD)

Community Advisory Committee representative (K Cadogan Loftsgard)

Patient representative (R Carl)

Innovation Hub, Centre de Recherche du Centre Hospitalier de l’Université de Montréal, Montréal, Québec, Canada (M Chassé MD, PhD)

Department of Medicine (Critical Care), Centre Hospitalier de l'Université de Montréal (CHUM), Montréal, Québec, Canada (MChassé MD, PhD)

Transfusion Medicine and Cellular Therapy, New York-Presbyterian, New York, NY, USA (MM Cushing MD)

Department of Pathology and Laboratory Medicine, Weill Cornell Medicine, New York, NY, USA (MM Cushing MD, BS Sachais MD, PhD)

Department of Medicine, Division of Infectious Diseases, Sunnybrook Health Sciences Centre, University of Toronto, Toronto, Ontario, Canada (N Daneman MD)

Canadian Blood Services, Vancouver, British Columbia, Canada (DV Devine PhD)

Department of Pathology and Laboratory Medicine, University of British Columbia, Vancouver British Columbia, Canada (DV Devine PhD)

Département de médecine, CISSS de Chaudière-Appalaches, Lévis, Québec, Canada (J Dumaresq MD)

Département de microbiologie-infectiologie et d’immunologie, Faculté de Médecine, Université Laval, Québec, Québec, Canada (J Dumaresq MD)

Clinical Epidemiology Program, Ottawa Hospital Research Institute, Ottawa, Ontario, Canada (DA Fergusson $\mathrm{PhD}$ )

Division of Infectious Diseases, Weill Cornell Medical College, New York, NY, USA (MJ Glesby $\mathrm{MD}, \mathrm{PhD})$

Department of Community Health Sciences, University of Calgary, Calgary, Alberta, Canada (N Li $\mathrm{PhD})$

Department of Computing and Software, McMaster University, Hamilton, Ontario, Canada (N Li $\mathrm{PhD}$ ) 
medRxiv preprint doi: https://doi.org/10.1101/2021.06.29.21259427; this version posted July 3, 2021. The copyright holder for this preprint (which was not certified by peer review) is the author/funder, who has granted medRxiv a license to display the preprint in perpetuity. It is made available under a CC-BY-NC-ND 4.0 International license .

Department of Microbiology, Sinai Health System, Toronto, Ontario, Canada (A McGeer MD)

Department of Laboratory Medicine and Pathobiology and Dalla Lana School of Public Health, University of Toronto, Toronto, Ontario, Canada (A McGeer MD)

Héma-Québec, Montréal, Québec, Canada (N Robitaille MD)

Division of Hematology and Oncology, Department of Pediatrics, CHU Sainte-Justine, Montréal, Québec, Canada (N Robitaille MD)

Department of Pediatrics, Université de Montréal, Montréal, Québec, Canada (N Robitaille MD)

New York Blood Center Enterprises, New York, NY, USA (BS Sachais MD, PhD)

Department of Critical Care Medicine, Sunnybrook Health Sciences Centre, Toronto, Ontario, Canada (DC Scales MD, PhD)

Department of Medicine, Interdepartmental Division of Critical Care Medicine, University of Toronto, Toronto, Ontario, Canada (DC Scales MD, PhD)

Department of Health Research Methods, Evidence \& Impact, Faculty of Health Sciences, McMaster University, Hamilton, Ontario, Canada (L Schwartz PhD)

Departments of Medicine, Laboratory Medicine and Pathobiology, Institute of Health Policy Management and Evaluation, University of Toronto, Toronto, Ontario, Canada (N Shehata MD)

Division of Hematology, Mount Sinai Hospital, Toronto, Ontario, Canada (N Shehata MD)

Department of Anesthesiology and Critical Care Medicine, Division of Critical Care Medicine, Faculty of Medicine, Université Laval, Québec City, Québec, Canada (AF. Turgeon MD, MSc)

CHU de Québec - Université Laval Research Centre, Population Health and Optimal Health Practices Research Unit, Trauma -Emergency - Critical Care Medicine, Université Laval, Québec City, Québec, Canada (AF Turgeon MD, MSc)

Zoonotic Diseases and Special Pathogens, National Microbiology Laboratory, Public Health Agency of Canada, Winnipeg, Manitoba, Canada (H Wood PhD)

Department of Internal Medicine, Sections of Hematology/Medical Oncology and Critical Care, University of Manitoba, Winnipeg, Manitoba, Canada (R Zarychanski MD, MSc)

\section{Corresponding Authors:}

Dr Philippe Bégin, philippe.begin.med@ssss.gouv.qc.ca, ORCID: 0000-0002-9089-4604

Dr Jeannie Callum, jeannie.callum@kingstonhsc.ca, ORCID: 0000-0003-0943-8853

Dr Donald M. Arnold, arnold@mcmaster.ca, ORCID: 0000-0001-6133-0677 
medRxiv preprint doi: https://doi.org/10.1101/2021.06.29.21259427; this version posted July 3, 2021. The copyright holder for this preprint (which was not certified by peer review) is the author/funder, who has granted medRxiv a license to display the preprint in perpetuity.

It is made available under a CC-BY-NC-ND 4.0 International license.

Reprint Requests: Dr. Donald M. Arnold, McMaster Centre for Transfusion Research, McMaster University HSC- 3H50, 1280 Main St. West, Hamilton, Ontario, L8S 4K1; email:

arnold@mcmaster.ca

Grant Support: Canadian Institutes of Health Research - COVID-19 May 2020 Rapid Research Funding Opportunity - Operating Grant; Ontario COVID-19 Rapid Research Fund; Toronto COVID-19 Action Initiative 2020 (University of Toronto); University Health Network Emergent Access Innovation Fund; University Health Academic Health Science Centre Alternative Funding Plan (Sunnybrook Health Sciences Centre); Ministère de l'Économie et de l'Innovation (Québec); Fond de Recherche du Québec en Santé; Saskatchewan Ministry of Health; University of Alberta Hospital Foundation; Alberta Health Services COVID-19 Foundation Competition; Sunnybrook Health Sciences Centre Foundation; Fondations CHU Ste-Justine; The Ottawa Hospital Academic Medical Organization; The Ottawa Hospital Foundation COVID-19 Research Fund; Fondation du CHUM; Sinai Health System Foundation and McMaster University.

Short running title: Convalescent Plasma for COVID-19

Keywords: Convalescent Plasma, COVID-19, Pneumonia, Antibodies

Words: 3,515 
medRxiv preprint doi: https://doi.org/10.1101/2021.06.29.21259427; this version posted July 3, 2021. The copyright holder for this preprint (which was not certified by peer review) is the author/funder, who has granted medRxiv a license to display the preprint in perpetuity. It is made available under a CC-BY-NC-ND 4.0 International license .

\section{Abstract}

The efficacy of convalescent plasma for COVID-19 is unclear. While most randomized controlled trials have shown negative results, uncontrolled studies have suggested that the antibody content may influence patient outcomes.

We conducted an open-label, randomized controlled trial of convalescent plasma for adults with COVID-19 receiving oxygen within 12 days of respiratory symptom onset. Patients were allocated 2:1 to $500 \mathrm{~mL}$ of convalescent plasma or standard of care. The composite primary outcome was intubation or death by 30 days. The effect of convalescent plasma antibodies on the primary outcome was assessed by logistic regression.

The trial was terminated at $78 \%$ of planned enrollment after meeting stopping criteria for futility. 940 patients were randomized and 921 patients were included in the intent-to-treat analysis. Intubation or death occurred in 199/614 (32.4\%) in the convalescent plasma arm and 86/307 (28.0\%) in the standard of care arm; relative risk (RR) 1.16 (95\% confidence interval (CI) 0.941.43; $\mathrm{p}=0.18$ ). Patients in the convalescent plasma arm had more serious adverse events (33.4\% vs. 26.4\%; RR=1.27, 95\% CI 1.02-1.57, $\mathrm{p}=0.034)$. The antibody content significantly modulated the therapeutic effect of convalescent plasma. In multivariate analysis, each standard log increase in neutralization or antibody-dependent cellular cytotoxicity independently reduced the potential harmful effect of plasma (OR=0.74; 0.57-0.95 and $\mathrm{OR}=0.66 ; 0.50-0.87$, respectively), while IgG against the full transmembrane Spike protein increased it (OR=1.53, 95\% CI 1.14-2.05).

Convalescent plasma did not reduce the risk of intubation or death at 30 days among hospitalized patients with COVID-19. Transfusion of convalescent plasma with unfavourable antibody profiles may be associated with worse clinical outcomes compared to standard care. 
medRxiv preprint doi: https://doi.org/10.1101/2021.06.29.21259427; this version posted July 3, 2021. The copyright holder for this preprint (which was not certified by peer review) is the author/funder, who has granted medRxiv a license to display the preprint in perpetuity. It is made available under a CC-BY-NC-ND 4.0 International license.

Trial registration: CONvalescent Plasma for Hospitalized Adults With COVID-19 Respiratory

Illness (CONCOR-1); NCT04348656; https://www.clinicaltrials.gov/ct2/show/NCT04348656 
medRxiv preprint doi: https://doi.org/10.1101/2021.06.29.21259427; this version posted July 3, 2021. The copyright holder for this preprint (which was not certified by peer review) is the author/funder, who has granted medRxiv a license to display the preprint in perpetuity.

It is made available under a CC-BY-NC-ND 4.0 International license .

\section{Introduction}

The immune response after SARS-CoV-2 infection results in the formation of antibodies that can interfere with viral replication and infection of host cells in over $95 \%$ of patients. ${ }^{1}$ Based on prior experience in other viral infections, ${ }^{2}$ the use of convalescent plasma has been proposed as a therapeutic form of passive immunization for patients with acute Coronavirus Disease 2019 (COVID-19). ${ }^{3,4}$ Early in the pandemic, several small randomized trials found no difference in clinical outcomes. ${ }^{5-8}$ In the United States, an Extended Access Program outside of a controlled trial led to the use of convalescent plasma in over half a million patients. Data from these patients showed that the transfusion of plasma with high anti-SARS-CoV-2 antibody level was associated with a lower risk of death in non-intubated patients compared with lower antibody levels; however, this study lacked a control group. ${ }^{9}$ The RECOVERY trial was a large randomized trial in 11,558 hospitalized patients, which found the risk of death following administration of high-titer plasma was not different from standard of care. ${ }^{10}$

The Convalescent Plasma for COVID-19 Respiratory Illness (CONCOR-1) trial was a multi-center, international, open-label, randomized controlled trial designed to assess the effectiveness and safety of COVID-19 convalescent plasma in hospitalized patients. The trial used plasma collected from four blood suppliers with a range of anti-SARS-CoV-2 antibody levels. The variability in antibody titers allowed for a characterization of the effect-modifying role of functional and quantitative antibodies on the primary outcome (intubation or death at 30 days). 


\section{Methods}

\section{Trial Design and Oversight}

CONCOR-1 was an investigator-initiated, multi-center, open-label, randomized controlled trial conducted at 72 hospital sites in Canada, the United States, and Brazil. ${ }^{11}$ Eligible patients were randomly assigned to receive either convalescent plasma or standard of care. The study was approved by Clinical Trials Ontario (Research Ethics Board of Record: Sunnybrook Health Sciences Centre), project \#2159; the Quebec Ministry of Health and Social Services multicenter ethics review (REB of Record: Comité d'éthique de la recherche du CHU Sainte-Justine), project \#MP-21-2020-2863; the Weil Cornell Medicine General Institutional Review Board, protocol number 20-04021981; as well as the Comissão Nacional de Ética em Pesquisa, approval 4.305.792. Regulatory authorization was obtained from Health Canada (Control \# 238201) and the United States Food and Drug Administration (IND 22075). The trial was registered at clinicaltrials.gov (NCT04348656). An Independent Data Safety Monitoring Committee performed trial oversight and made recommendations following review of safety reports planned at every 100 patients and at the planned interim analysis based on the first 600 patients. External monitoring was performed at all sites to assess protocol adherence, reporting of adverse events, and accuracy of data entry. The full details of the study design, conduct, oversight, and analyses are provided in the protocol and statistical analysis plan, which are available online.

\section{Participants}

Eligible participants were $\geq 16$ in Canada or $\geq 18$ years of age in the United States and Brazil who were admitted to the hospital ward with confirmed COVID-19 and who required supplemental oxygen. The availability of ABO-compatible convalescent plasma from donors who had recovered from COVID-19 infection was an eligibility requirement. Exclusion criteria were: more than 12 days from the onset of respiratory symptoms, imminent or current intubation, a contraindication to 
medRxiv preprint doi: https://doi.org/10.1101/2021.06.29.21259427; this version posted July 3, 2021. The copyright holder for this preprint (which was not certified by peer review) is the author/funder, who has granted medRxiv a license to display the preprint in perpetuity. It is made available under a CC-BY-NC-ND 4.0 International license .

plasma transfusion, or a plan for no active treatment. Consent was obtained from all donors and participants (or their legally authorized representative).

\section{Randomization and Intervention}

Patients were randomized in a 2:1 ratio to receive convalescent plasma or standard of care using a secure, concealed, computer-generated, web-accessed randomization sequence (REDCap).

Randomization was stratified by site and age ( $<60$ and $\geq 60$ years) with allocation made with permuted blocks of size 3 or 6 . Patients randomized to convalescent plasma received one or two units of apheresis plasma amounting to approximately $500 \mathrm{~mL}$ from one or two donors. The plasma was stored frozen and thawed as per standard blood bank procedures and infused within 24 hours of randomization. Patients were monitored by clinical staff for transfusion-related adverse events as per local procedures. Individuals assigned to standard of care received usual medical care as per routine practices at each site. The investigational product was prepared by Canadian Blood Services and Héma-Québec (Canada), New York Blood Center (USA), ${ }^{12}$ and Hemorio (Brazil). Each supplier had different criteria for qualifying convalescent plasma units that were based on the presence of either viral neutralizing antibodies at a titer of $>1: 160$ or antibodies against the receptor binding domain (RBD) of the SARS-CoV-2 Spike protein at a titer of $>1: 100$. In addition, a sample from each plasma donation was tested at reference laboratories after the transfusion for: (1)

anti-RBD antibodies (IgM, IgA and IgG) by enzyme-linked immunosorbent assay (ELISA); ${ }^{13,14}$ (2) viral neutralization by the plaque-reduction neutralization test using live virus; ${ }^{15,16}$ (3) IgG antibodies binding to the full-length trimeric transmembrane SARS-CoV-2 Spike protein expressed on $293 \mathrm{~T}$ cells by flow cytometry; ${ }^{17}$ and, (4) Fc-mediated function by an antibody-dependent cellular cytotoxicity (ADCC) assay against the full Spike protein expressed on CEM.NKr cells (see supplement for complete description). ${ }^{18,19}$ For each plasma unit, the absolute antibody content was defined as the product of the unit volume and the concentration of the antibody (or functional 
medRxiv preprint doi: https://doi.org/10.1101/2021.06.29.21259427; this version posted July 3, 2021. The copyright holder for this preprint (which was not certified by peer review) is the author/funder, who has granted medRxiv a license to display the preprint in perpetuity. It is made available under a CC-BY-NC-ND 4.0 International license .

capacity) in the plasma. These calculations were used to estimate the total antibody content from the transfusion of two units.

\section{Trial Outcomes}

The primary outcome was the composite of intubation or death by day 30. Secondary outcomes were: time to intubation or death; ventilator-free days by day 30; in-hospital death by day 90; time to in-hospital death; death by day 30; length of stay in critical care and hospital; need for extracorporeal membrane oxygenation; need for renal replacement therapy; convalescent plasmaassociated adverse events; occurrence of $\geq 3$ grade adverse events by day 30 (classification of adverse events was performed using MedDRA (https://www.meddra.org/) and graded by the Common Terminology Criteria for Adverse Events, version 4.03). All transfusion-related adverse events were classified and graded by the International Society for Blood Transfusion definitions (www.isbtweb.org). All patients were followed to day 30, including a 30-day telephone visit for patients who were discharged from hospital. Patients who were in hospital beyond day 30 were followed until discharge for the purpose of determining in-hospital mortality up to day 90 .

\section{Statistical Analysis}

The primary analysis was based on the intention-to-treat population, which included all individuals who were randomized and for whom primary outcome data were available. The per-protocol population was comprised of eligible individuals who were treated according to the randomized allocation of the intervention and received two units (or equivalent) of convalescent plasma within 24 hours of randomization.

The effect of convalescent plasma on the composite primary outcome of intubation or death by day 30 was assessed by testing the null hypothesis that the composite event rate was the same under 
medRxiv preprint doi: https://doi.org/10.1101/2021.06.29.21259427; this version posted July 3, 2021. The copyright holder for this preprint (which was not certified by peer review) is the author/funder, who has granted medRxiv a license to display the preprint in perpetuity. It is made available under a CC-BY-NC-ND 4.0 International license .

convalescent plasma and standard of care. The relative risk for the primary outcome (convalescent plasma versus standard of care) was computed with a 95\% confidence interval. Secondary outcomes were analyzed as described in the statistical analysis plan (see supplementary material). No multiplicity adjustments were implemented for the secondary analyses. Procedures planned for addressing missing data and subgroup analyses are described in the statistical analysis plan (see supplementary appendix). Forest plots were used to display point estimates and confidence intervals across subgroups with interaction tests used to assess effect modification.

The effect-modifying role of antibody content on the primary outcome was assessed via logistic regression controlling for the blood supplier, treatment, and the antibody marker. Antibody markers were log-transformed, centered and then divided by the corresponding standard deviation before being entered into logistic regression models (see statistical analysis plan, supplementary appendix). A multivariate logistic regression model was then fitted adjusting for all four markers. Generalized additive models were used to examine the joint effect of each pair of serologic markers on the primary outcome. ${ }^{20}$

The results from CONCOR-1 were subsequently included in a meta-analysis based on the May $20^{\text {th }}$ 2021 update of the Cochrane systematic review ${ }^{8}$ and known randomised trials published since comparing convalescent plasma to placebo or standard care in patients with COVID-19. These were divided based on whether they used plasma with high antibody titre or not. For each trial, we compared the observed number of deaths at 30 days (or closest available time point prior to a crossover, if applicable) among patients allocated to convalescent plasma or the control group. Summary estimates for relative risk with 95\% confidence interval were calculated using randomeffects meta-analysis to account for variation in effect size amongst studies. Heterogeneity was quantified using inconsistency index $\left(\mathrm{I}^{2}\right)$ and p-values from the chi-square test for homogeneity. 
medRxiv preprint doi: https://doi.org/10.1101/2021.06.29.21259427; this version posted July 3, 2021. The copyright holder for this preprint (which was not certified by peer review) is the author/funder, who has granted medRxiv a license to display the preprint in perpetuity. It is made available under a CC-BY-NC-ND 4.0 International license .

With a 2:1 randomization ratio, 1200 patients (800 in the convalescent plasma group, and 400 in the standard of care group) were needed to provide $80 \%$ power to detect a relative risk reduction of 25\% with convalescent plasma for the primary outcome with a 30\% event rate under standard of care, based on a two-sided test at the $5 \%$ significance level. An interim analysis by a biostatistician unblinded to the allocation of the intervention was planned for when the primary outcome was available for $50 \%$ of the target sample. An O'Brien-Fleming stopping rule was employed ${ }^{21}$ to control the overall type-I error rate at 5\%. Conditional power was used to guide futility decisions with the nominal threshold of $20 \%$ to justify early stopping. 


\section{Results}

\section{Patients}

The trial was stopped at the planned interim analysis because the conditional power estimate was $1.6 \%$ (below the stopping criterion of 20\%). Between May $14^{\text {th }} 2020$ and January 29 ${ }^{\text {th }} 2021,940$ patients were randomized (Figure 1, eTable 1). Seventeen patients were lost to follow up between discharge and day 30 and two withdrew consent. Baseline demographics were balanced between groups for all study populations (Tables 1, eTable 2, 3). Median age was 69 years, with 59\% male and the median time from the onset of any COVID-19 symptom was 8 days (interquartile range, 5 to 10$)$. The majority of participants (84.0\%) were receiving systemic corticosteroids at the time of enrolment.

\section{Primary Outcome}

In the intention-to-treat population (n=921), intubation or death occurred in 199 (32.4\%) of 614 patients in the convalescent plasma group and 86 (28.0\%) of 307 in the standard of care group [relative risk (RR) 1.16; 95\% confidence interval (CI) 0.94 to 1.43; $\mathrm{p}=0.18$ ] (Table 2). The time to intubation or death was not significantly different between groups (eFigure 2). In the per-protocol analysis ( $\mathrm{n}=851)$, intubation or death occurred in 167 (30.5\%) of 548 patients in the convalescent plasma group and 85 (28.1\%) of 303 patients in the standard of care group (RR=1.09; 95\% CI 0.87 to $1.35 ; \mathrm{p}=0.46$ ) (eTable 4).

\section{Secondary Efficacy Outcomes and Subgroup Analyses}

Secondary outcomes for the intention-to-treat population are provided in Table 2. There were no differences in mortality or intubation or other secondary efficacy outcomes. Similarly, in the perprotocol analysis there were no differences in the secondary efficacy outcomes (eTable 4). No 
medRxiv preprint doi: https://doi.org/10.1101/2021.06.29.21259427; this version posted July 3, 2021. The copyright holder for this preprint (which was not certified by peer review) is the author/funder, who has granted medRxiv a license to display the preprint in perpetuity. It is made available under a CC-BY-NC-ND 4.0 International license .

significant differences were observed in any of the pre-specified subgroups for both the intentionto-treat (Figure 2) and per-protocol populations (eFigure 1).

\section{Safety}

Serious adverse events occurred in 205 (33.4\%) of 614 patients in the convalescent plasma arm compared to 81 (26.4\%) of 307 patients in the standard of care arm for the intention-to-treat population $(\mathrm{RR}=1.27,95 \%$ CI 1.02 to $1.57, \mathrm{p}=0.034$; eTable 5). Most of these events were worsening hypoxemia and respiratory failure. Transfusion related complications were recorded in 35 (5.7\%) of 614 patients in the convalescent plasma group (eTable 7). Of the 35 reactions, 4 were life-threatening (2 transfusion-associated circulatory overload, 1 possible transfusion-related acute lung injury, 1 transfusion-associated dyspnea), and none were fatal. Thirteen of the 35 reactions were classified as transfusion-associated dyspnea. Two patients underwent serological investigation for transfusion-related acute lung injury (both negative).

\section{Effect-modifying role of the Antibodies in Convalescent Plasma}

The distributions of antibodies in convalescent plasma units varied by blood supplier (Figure 3, eTable 9); therefore, antibody analyses controlled for supplier to address possible confounding. Transfusion of convalescent plasma with average (log-transformed) levels of ADCC yielded an odds ratio of $1.16(95 \% \mathrm{CI}: 0.85,1.57)$ for the primary outcome relative to standard of care. Each one unit increase in the standardized log transformed ADCC was associated with a $24 \%$ reduction in the odds ratio of the treatment effect $(\mathrm{OR}=0.76,95 \% \mathrm{CI}$ : 0.62-0.92) (Figure 3, eTable 10). This effect modifying role was also significant for the neutralization test (OR=0.77; 0.63-0.94), but not for anti-RBD ELISA (OR=0.84; 0.69-1.03), or IgG against the full transmembrane Spike $(\mathrm{OR}=1.01 ; 0.82-1.23)$ 
medRxiv preprint doi: https://doi.org/10.1101/2021.06.29.21259427; this version posted July 3, 2021. The copyright holder for this preprint (which was not certified by peer review) is the author/funder, who has granted medRxiv a license to display the preprint in perpetuity. It is made available under a CC-BY-NC-ND 4.0 International license.

When all four serologic markers were included in the multivariate model, each one unit increase in the standardized log transformed anti-Spike IgG marker was associated with a 53\% increase in the odds ratio for the deleterious effect of convalescent plasma on the primary outcome $(\mathrm{OR}=1.53$, 95\% CI 1.14-2.05); increases in ADCC and neutralization independently improved the effect of $\mathrm{CCP}(\mathrm{OR}=0.66 ; 0.50-0.87$ and $\mathrm{OR}=0.74 ; 0.57-0.95$, respectively) while levels of anti-RBD antibodies had no effect-modifying role (OR=1.02; 0.76, 1.38) (eTable 10). There was no evidence of significant interaction between the four serologic measures in the general additive model (Figure 3, eTable 10).

\section{Meta-analysis}

Of the fifteen other reported randomised trials, eleven used only high-titre plasma ${ }^{5,7,22-30}$ and four applied less stringent plasma selection criteria allowing for variable plasma titres ${ }^{6,31-33}$. Including the results from CONCOR-1, a total of 15,301 patients were included in the trials using high-titre plasma and 968 participated in a trial applying less stringent criteria. The summary estimates for the relative risk of mortality in high-titre plasma trials was 0.97 (95\% CI $0.92-1.02$ ), compared to 1.25 (95\% CI 0.92-1.69) in trials using unselected convalescent plasma (Figure 4). 
medRxiv preprint doi: https://doi.org/10.1101/2021.06.29.21259427; this version posted July 3, 2021. The copyright holder for this preprint (which was not certified by peer review) is the author/funder, who has granted medRxiv a license to display the preprint in perpetuity. It is made available under a CC-BY-NC-ND 4.0 International license .

\section{Discussion}

The CONCOR-1 trial found that the use of convalescent plasma for the treatment of hospitalized patients with COVID-19 did not reduce the risk of intubation or death at 30 days. Patients in the convalescent plasma arm experienced more serious adverse events. Convalescent plasma was not associated with an improvement in any of the secondary efficacy outcomes or in any of the subgroups. These results are consistent with the RECOVERY trial and a recent Cochrane metaanalysis. ${ }^{8,10}$ A major additional contribution of our study comes from the study of immunologic markers, which suggest that the antibody profile significantly modified the effect of convalescent plasma compared to standard of care.

The RECOVERY trial showed that transfusion of high-titer plasma was no better than standard of care in prevention of key outcomes. ${ }^{10}$ The US National Registry report showed that high antibody level plasma was associated with a 34\% relative risk reduction in mortality compared to low antibody level plasma. ${ }^{9}$ Our assessment of the role of antibody profile on the clinical effect relative to standard of care is aligned with both of these conclusions. In the RECOVERY trial, plasma with a commercial ELISA cut-off corresponding to a neutralizing antibody titer of 100 or greater was used and the mortality rate ratio compared with standard of care was 1.00 (95\% CI 0.93-1.07). ${ }^{10}$ In our trial, plasma from one of the blood suppliers (blood supplier 1) that used a similar antibody threshold (neutralizing antibody titer of 160 of greater) was associated with a similar effect size [OR 0.95 (95\% CI 0.73-1.25)] (Figure 3). In contrast, the US National Registry study, which lacked a control group, reported that plasma containing high antibody levels (Ortho Vitros IgG anti-Spike subunit 1 , which contains the receptor binding domain (RBD), signal to cut-off ratio > 18.45) was associated with a 34\% reduction in mortality compared to plasma containing low antibody levels (signal to cut-off ratio < 4.62). ${ }^{9}$ In our regression model (eTable 10), plasma with anti-RBD ELISA values corresponding to this low antibody cut-off (Figure 3) would have a predicted OR of 
medRxiv preprint doi: https://doi.org/10.1101/2021.06.29.21259427; this version posted July 3, 2021. The copyright holder for this preprint (which was not certified by peer review) is the author/funder, who has granted medRxiv a license to display the preprint in perpetuity.

It is made available under a CC-BY-NC-ND 4.0 International license .

1.49 compared with controls (95\% CI: 0.98-2.29), while plasma with the corresponding high antibody cut-off would have a predicted OR of 0.91 (95\% CI: 0.60-1.40), representing a 38\% relative risk reduction. Thus, the $34 \%$ relative risk reduction observed by US National Registry ${ }^{9}$ could be explained by increased mortality with low antibody plasma, rather than improved mortality with high antibody plasma.

This conclusion is corroborated by the meta-analysis of previous trials based on plasma selection strategy. While the vast majority of patients included in convalescent plasma trials received with high-titre plasma, most patients treated outside of clinical trials did not, including many of those who received plasma by the current FDA requirements (Ortho Vitros $\geq 9.5$ ). Only $20 \%$ of convalescent plasma included in the US National registry was considered high-titre ${ }^{9}$. In our study blood supplier 3 used the same plasma as the one used in clinic as part of the EUA, and in our subgroup analysis convalescent plasma from this blood supplier was associated with worse clinical outcomes (OR=1.89, 95\%CI $1.05-3.43)$.

The antibody content is critical in determining the potency and potential harm of passive antibody therapy. Convalescent plasma demonstrating high levels of viral neutralization and high levels of Fc-mediated function were independently associated with a reduced risk for intubation or death. The importance of Fc-mediated function is in line with the known functional determinants of the anti-SARS-CoV-2 humoral response. In animal models of COVID-19, mutation of monoclonal antibodies leading to loss of Fc-mediated function, but sparing the neutralizing function, abrogated the protective effect of the antibody. ${ }^{34-37}$ In cohort studies of severe COVID-19, low Fc-mediated function but not neutralization was associated with mortality. ${ }^{38,39}$ 
medRxiv preprint doi: https://doi.org/10.1101/2021.06.29.21259427; this version posted July 3, 2021. The copyright holder for this preprint (which was not certified by peer review) is the author/funder, who has granted medRxiv a license to display the preprint in perpetuity. It is made available under a CC-BY-NC-ND 4.0 International license .

In contrast, high levels of IgG antibodies against the full transmembrane Spike protein measured by flow cytometry (which are distinct from commercial assays for IgG against Spike subunit 1) were associated with an increased risk of intubation or death after controlling for other antibody markers, suggesting that the transfusion of convalescent plasma containing non-functional anti-SARS-CoV2 antibodies may be harmful. Antibody Fc-mediated function is dependent on the ability to aggregate and crosslink Fc receptors on target cells. This process can be disrupted by competition from other antibodies with low or absent Fc function. ${ }^{40}$ Similar observations were made during HIV vaccine trials, where the development of IgA antibodies against the virus envelope paradoxically increased the risk of infection due to competition with IgG, ${ }^{41,42}$ and in animal models of passive immunization where transfer of antibodies could be deleterious to the host. ${ }^{43}$

One positive clinical trial in mild disease $(n=160)$ found that high-titer convalescent plasma administered within 72 hours of the onset of mild COVID-19 symptoms improved clinical outcomes compared with placebo in an elderly outpatient population. ${ }^{25}$ Furthermore, in a Bayesian re-analysis of the RECOVERY trial, the subgroup of patients who had not yet developed antiSARS-CoV-2 antibodies appeared to benefit from convalescent plasma. ${ }^{44}$ The C3PO trial, which also assessed early treatment with high-titer plasma in high-risk patients, was stopped prematurely for futility after enrolling 511 of 900 planned participants (NCT04355767). In our trial, the median time from the onset of symptoms was 8 days; however, we did not observe a difference in the primary outcome in the subgroup of patients who received convalescent plasma within three days from diagnosis.

The frequency of serious adverse events was higher in the convalescent plasma group compared with the standard of care group (33.4\% vs. 26.4\%; RR=1.27, 95\% CI 1.02-1.57). Most of these events were caused by worsening hypoxemia and respiratory failure occurring throughout the 30 
medRxiv preprint doi: https://doi.org/10.1101/2021.06.29.21259427; this version posted July 3, 2021. The copyright holder for this preprint (which was not certified by peer review) is the author/funder, who has granted medRxiv a license to display the preprint in perpetuity. It is made available under a CC-BY-NC-ND 4.0 International license .

day follow up period. This frequency is consistent with the recent Cochrane review which reported an OR of 1.24 (95\% CI 0.81-1.90) for serious adverse events. ${ }^{8}$ The frequency of transfusionassociated dyspnea and transfusion-associated circulatory overload were $2.1 \%$ and $0.8 \%$, respectively, similar to other studies of non-convalescent plasma. ${ }^{45}$ The rates of transfusion reactions in CONCOR-1 were higher than what was reported in the RECOVERY trial, where transfusion reactions were reported in $13(0.22 \%)$ of 5795 patients. ${ }^{10}$ CONCOR-1 site investigators included many transfusion medicine specialists and the open-label design may have encouraged reporting. However, the rate of serious transfusion-related AEs was low (4 of 614 (0.65\%) convalescent plasma treated patients) and thus, does not explain the difference in serious adverse events between groups.

CONCOR-1 was a novel randomized trial designed to examine the effect of convalescent plasma versus standard of care for the primary composite outcome of intubation of death, with a capacity to explore the immunological profile of convalescent plasma and its impact on the effect of convalescent plasma. The trial involved four blood suppliers that provided local convalescent plasma units based on different antibody criteria. As a result, plasma units with a wide distribution of antibody content were included, and comprehensive antibody testing using both quantitative and functional assays provided a detailed description of the plasma product. The open-label design represents a limitation of this study as knowledge of the treatment group could influence the decision to intubate, report adverse events, or administer other treatments. The antibody profile of the recipient was unavailable at the time of this analysis. In future work we will investigate the value of convalescent plasma in patients without a detectable humoral immune response. In addition, other antibody isotypes (IgM and IgA) and IgG subclasses should be evaluated in future studies to determine their effect on clinical outcomes. 
medRxiv preprint doi: https://doi.org/10.1101/2021.06.29.21259427; this version posted July 3, 2021. The copyright holder for this preprint (which was not certified by peer review) is the author/funder, who has granted medRxiv a license to display the preprint in perpetuity.

It is made available under a CC-BY-NC-ND 4.0 International license .

In summary, the CONCOR-1 trial did not demonstrate a difference in the frequency of intubation or death at 30 days with convalescent plasma or standard of care in hospitalized patients with COVID-19 respiratory illness. The antibody content had a significant effect-modifying role for the impact of convalescent plasma on the primary outcome. The lack of benefit and the potential concern of harm cautions against the unrestricted use of convalescent plasma for hospitalized patients with COVID-19. 
medRxiv preprint doi: https://doi.org/10.1101/2021.06.29.21259427; this version posted July 3, 2021. The copyright holder for this preprint (which was not certified by peer review) is the author/funder, who has granted medRxiv a license to display the preprint in perpetuity. It is made available under a CC-BY-NC-ND 4.0 International license .

\section{Contributors}

PB, JC, EJ, RCo, NMH, AT, MPZ, GBB, RB, KCL, RCa, MC, ND, DVD, DAF, AM, NR, DCS, LS, NS, AFT, RZ, AF, DMA were involved in study conceptualization, funding acquisition and methodology. PB, JC, RCo, GBB, RB, HW, AF, NL, YL and DMA developed the methodology for antibody analyses. PB, JC, NMH, AT, MPZ, GBB, LA, RB, MC, MMC, ND, DVD, JD, DAF, CG, MJG, AM, NR, BSS, DCS, LS, NS, AFT, HW, RZ, AF, DMA participated in the investigations. PB, JC, EJ, NMH, AT, MPZ, LA, RB, MMC, DVD, CG, MJG, NR, BSS and DMA were responsible for project administration. PB, JC, EJ, RC, GBB, RB, DVD, NL, YL, HW and DMA were involved in data curation. PB, JC, RC, NL, YL and DMA were responsible for formal analyses and data visualisation. PB, JC, YL, and DMA have verified the underlying data. PB, JC, RC and DMA drafted the original manuscript. All members of the writing committee reviewed and edited the final manuscript.

\section{Role of the funding source}

Funding for the study was provided by Canadian Institutes of Health Research - COVID-19 May 2020 Rapid Research Funding Opportunity- Operating Grant; Ontario COVID-19 Rapid Research Fund; Toronto COVID-19 Action Initiative 2020 (University of Toronto); University Health Network Emergent Access Innovation Fund; University Health Academic Health Science Centre Alternative Funding Plan (Sunnybrook Health Sciences Centre); Ministère de l'Économie et de l'Innovation (Québec); Saskatchewan Ministry of Health; University of Alberta Hospital Foundation; Alberta Health Services COVID-19 Foundation Competition; Sunnybrook Health Sciences Centre Foundation; Fondations CHU Ste-Justine; Fondation du CHUM; The Ottawa Hospital Academic Medical Organization; The Ottawa Hospital Foundation COVID-19 Research Fund; Sinai Health System Foundation and McMaster University. These did not have any role in the writing of the manuscript or the decision to submit it for publication. The authors did not 
medRxiv preprint doi: https://doi.org/10.1101/2021.06.29.21259427; this version posted July 3, 2021. The copyright holder for this preprint (which was not certified by peer review) is the author/funder, who has granted medRxiv a license to display the preprint in perpetuity. It is made available under a CC-BY-NC-ND 4.0 International license .

receive payments from any pharmaceutical company or other agency to write this article. All the authors had full access to the full data in the study and accept responsibility to submit for publication.

\section{Declaration of Interests}

PB reports payments to his institution from Canadian Institutes of Health Research, Ministère de l’économie et de l’innovation du Québec, Fondation du CHU Sainte-Justine, Fondation du CHUM, and Fonds de Recherche du Québec en Santé; JC reports research grants from Canadian Institutes of Health Research, University of Toronto, Sunnybrook Health Sciences Centre, and Canadian Blood Services; NMH reports research project funding unrelated to this study from Canadian Institutes of Health Research and Canadian Blood Services, honorarium for educational events unrelated to this study from CSL Behring Canada, and participation on a Data Safety Monitoring Board or Advisory Board for Canadian Blood Services (Scientific Advisory Committee); MPZ reports consulting fees from Canadian Blood Services in her role as a Medical Officer but receives no direct benefit from the study results; GBB reports a grant from Canadian Institutes of Health Research for Masters students; MMC reports consulting fees from Octapharma, participation in a data safety monitoring board or advisory board for Cerus and Haemonetics, and receipt of equipment, materials, drugs, medical writing, gifts or other services by her institution from Cerus; ND reports grants from AFP Innovation Fund Award Sunnybrook Health Sciences Centre, and University of Toronto; MJG reports payments to his institution from Regeneron, consulting fees from Regeneron and ReAlta Life Sciences, and participation on a Data Safety Monitoring Board or Advisory Board for Enzychem and Sobi; BSS reports employment by New York Blood Centre (but receiving no direct benefit from study participation); LS reports a leadership or fiduciary role in other board, society, committee or advocacy group, paid or unpaid (Member of the Ontario Bioethics Table for COVID-19); NS reports payment to her 
medRxiv preprint doi: https://doi.org/10.1101/2021.06.29.21259427; this version posted July 3, 2021. The copyright holder for this preprint (which was not certified by peer review) is the author/funder, who has granted medRxiv a license to display the preprint in perpetuity.

It is made available under a CC-BY-NC-ND 4.0 International license .

institution from the MSH Foundation for CONCOR; AF reports funding from Fondation du

CHUM, Ministère de l'économie et de l’Innovation du Québec, and Canadian Institutes of Health

Research. All other authors declare no competing interests.

\section{Data Sharing}

De-identified individual patient data with the data dictionary that underlie the reported results will be made available upon request if approved by the CONCOR-1 Steering Committee. Proposals for access should be sent to arnold@mcmaster.ca. The protocol and statistical analysis plan are available online. 
medRxiv preprint doi: https://doi.org/10.1101/2021.06.29.21259427; this version posted July 3, 2021. The copyright holder for this preprint (which was not certified by peer review) is the author/funder, who has granted medRxiv a license to display the preprint in perpetuity.

\section{References}

1. Seow J, Graham C, Merrick B, et al. Longitudinal observation and decline of neutralizing antibody responses in the three months following SARS-CoV-2 infection in humans. Nat Microbiol. Dec 2020;5(12):1598-1607. doi:10.1038/s41564-020-00813-8

2. Devasenapathy N, Ye Z, Loeb M, et al. Efficacy and safety of convalescent plasma for severe COVID-19 based on evidence in other severe respiratory viral infections: a systematic review and meta-analysis. CMAJ. Jul 6 2020;192(27):E745-E755. doi:10.1503/cmaj.200642 3. Wood EM, Estcourt LJ, McQuilten ZK. How should we use convalescent plasma therapies for the management of COVID-19? Blood. Mar 25 2021;137(12):1573-1581. doi:10.1182/blood.2020008903

4. Blackall D, Wulff S, Roettger T, et al. Rapid establishment of a COVID-19 convalescent plasma program in a regional health care delivery network. Transfusion. Oct 2020;60(10):22032209. doi:10.1111/trf.16026

5. Simonovich VA, Burgos Pratx LD, Scibona P, et al. A Randomized Trial of Convalescent Plasma in Covid-19 Severe Pneumonia. N Engl J Med. Feb 18 2021;384(7):619-629. doi:10.1056/NEJMoa2031304

6. Agarwal A, Mukherjee A, Kumar G, et al. Convalescent plasma in the management of moderate covid-19 in adults in India: open label phase II multicentre randomised controlled trial (PLACID Trial). BMJ. Oct 22 2020;371:m3939. doi:10.1136/bmj.m3939

7. Li L, Zhang W, Hu Y, et al. Effect of Convalescent Plasma Therapy on Time to Clinical Improvement in Patients With Severe and Life-threatening COVID-19: A Randomized Clinical Trial. JAMA. Aug 4 2020;324(5):460-470. doi:10.1001/jama.2020.10044

8. Piechotta V, Iannizzi C, Chai KL, et al. Convalescent plasma or hyperimmune immunoglobulin for people with COVID-19: a living systematic review. Cochrane Database Syst Rev. May 20 2021;5:CD013600. doi:10.1002/14651858.CD013600.pub4

9. Joyner MJ, Carter RE, Senefeld JW, et al. Convalescent Plasma Antibody Levels and the Risk of Death from Covid-19. N Engl J Med. Mar 18 2021;384(11):1015-1027.

doi:10.1056/NEJMoa2031893

10. The RECOVERY Collaborative Group PWH, Lise Estcourt, Leon Peto, et al. Convalescent plasma in patients admitted to hospital with COVID-19 (RECOVERY): a randomised, controlled, open-label, platform trial. Lancet 2021; May 14, 2021; https://doiorg/101016/S01406736(21)00897-7. 2021;

11. Begin P, Callum J, Heddle NM, et al. Convalescent plasma for adults with acute COVID-19 respiratory illness (CONCOR-1): study protocol for an international, multicentre, randomized, open-label trial. Trials. May 4 2021;22(1):323. doi:10.1186/s13063-021-05235-3

12. Budhai A, Wu AA, Hall L, et al. How did we rapidly implement a convalescent plasma program? Transfusion. Jul 2020;60(7):1348-1355. doi:10.1111/trf.15910

13. Beaudoin-Bussieres G, Laumaea A, Anand SP, et al. Decline of Humoral Responses against SARS-CoV-2 Spike in Convalescent Individuals. mBio. Oct 16 2020;11(5)doi:10.1128/mBio.02590-20

14. Perreault J, Tremblay T, Fournier MJ, et al. Waning of SARS-CoV-2 RBD antibodies in longitudinal convalescent plasma samples within 4 months after symptom onset. Blood. Nov 26 2020;136(22):2588-2591. doi:10.1182/blood.2020008367

15. Abe KT, Li Z, Samson R, et al. A simple protein-based surrogate neutralization assay for SARS-CoV-2. JCI Insight. Oct 2 2020;5(19)doi:10.1172/jci.insight.142362

16. Mendoza EJ, Manguiat K, Wood H, Drebot M. Two Detailed Plaque Assay Protocols for the Quantification of Infectious SARS-CoV-2. Curr Protoc Microbiol. Jun 2020;57(1):ecpmc105. doi:10.1002/cpmc.105 
medRxiv preprint doi: https://doi.org/10.1101/2021.06.29.21259427; this version posted July 3, 2021. The copyright holder for this preprint (which was not certified by peer review) is the author/funder, who has granted medRxiv a license to display the preprint in perpetuity. It is made available under a CC-BY-NC-ND 4.0 International license .

17. Anand SP, Prevost J, Richard J, et al. High-throughput detection of antibodies targeting the SARS-CoV-2 Spike in longitudinal convalescent plasma samples. Transfusion. Feb 18 2021;doi:10.1111/trf.16318

18. Tauzin A NM, Benlarbi M, et al. A single BNT162b2 mRNA dose elicits antibodies with Fc-mediated effector functions and boost pre-existing humoral and T cell responses. bioRxiv 20210318435972; doi: https://doiorg/101101/20210318435972.

19. Anand SP, Prevost J, Nayrac M, et al. Longitudinal analysis of humoral immunity against SARS-CoV-2 Spike in convalescent individuals up to eight months post-symptom onset. Cell Rep Med. May 5 2021:100290. doi:10.1016/j.xcrm.2021.100290

20. SN W. Generalized Additive Models. An Introduction with R. Second Edition. Published by Taylor and Fracis Group (Boco Raton). 2017;doi:https://doi.org/10.1201/9781315370279

21. O'Brien PC, Fleming TR. A multiple testing procedure for clinical trials. Biometrics. Sep 1979;35(3):549-56.

22. Ray Y, Paul SR, Bandopadhyay P, et al. Clinical and immunological benefits of convalescent plasma therapy in severe COVID-19: insights from a single center open label randomised control trial. medRxiv. 2020:2020.11.25.20237883. doi:10.1101/2020.11.25.20237883

23. Gharbharan A, Jordans CCE, GeurtsvanKessel C, et al. Effects of potent neutralizing antibodies from convalescent plasma in patients hospitalized for severe SARS-CoV-2 infection. Nat Commun. May 27 2021;12(1):3189. doi:10.1038/s41467-021-23469-2

24. Group RC. Convalescent plasma in patients admitted to hospital with COVID-19 (RECOVERY): a randomised controlled, open-label, platform trial. Lancet. May 29 2021;397(10289):2049-2059. doi:10.1016/S0140-6736(21)00897-7

25. Libster R, Perez Marc G, Wappner D, et al. Early High-Titer Plasma Therapy to Prevent Severe Covid-19 in Older Adults. N Engl J Med. Feb 18 2021;384(7):610-618. doi:10.1056/NEJMoa2033700

26. O'Donnell MR, Grinsztejn B, Cummings MJ, et al. A randomized double-blind controlled trial of convalescent plasma in adults with severe COVID-19. J Clin Invest. May 11 2021;doi:10.1172/JCI150646

27. Avendaño-Solà C, Ramos-Martínez A, Muñez-Rubio E, et al. Convalescent Plasma for COVID-19: A multicenter, randomized clinical trial. medRxiv. 2020:2020.08.26.20182444. doi:10.1101/2020.08.26.20182444

28. Estcourt LJ. Convalescent Plasma in Critically ill Patients with Covid-19. medRxiv. 2021:2021.06.11.21258760. doi:10.1101/2021.06.11.21258760

29. Bennett-Guerrero E, Romeiser JL, Talbot LR, et al. Severe Acute Respiratory Syndrome Coronavirus 2 Convalescent Plasma Versus Standard Plasma in Coronavirus Disease 2019 Infected Hospitalized Patients in New York: A Double-Blind Randomized Trial*. Critical Care Medicine. 2021;49(7)

30. Körper S, Weiss M, Zickler D, et al. High Dose Convalescent Plasma in COVID-19: Results from the Randomized Trial CAPSID. medRxiv. 2021:2021.05.10.21256192. doi:10.1101/2021.05.10.21256192

31. AlQahtani M, Abdulrahman A, Almadani A, et al. Randomized controlled trial of convalescent plasma therapy against standard therapy in patients with severe COVID-19 disease. Sci Rep. May 11 2021;11(1):9927. doi:10.1038/s41598-021-89444-5

32. Hamdy Salman O, Ail Mohamed HS. Efficacy and safety of transfusing plasma from COVID-19 survivors to COVID-19 victims with severe illness. A double-blinded controlled preliminary study. Egyptian Journal of Anaesthesia. 2020/01/01 2020;36(1):264-272. doi:10.1080/11101849.2020.1842087

33. Bajpai M, Kumar S, Maheshwari A, et al. Efficacy of Convalescent Plasma Therapy compared to Fresh Frozen Plasma in Severely ill COVID-19 Patients: A Pilot Randomized Controlled Trial. medRxiv. 2020:2020.10.25.20219337. doi:10.1101/2020.10.25.20219337 
medRxiv preprint doi: https://doi.org/10.1101/2021.06.29.21259427; this version posted July 3, 2021. The copyright holder for this preprint (which was not certified by peer review) is the author/funder, who has granted medRxiv a license to display the preprint in perpetuity. It is made available under a CC-BY-NC-ND 4.0 International license .

34. Winkler ES, Gilchuk P, Yu J, et al. Human neutralizing antibodies against SARS-CoV-2 require intact Fc effector functions for optimal therapeutic protection. Cell. Apr 1 2021;184(7):1804-1820 e16. doi:10.1016/j.cell.2021.02.026

35. Suryadevara N, Shrihari S, Gilchuk P, et al. Neutralizing and protective human monoclonal antibodies recognizing the N-terminal domain of the SARS-CoV-2 spike protein. Cell. Apr 29 2021;184(9):2316-2331 e15. doi:10.1016/j.cell.2021.03.029

36. Ullah I, Prevost J, Ladinsky MS, et al. Live imaging of SARS-CoV-2 infection in mice reveals neutralizing antibodies require Fc function for optimal efficacy. bioRxiv. Mar 22 2021;doi:10.1101/2021.03.22.436337

37. Schafer A, Muecksch F, Lorenzi JCC, et al. Antibody potency, effector function, and combinations in protection and therapy for SARS-CoV-2 infection in vivo. J Exp Med. Mar 1 2021;218(3)doi:10.1084/jem.20201993

38. Brunet-Ratnasingham E AS, Gantner P, et al. Integrated immunovirological profiling validates plasma SARS-CoV-2 RNA as an early predictor of COVID-19 mortality. bioRxiv. 2021;March 20, 2021doi:https://doi.org/10.1101/2021.03.18.21253907

39. Zohar T, Loos C, Fischinger S, et al. Compromised Humoral Functional Evolution Tracks with SARS-CoV-2 Mortality. Cell. Dec 10 2020;183(6):1508-1519 e12. doi:10.1016/j.cell.2020.10.052

40. Casadevall A, Joyner MJ, Pirofski LA. Neutralizing Antibody LY-CoV555 for Outpatient Covid-19. N Engl J Med. Jan 14 2021;384(2):189. doi:10.1056/NEJMc2033787

41. Haynes BF, Gilbert PB, McElrath MJ, et al. Immune-correlates analysis of an HIV-1 vaccine efficacy trial. $N$ Engl J Med. Apr 5 2012;366(14):1275-86. doi:10.1056/NEJMoa1113425 42. Tomaras GD, Ferrari G, Shen X, et al. Vaccine-induced plasma IgA specific for the C1 region of the HIV-1 envelope blocks binding and effector function of IgG. Proc Natl Acad Sci U S A. May 28 2013;110(22):9019-24. doi:10.1073/pnas.1301456110

43. Taborda CP, Rivera J, Zaragoza O, Casadevall A. More is not necessarily better: prozonelike effects in passive immunization with IgG. J Immunol. Apr 1 2003;170(7):3621-30. doi:10.4049/jimmunol.170.7.3621

44. Hamilton F LT, Arnold D, Lilford R, Hemming K. Is convalescent plasma futile in COVID19? A Bayesian re-analysis of the RECOVERY randomised controlled trial. medRxiv 2021: 2021.04.01.21254679.

45. Narick C, Triulzi DJ, Yazer MH. Transfusion-associated circulatory overload after plasma transfusion. Transfusion. Jan 2012;52(1):160-5. doi:10.1111/j.1537-2995.2011.03247.x 


\section{Tables}

Table 1: Characteristics of the study population at baseline (excluding two patients who withdrew consent). Categorical data presented as number (percentage) and continuous variables as mean \pm standard deviation and median (interquartile range).

\begin{tabular}{|c|c|c|c|}
\hline Characteristic & $\begin{array}{l}\text { Convalescent Plasma } \\
\qquad \mathrm{n}=625\end{array}$ & $\begin{array}{l}\text { Standard of Care } \\
\qquad n=313\end{array}$ & $\begin{array}{l}\text { Overall } \\
n=938\end{array}$ \\
\hline Age - yr & $67.7 \pm 16.0 ; 69(58,80)$ & $67.1 \pm 14.8 ; 68(58,78)$ & $67.5 \pm 15.6 ; 69(58,79)$ \\
\hline$\geq 60$ years & 438 (70.1) & $218(69.6)$ & $656(69.9)$ \\
\hline \multicolumn{4}{|l|}{ Sex } \\
\hline Male & 369 (59.0) & 185 (59.1) & 554 (59.1) \\
\hline Pregnant at randomization & $4(0.6)$ & $1(0.3)$ & $5(0.5)$ \\
\hline \multicolumn{4}{|l|}{ Ethnicity } \\
\hline White & $305(48.8)$ & $153(48.9)$ & $458(48.8)$ \\
\hline Asian & $104(16.6)$ & $46(14.7)$ & $150(16.0)$ \\
\hline Hispanic or Latino & $34(5.4)$ & $9(2.9)$ & $43(4.6)$ \\
\hline Black & $25(4.0)$ & $11(3.5)$ & $36(3.8)$ \\
\hline Other & $38(6.1)$ & $28(8.9)$ & $66(7.0)$ \\
\hline Unknown & $119(19.0)$ & 66 (21.1) & 185 (19.7) \\
\hline \multicolumn{4}{|l|}{ ABO blood group } \\
\hline $\mathrm{O}$ & $270(43.2)$ & $113(36.1)$ & $383(40.8)$ \\
\hline A & $235(37.6)$ & $121(38.7)$ & 356 (38.0) \\
\hline B & $89(14.2)$ & $57(18.2)$ & $146(15.6)$ \\
\hline$A B$ & $31(5.0)$ & $22(7.0)$ & $53(5.7)$ \\
\hline $\mathrm{BMI}-\mathrm{kg} / \mathrm{m}^{2}$ & $30.0 \pm 7.5 ; 29(25,33)$ & $30.0 \pm 7.4 ; 29(25,33)$ & $30.0 \pm 7.4 ; 29(25,33)$ \\
\hline $\mathrm{BMI}<30$ & $256(41.0)$ & $123(39.3)$ & $379(40.4)$ \\
\hline
\end{tabular}




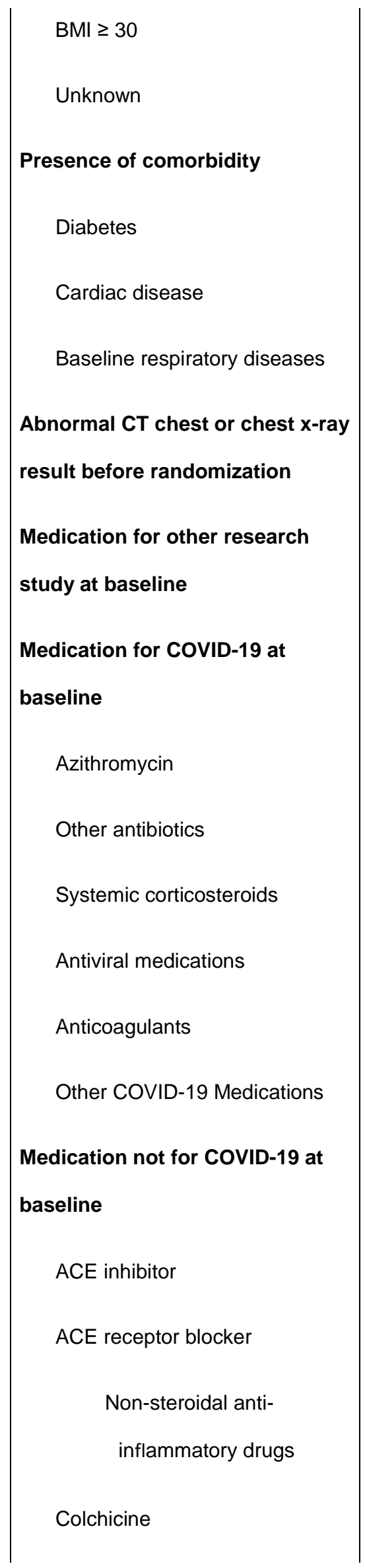

\begin{tabular}{|c|c|}
\hline 198 (31.7) & $102(32.6)$ \\
\hline $171(27.4)$ & 88 (28.1) \\
\hline 220 (35.2) & $108(34.5)$ \\
\hline 385 (61.6) & $197(62.9)$ \\
\hline 147 (23.5) & 79 (25.2) \\
\hline 563 (90.1) & $266(85.0)$ \\
\hline $53(8.5)$ & 41 (13.1) \\
\hline 279 (44.6) & $137(43.8)$ \\
\hline 405 (64.8) & $186(59.4)$ \\
\hline 496 (79.4) & $258(82.4)$ \\
\hline 165 (26.4) & $80(25.6)$ \\
\hline 355 (56.8) & $180(57.5)$ \\
\hline 79 (12.6) & $39(12.5)$ \\
\hline 85 (13.6) & $63(20.1)$ \\
\hline 77 (12.3) & $47(15.0)$ \\
\hline 77 (12.3) & 52 (16.6) \\
\hline $5(0.8)$ & $2(0.6)$ \\
\hline
\end{tabular}

300 (32.0)

259 (27.6)

328 (35.0)

$582(62.0)$

226 (24.1)

829 (88.4)

94 (10.0)

416 (44.3)

591 (63.0)

754 (80.4)

245 (26.1)

535 (57.0)

118 (12.6)

148 (15.8)

124 (13.2)

129 (13.8)

$7(0.7)$ 


\begin{tabular}{|c|c|c|c|}
\hline Systemic corticosteroids & $61(9.8)$ & $35(11.2)$ & $96(10.2)$ \\
\hline Inhaled corticosteroids & $84(13.4)$ & $42(13.4)$ & $126(13.4)$ \\
\hline Immunomodulatory agents & $22(3.5)$ & $18(5.8)$ & $40(4.3)$ \\
\hline Anticoagulants & $135(21.6)$ & $64(20.4)$ & $199(21.2)$ \\
\hline Oxygen status at baseline $\left(\mathrm{FiO}_{2}\right)$ & $49.5 \pm 25.2 ; 40(30,65)$ & $48.8 \pm 25.1 ; 40(30,60)$ & $49.3 \pm 25.2 ; 40(30,60)$ \\
\hline $\begin{array}{l}\text { Time from any symptom onset to } \\
\text { randomization (days) }\end{array}$ & $8.0 \pm 3.8 ; 8(5,10)$ & $7.8 \pm 3.4 ; 8(5,10)$ & $7.9 \pm 3.7 ; 8(5,10)$ \\
\hline $\begin{array}{l}\text { Time from Covid-19 diagnosis }{ }^{a} \text { to } \\
\text { randomization (days) }\end{array}$ & $4.9 \pm 3.6 ; 4(2,7)$ & $5.1 \pm 4.4 ; 4(2,7)$ & $5.0 \pm 3.9 ; 4(2,7)$ \\
\hline Enrolled in other clinical trials & $168(26.9)$ & $98(31.3)$ & $266(28.4)$ \\
\hline
\end{tabular}

aDay of positive Covid-19 test.

BMI: Body mass index; CT: Computed tomography; $\mathrm{FiO}_{2}$ : Fraction of inhaled oxygen. 
medRxiv preprint doi: https://doi.org/10.1101/2021.06.29.21259427; this version posted July 3, 2021. The copyright holder for this preprint (which was not certified by peer review) is the author/funder, who has granted medRxiv a license to display the preprint in perpetuity.

It is made available under a CC-BY-NC-ND 4.0 International license .

Table 2: Patient outcomes for the primary and secondary end points for the intention to treat population.

\begin{tabular}{|c|c|c|c|c|}
\hline & Population & $\begin{array}{l}\text { Convalescent } \\
\qquad \begin{array}{c}\text { Plasma } \\
n=614\end{array}\end{array}$ & $\begin{array}{c}\text { Standard of } \\
\text { Care } \\
\quad n=307\end{array}$ & Treatment effect ${ }^{a}$ \\
\hline $\begin{array}{l}\text { Intubation or death at day } 30(\mathrm{n} \text {, } \\
\%)\end{array}$ & $921^{b}$ & $199(32.4)$ & $86(28.0)$ & $\mathrm{RR}=1.16(0.94,1.43), \mathrm{p}=0.18$ \\
\hline $\begin{array}{l}\text { Time to Intubation or in-hospital } \\
\text { death by day } 30 \text { (days) }\end{array}$ & 921 & - & - & $H R=1.14(0.89,1.47), p=0.30$ \\
\hline $\begin{array}{l}\text { Ventilation-free days by day } 30 \\
\text { (days) }\end{array}$ & 921 & $23.4 \pm 10.4$ & $24.0 \pm 10.5$ & $\mathrm{MD}=-0.6(-2.1,0.7), \mathrm{p}=0.41$ \\
\hline Any death by day $30(n, \%)$ & 921 & $141(23.0)$ & $63(20.5)$ & $R R=1.12(0.86,1.46), p=0.40$ \\
\hline $\begin{array}{l}\text { Length of stay in ICU by day } 30 \\
\text { (days) }\end{array}$ & 921 & $4.3 \pm 7.9$ & $3.7 \pm 7.1$ & $\mathrm{MD}=0.7(-0.3,1.7), \mathrm{p}=0.22$ \\
\hline $\begin{array}{l}\text { Need for kidney replacement } \\
\text { therapy by day } 30(n, \%)\end{array}$ & $910^{c}$ & $10(1.6)$ & $6(2.0)$ & $\mathrm{RR}=0.83(0.31,2.27), \mathrm{p}=0.72$ \\
\hline $\begin{array}{l}\text { Serious adverse event by day } 30(\mathrm{n} \text {, } \\
\%)\end{array}$ & 921 & $205(33.4)$ & $81(26.4)$ & $R R=1.27(1.02,1.57), p=0.03$ \\
\hline Grade $\geq 3$ events (severe) & & $260(42.3)$ & $109(35.5)$ & $\mathrm{RR}=1.19(1.00,1.42), \mathrm{p}=0.05$ \\
\hline Grade $\geq 4$ events (life-threatening) & & $188(30.6)$ & $74(24.1)$ & $R R=1.27(1.01,1.60), p=0.04$ \\
\hline \multirow[t]{2}{*}{ Grade 5 events (fatal) } & & $141(23.0)$ & $63(20.5)$ & $R R=1.12(0.86,1.46), p=0.40$ \\
\hline & & $\begin{array}{c}\text { Convalescent } \\
\begin{array}{c}\text { Plasma } \\
\text { n=625 }\end{array}\end{array}$ & $\begin{array}{c}\text { Standard of } \\
\text { Care } \\
n=313\end{array}$ & \\
\hline In-hospital death by day 90 (n, \%) & $938^{d}$ & $156(25.0)$ & $69(22.0)$ & $R R=1.13(0.88,1.45), p=0.33$ \\
\hline Time to in-hospital death by day 90 & 938 & - & - & $\mathrm{HR}=1.02(0.76,1.35), p=0.91$ \\
\hline Length of stay in hospital by day 90 & 938 & - & - & $\mathrm{HR}=0.91(0.80,1.04), \mathrm{p}=0.18$ \\
\hline
\end{tabular}


medRxiv preprint doi: https://doi.org/10.1101/2021.06.29.21259427; this version posted July 3, 2021. The copyright holder for this preprint (which was not certified by peer review) is the author/funder, who has granted medRxiv a license to display the preprint in perpetuity.

\section{It is made available under a CC-BY-NC-ND 4.0 International license .}

${ }^{a}$ Relative Risk (RR, 95\% confidence interval), Hazard Ratio (HR, 95\% confidence interval) and Mean Difference (MD, with 95\%

CI based on robust bootstrap standard errors)

b17 patients discharged before day 30 and lost to follow-up at 30 days, and 2 withdrew consent before day 30, thus outcomes

collected at day 30 (primary outcome and some other secondary outcomes for day 30) were missing.

'Excluding 11 patients on chronic kidney replacement therapy at baseline

${ }^{\mathrm{d}}$ Excluding 2 patients that withdrew consent prior to outcome 
medRxiv preprint doi: https://doi.org/10.1101/2021.06.29.21259427; this version posted July 3, 2021. The copyright holder for this preprint (which was not certified by peer review) is the author/funder, who has granted medRxiv a license to display the preprint in perpetuity.

It is made available under a CC-BY-NC-ND 4.0 International license .

\section{Figures}

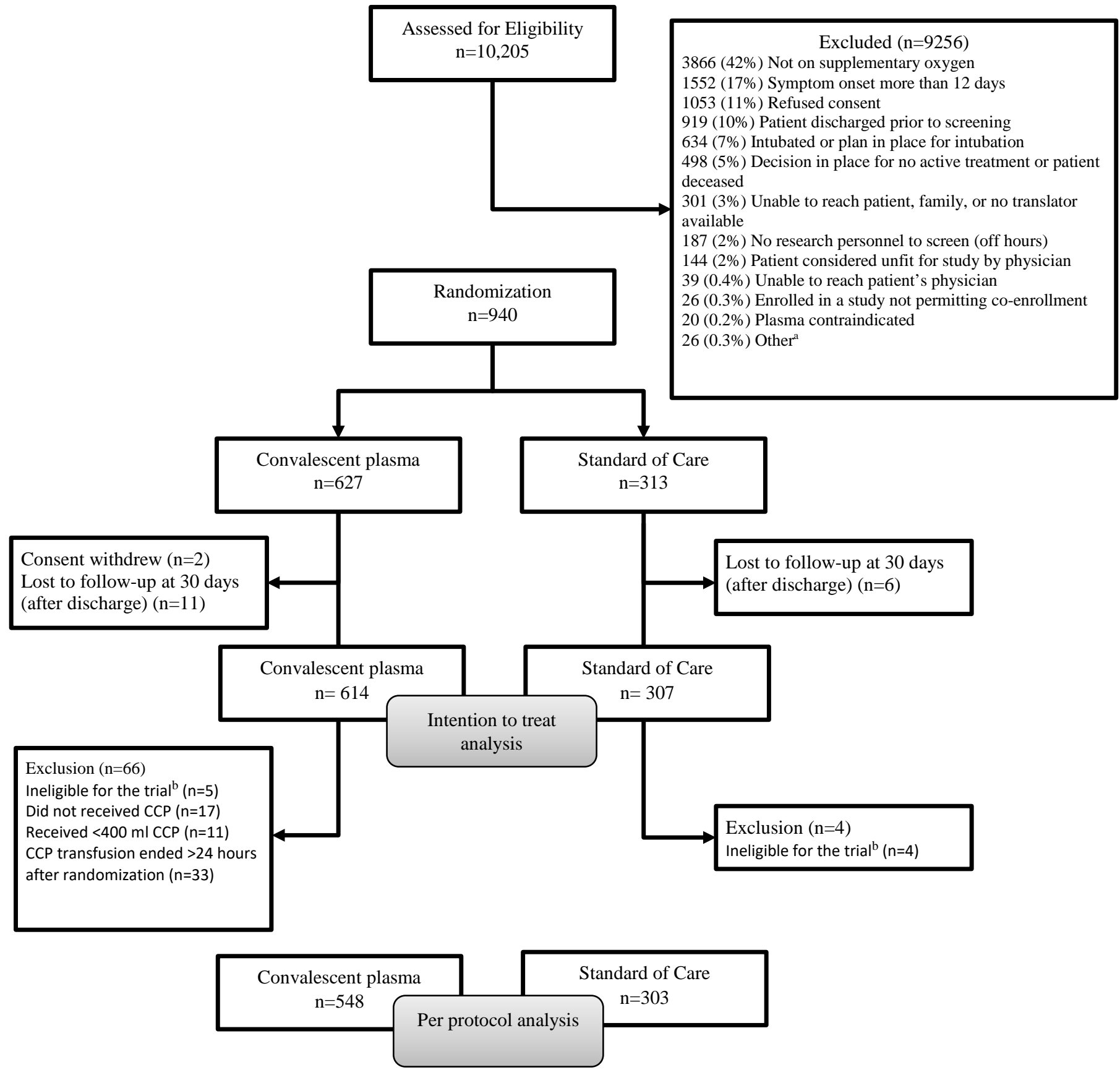

Figure 1: Enrolment, randomization, and follow-up. Patient flow in the CONCOR-1 Study detailing the intention-to-treat population, per-protocol analysis population, and excluded patients. ${ }^{\text {a }}$ Other $n=26$ : $<16$ years of age $(n=13),<18$ years of age $(n=5)$, ABO compatible plasma unavailable $(n=5)$, other $(n=3)$ ${ }^{\mathrm{b}}$ Includes not receiving supplemental oxygen at the time of randomization (but on oxygen at screening), and any symptoms onset $>12$ days prior to randomization for protocol version 5.0 or earlier. 
medRxiv preprint doi: https://doi.org/10.1101/2021.06.29.21259427; this version posted July 3, 2021. The copyright holder for this preprint (which was not certified by peer review) is the author/funder, who has granted medRxiv a license to display the preprint in perpetuity. It is made available under a CC-BY-NC-ND 4.0 International license.

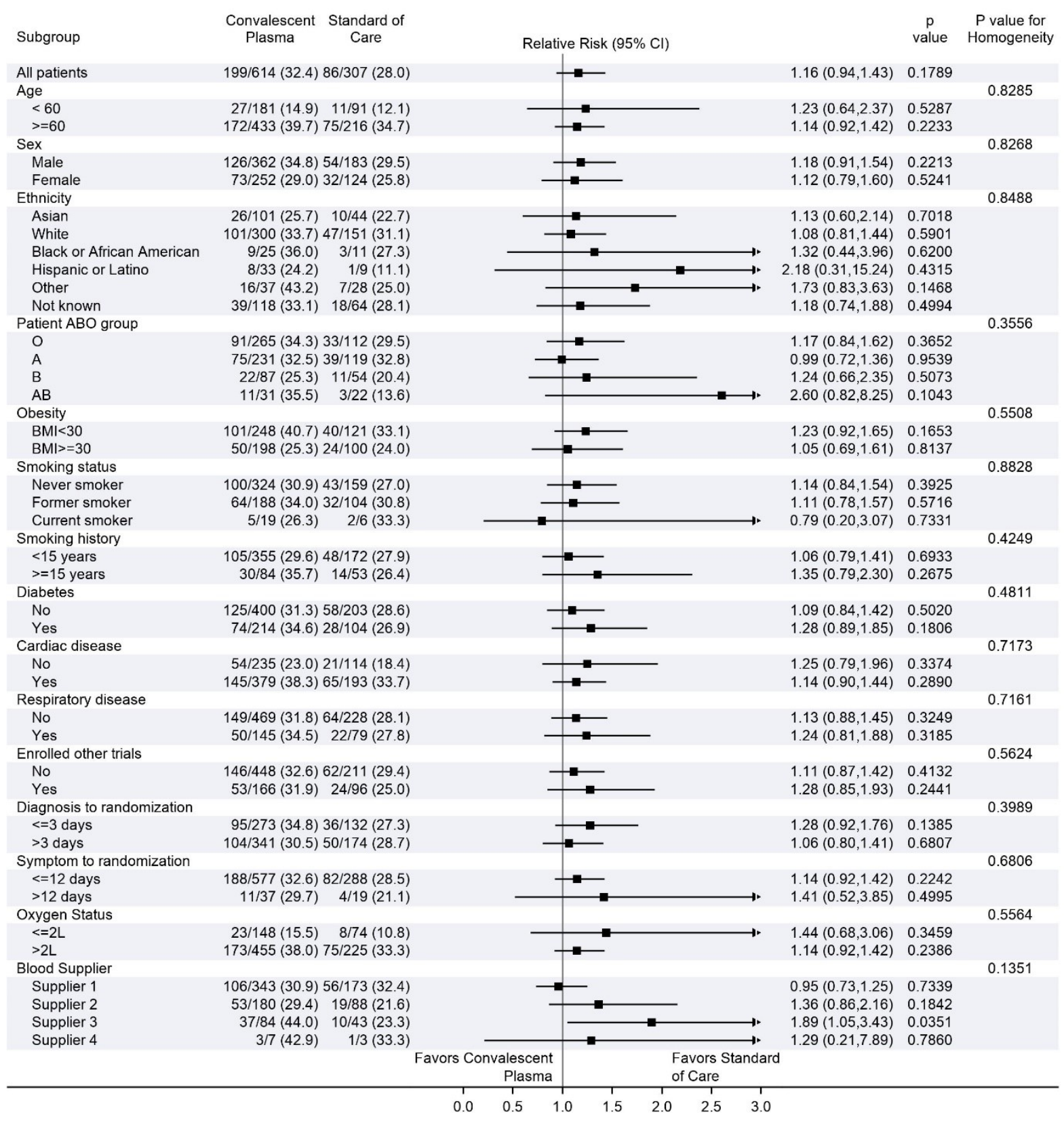

Figure 2: Subgroup analyses. Forest plots for the subgroup analyses for the intention to treat population. BMI: Body mass index. 
medRxiv preprint doi: https://doi.org/10.1101/2021.06.29.21259427; this version posted July 3, 2021. The copyright holder for this preprint (which was not certified by peer review) is the author/funder, who has granted medRxiv a license to display the preprint in perpetuity.

It is made available under a CC-BY-NC-ND 4.0 International license .

A

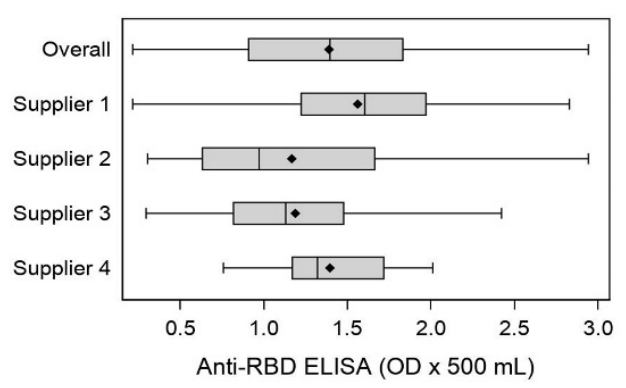

B
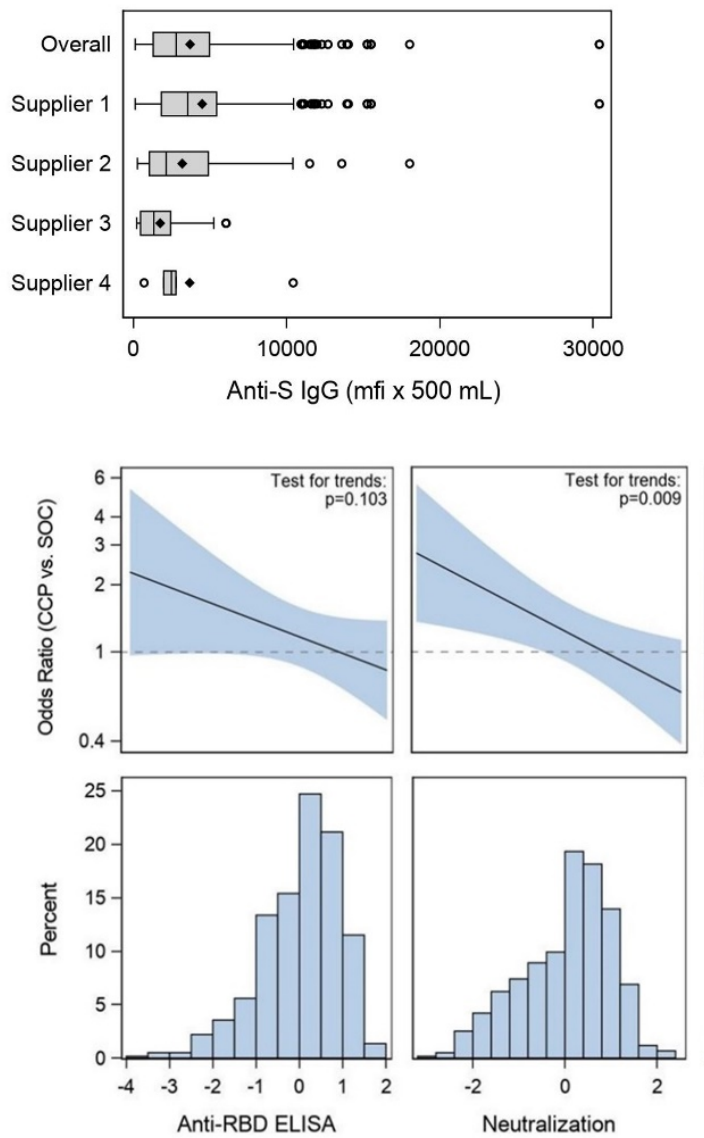

C

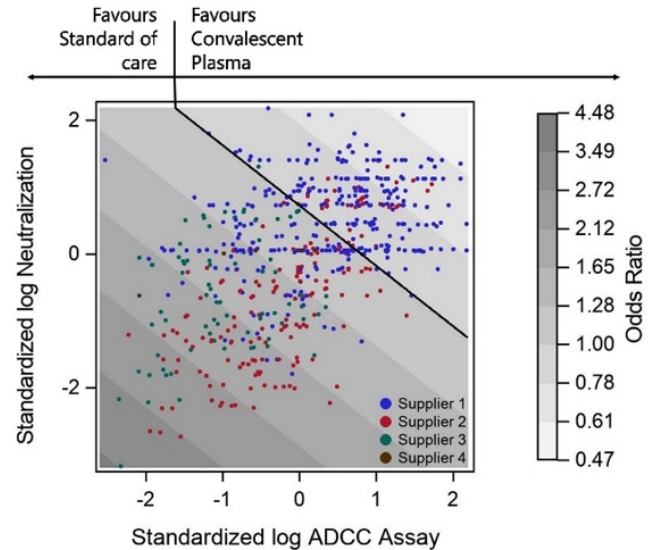

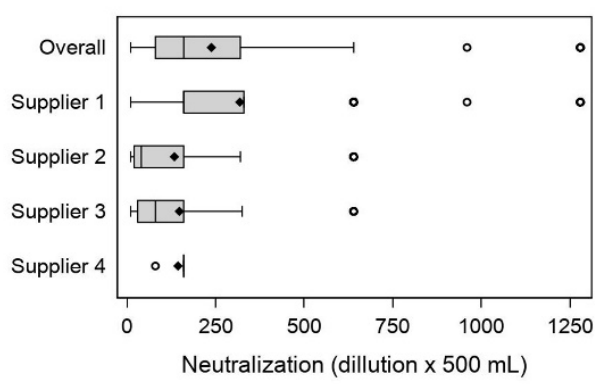
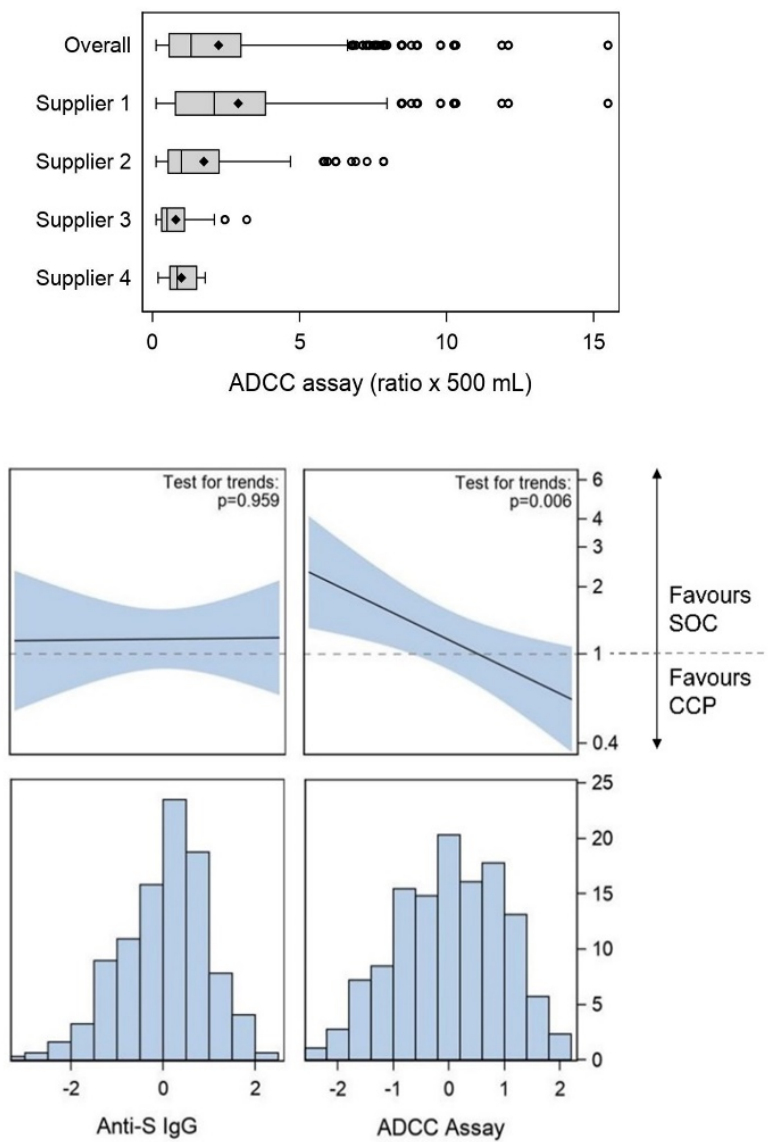

D

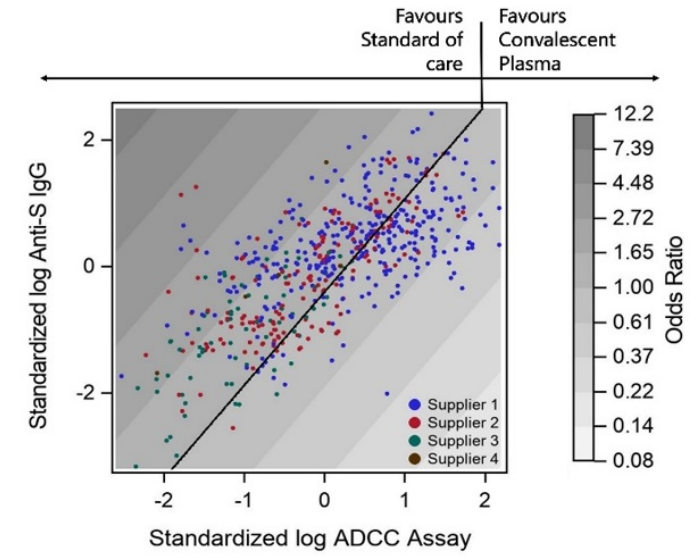


medRxiv preprint doi: https://doi.org/10.1101/2021.06.29.21259427; this version posted July 3, 2021. The copyright holder for this preprint (which was not certified by peer review) is the author/funder, who has granted medRxiv a license to display the preprint in perpetuity.

It is made available under a CC-BY-NC-ND 4.0 International license .

\section{Figure 3: The effect-modifying role of convalescent plasma antibody content for the primary outcome.}

Panel A presents boxplots of absolute antibody amounts transfused to the patients in the convalescent plasma (CCP) arm for each of the serologic marker, expressed as the product of their concentration measure and the volume. Center line, median; box limits, upper and lower quartiles; whiskers, 1.5x interquartile range; points, outliers. Panel B presents the effect-modifying role of CCP antibody content for the primary outcome for each antibody measure taken individually. The top row presents the plots of the trends in the convalescent plasma effect compared to standard of care (SOC) as a function of the marker value, along with 95\% confidence intervals, obtained from generalized additive models for each marker taken individually. Marker values are expressed as standard deviations of log values centered around the mean (standardized log). The horizontal dotted line represents a convalescent plasma with no effect $(\mathrm{OR}=1)$. The $\mathrm{p}$-values imbedded in the plots (test for trend) refer to the effect modification observed with each increase of one standardized log of the marker (see table S10). The histograms in the second row present the frequency distribution of observed marker values. Panel $\mathrm{C}$ gives the contour plots of the odds ratio for the odds ratio for the composite event of intubation or death for individuals receiving blood as a function of the antibody-dependent cellular cytotoxicity (ADCC) ratio and the neutralization titer. Over-layed data points indicate the value of the two antibody markers for each convalescent plasma transfusion in the study, with color code indicating blood supplier. The contours are obtained from a generalized additive logistic model for the primary outcome including blood supply center, treatment and the log transformed and standardized biomarkers using smoothing splines. Panel D similarly explores the joint effect of the ADCC ratio and levels of IgG against the SARS-CoV-2 full transmembrane Spike protein on the primary outcome. ADCC: Antibody-dependent cellular cytotoxicity; CCP: COVID-19 convalescent plasma; IgG: immunoglobulin G; OR: odds ratio; RBD: receptor-binding domain; S: SARS-CoV-2 Spike protein; SOC: standard of care. 
High-titre CCP

\section{Study}

Avendano Sola 2020

Bennett Guerrero 2020

Estcourt 2021

Gharbharan 2020

Horby 2021

Korper 2021

Li 2020

O'Donnell 2021

Ray 2020

Simonovich 2020

CONCOR-1 Blood supplier 1
Libster 2020

Sample Size Events Sample Size

$\begin{array}{rr}38 & 0 \\ 59 & 14 \\ 078 & 401 \\ 43 & 6 \\ 5795 & 1398 \\ 53 & 7 \\ 52 & 8 \\ 80 & 2 \\ 150 & 19 \\ 40 & 10 \\ 228 & 25 \\ 343 & 75\end{array}$

Total $(95 \% \mathrm{Cl})$

7959

Heterogeneity: $\mathrm{Tau}^{2}=0 ; \mathrm{Chi}^{2}=10.80, \mathrm{df}=11(\mathrm{P}=0.46) ; \mathrm{I}^{2}=0 \%$
Control

43

15

904

43

5763

52

51

80

73

40

105

173

7342

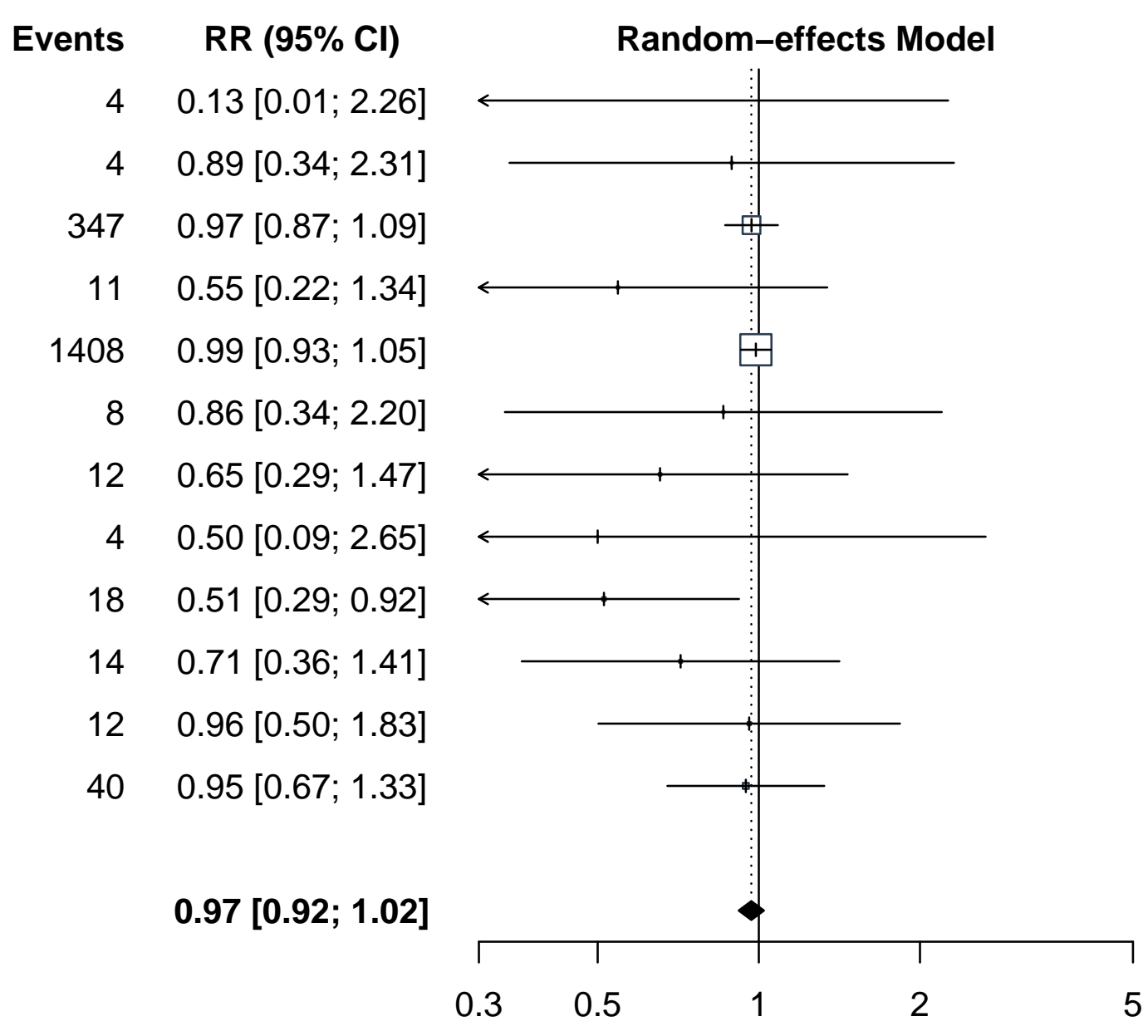

Favours High-titre CCP Favours Control 


\section{Unselected CCP Control}

\section{Study}

Agarwal 2020

AIQahtani 2020

Bajpai 2020

Hamdy Salman 2020

CONCOR-1 Blood supplier 2/3/4

Total $(95 \% \mathrm{CI})$

555

413

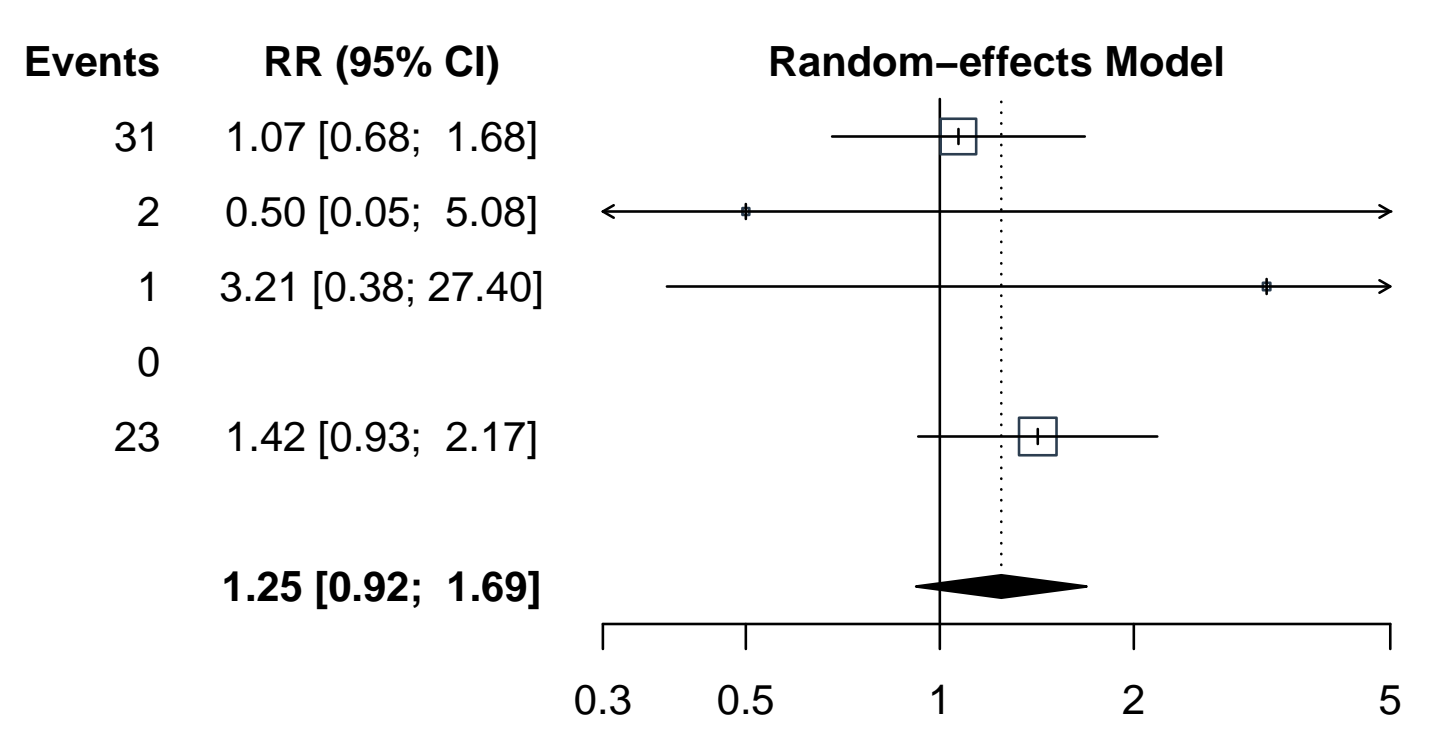

Favours unselected CCP Favours Control

$\operatorname{RR}(95 \% \mathrm{Cl})$ 
medRxiv preprint doi: https://doi.org/10.1101/2021.06.29.21259427; this version posted July 3, 2021. The copyright holder for this preprint (which was not certified by peer review) is the author/funder, who has granted medRxiv a license to display the preprint in perpetuity.

It is made available under a CC-BY-NC-ND 4.0 International license .

Figure 4 - Meta-analysis of mortality at 30 days in CONCOR-1 and other trials according to convalescent plasma selection strategy.

Panel A present the meta-analysis including trials that used high-titer plasma, whereas panel B presents those in which plasma which used a mix of low, medium and high-titre plasma. CCP: Covid-19 convalescent plasma; RR: relative risk. 


\section{Contents of CONCOR-1 Online-Only Appendix}

\section{List of CONCOR-1 Investigators ......................................................................................... 2}

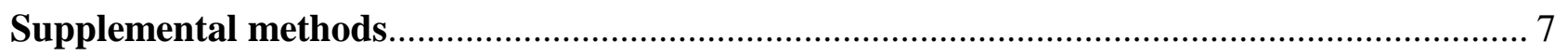

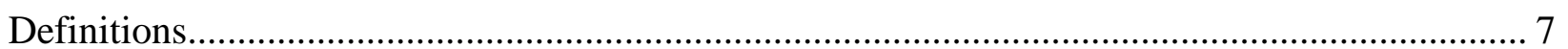

Inclusion/Exclusion Criteria .................................................................................................. 8

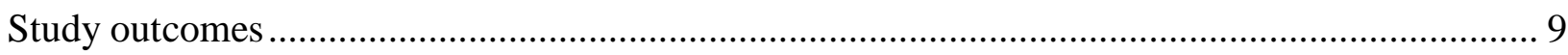

Electronic Case Report Form........................................................................................... 10

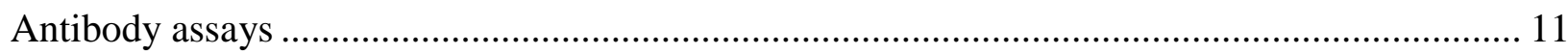

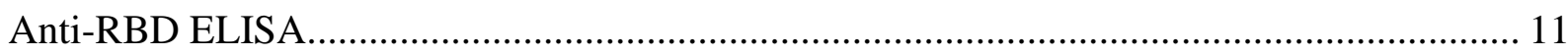

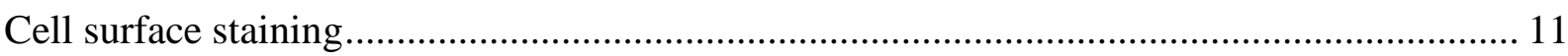

Antibody-dependent cellular cytotoxicity (ADCC) assay ........................................................ 11

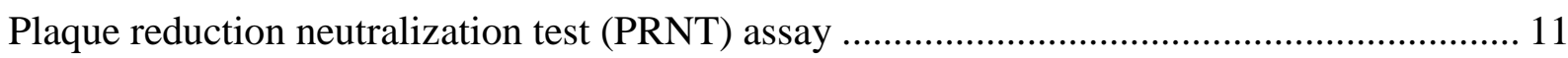

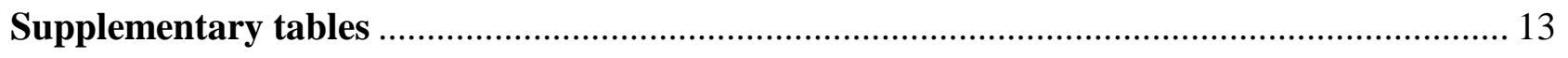

eTable 1: Reasons for exclusion from the intention to treat and per protocol populations. .......... 13

eTable 2: Baseline characteristics of the intention to treat population......................................... 14

eTable 3: Baseline characteristics of the per protocol population. ................................................. 17

eTable 4: Primary and secondary end points for the per protocol population................................ 20

eTable 5: Antibody test results overall and by participating blood supplier. ................................ 21

eTable 6: Adverse events at day 30 for the intention to treat population...................................... 22

eTable 7: Adverse events at day 30 for the per protocol population........................................... 24

eTable 8: Convalescent plasma adverse events at day 30 for the intention to treat population. .. 26

eTable 9: Convalescent plasma adverse events at day 30 for the per protocol population. .......... 28

eTable 10: Summary of logistic regression models with standardized continuous log marker

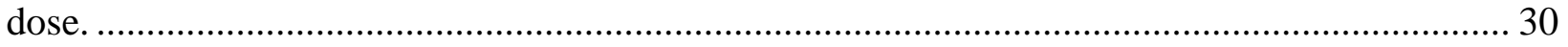

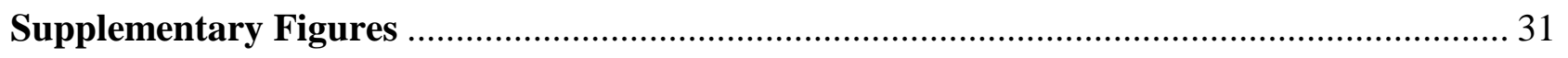

eFigure 1: Subgroup analysis for the per-protocol population. …………………………............. 31

eFigure 2: Cumulative incidence functions of intubation or in-hospital death by day 30 and inhospital death by day 90, and Kaplan-Meier estimate of distribution of length of stay in hospital

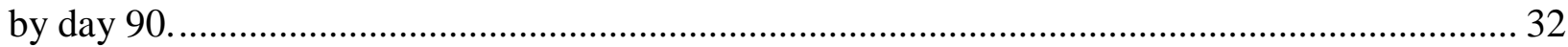

eFigure 3: Pairwise scatter plots of plasma antibody markers and empirical distribution functions.

eFigure 4: Exploration of the joint effect of antibody markers in convalescent plasma on the

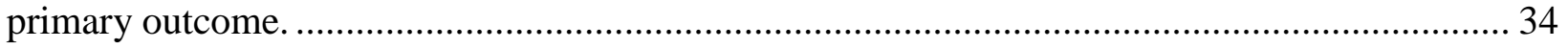

eFigure 5: Comparison of in-house ELISA to commercial assays. .............................................. 35

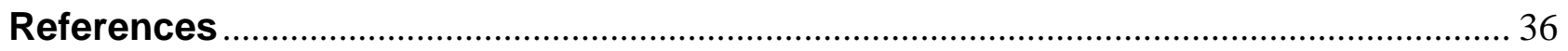




\section{List of CONCOR-1 Investigators}

Principal investigators: Donald Arnold MD, Philippe Bégin MD PhD, Jeannie Callum MD

Writing Committee: Donald Arnold MD, Philippe Bégin MD PhD, Jeannie Callum MD, Erin Jamula MSc, Nancy Heddle MSc, Richard Cook PhD, Andrés Finzi PhD, Luiz Amorim MD, Guillaume Beaudoin-Bussières PhD, Renée Bazin PhD, Richard Carl, Michaël Chassé MD PhD, PhD, Melissa M. Cushing MD, Nick Daneman MD, Dana V. Devine PhD, Jeannot Dumaresq MD, Dean A. Ferguson PhD, Marshall Glesby MD, PhD, Na Li PhD, Yang Liu MMath, Kent Cadogan Loftsgard, Alison McGeer MD, Nancy Robitaille MD, Bruce S. Sachais MD, PhD, Damon C. Scales MD PhD, Lisa Schwartz PhD, Nadine Shehata MD, Alan Tinmouth MD, Alexis F. Turgeon MD MSc, Heidi Wood PhD, Ryan Zarychanski MD MSc, Michelle Zeller MD

Steering Committee: Luiz Amorim MD, Renée Bazin PhD, Richard Carl, Michaël Chassé MD PhD, Richard Cook PhD, Melissa M. Cushing MD, Nick Daneman MD, Dana V. Devine PhD, Dean A. Ferguson PhD, Nancy Heddle MSc, Kent Cadogan Loftsgard, Alison McGeer MD, Nancy Robitaille MD, Bruce S. Sachais MD PhD, Damon C. Scales MD PhD, Lisa Schwartz PhD, Nadine Shehata MD, Alan Tinmouth MD, Alexis F. Turgeon MD MSc, Ryan Zarychanski MD MSc, Michelle Zeller MD

Central Methods Centre: Julie Carruthers, Erin Jamula, Kayla Lucier; McMaster Centre for Transfusion Research

Québec Study Coordination: Marie-Christine Auclair, Meda Avram, Michael Brassard, Sabrina Cerro, Véronica Martinez, Julie Morin, Marie Saint-Jacques, Maxime Veillette

Logistics Methods Centre: Chantal Armali, Amie Kron, Dimpy Modi; University of Toronto Quality in Utilization, Education and Safety in Transfusion (QUEST) Research Program, Sunnybrook Health Sciences Centre

Database Design and Management: Joanne Duncan, Pauline Justumus, Melanie St John, Geneviève St-Onge, Milena Hadzi-Tosev

Study Monitors: Jackie Amaral, Tanja Cerovina, Mila Khanna, Monika Wiseman, Karlee Trafford, Samantha Libfeld, Tamara Bright, Louise Rousseau, Rocco Paniccia, Sergio Assis , Daniele Aguiar; Ozmosis Research Inc.

Community Advisory Committee: Pierre-Marc Dion, Kent Cadogan Loftsgard*, Lawrence McGillivary, Andre Valleteau de Moulliac, Sheila A. Nyman, Stephanie Perilli, Paulette Jean Van Vliet, Nancy Heddle, Shannon Lane, Katerina Pavenski, Rebecca Pereira, Emily Sirotich (Advisors: Julie Abelson, Saara Greene, Lisa Schwartz) *referred to CONCOR-1 research partnership recruitment by the coordinators of the Strategy for Patient- Oriented Research - Primary and Integrated Health Care Innovations Network. - https://spor-pihci.com

Communications Committee: Michelle Zeller (Chair), Kayla Lucier, Aditi Khandelwal, Adrienne Silver, Dana Ellingham, Joanne Duncan, Caroline Gabe, Anne Trueman, Ana Catalina Alvarez Elias,Natasha Jawa, Julia Upton, Laurent Paul Ménard, Chantal Armali, Florence Meney, Rulan Parekh, Eric Dimitri, Menaka Pai, Julie Carruthers

Inventory and Distribution Committee: Alan Tinmouth (Chair), Michelle Zeller, Melanie St. John, Swarni Thakar, Sarah Longo

Antibody-dependent cellular cytotoxicity assay and flow cytometry: Centre Hospitalier de l’Université de Montréal Research Center: Guillaume Beaudoin-Bussières, Sai Priya Anand, Mehdi Benlarbi, Catherine Bourassa, Marianne Boutin, Jade Descôteaux-Dinelle, Gabrielle Gendron-Lepage, Guillaume Goyette, Annemarie Laumaea, Halima Medjahed, Jérémie Prévost, Jonathan Richard, Andrés Finzi.

Virus neutralization assay: Zoonotic Diseases and Special Pathogens, National Microbiology Laboratory, Public Health Agency of Canada, Winnipeg, Manitoba: Michael Drebot, Heidi Wood, Alyssia Robinson, Emelissa Mendoza, Kristina Dimitrova, Kathy Manguiat, Clark Phillipson, Michael Chan; Medical Microbiology \& Immunology, University of Alberta, Edmonton, Alberta: David Evans, James Lin.

Anti-RBD antibody : Héma-Québec : Lucie Boyer, Marc Cloutier, Mathieu Drouin, Éric Ducas, Nathalie Dussault, Marie-Josée Fournier, Patricia Landy, Marie-Ève Nolin, Josée Perreault, Tony Tremblay. 
medRxiv preprint doi: https://doi.org/10.1101/2021.06.29.21259427; this version posted July 3, 2021. The copyright holder for this preprint (which was not certified by peer review) is the author/funder, who has granted medRxiv a license to display the preprint in perpetuity. It is made available under a CC-BY-NC-ND 4.0 International license .

Health Economics Expertise: Feng Xie PhD

\title{
Participating Sites:
}

\section{British Columbia}

Abbotsford Regional Hospital, Abbotsford, British Columbia: Matthew Yan (Principal Investigator), David Liu, Michelle Wong, Gus Silverio, Kristin Walkus, Mikaela Barton, Katherine Haveman, Darlene Mueller, Ashley Scott

Royal Jubilee Hospital \& Victoria General Hospital, Victoria, British Columbia: Daniel Ovakim (Principal Investigator), Matthew Moher, Gordon Wood, Tracey Roarty, Fiona Auld, Gayle Carney, Virginia Thomson

St. Paul's Hospital, Vancouver, British Columbia: David Harris (Principal Investigator), Rodrigo Onell, Keith Walley, Katie Donohoe, Crystal Brunk, Geraldine Hernandez, Tina Jacobucci, Lynda Lazosky, Puneet Mann, Geeta Raval, Ligia Araujo Zampieri

Vancouver General Hospital, Vancouver, British Columbia: Andrew Shih (Principal Investigator), Mypinder Sekhon , Alissa Wright, Nicola James, Gaby Chang, Roy Chen, Kanwal Deol, Jorell Gantioqui, Elyse Larsen, Namita Ramdin, Margaret Roche, Kristin Rosinski, Lawrence Sham, Michelle Storms

\begin{abstract}
Alberta
Foothills Hospital, Peter Lougheed Centre, Rockyview General Hospital, Calgary, Alberta: Davinder Sidhu (Principal Investigator), Mark Gillrie, Etienne Mahe, Deepa Suryanarayan, Alejandra Ugarte-Torres, Traci Robinson, Mitchell Gibbs, Julia Hewsgirard, Marnie Holmes, Joanna McCarthy, Meagan Ody
\end{abstract}

University of Alberta, Royal Alexandra Hospital, Edmonton, Alberta: Susan Nahirniak (Principal Investigator), Karen Doucette, Wendy Sligl, Ashlesah Sonpar, Kimberley Robertson, Jeffrey Narayan, Leka Ravindran, Breanne Stewart, Lori Zapernick

\section{Saskatchewan}

Pasqua Hospital, Regina General Hospital, Regina, Saskatchewan: Donna Ledingham (Principal Investigator), Stephen Lee, Eric Sy, Alexander Wong, Karolina Gryzb, Sarah Craddock, Dennaye Fuchs, Danielle Myrah, Sana Sunny

Royal University Hospital, St. Paul's Hospital, Saskatoon, Saskatchewan: Oksana Prokopchuk-Gauk (Principal Investigator), Sheila Rutledge Harding, Siddarth Kogilwaimath, Nancy Hodgson, Dawn Johnson, Simona Meier, Kim Thomson

\section{Manitoba}

Grace General Hospital, Health Sciences Centre, St. Boniface General Hospital, Winnipeg, Manitoba: Arjuna Ponnampalam (Principal Investigator), Emily Rimmer (Principal Investigator), Amila Heendeniya (Principal Investigator), Brett Houston, Yoav Kenyan, Sylvain Lother, Kendiss Olafson, Barret Rush, Terry Wuerz, Ryan Zarychanski, Dayna Solvason, Lisa Albensi, Soumya Alias, Nora Choi, Laura Curtis, Maureen Hutmacher, Hessam Kashani, Debra Lane, Nicole Marten, Tracey Pronyk-Ward (Canadian Blood Services), Lisa Rigaux, Rhonda Silva, Quinn Tays

\section{Ontario}

Bluewater Health, Sarnia, Ontario: Glenna Cuccarolo (Principal Investigator), Renuka Naidu, Jane Mathews, Margaret Mai, Victoria Miceli, Liz Molson, Gayathri Radhakrishnan, Linda Schaefer, Michel Haddad, Shannon Landry

Grand River Hospital and St. Mary’s General Hospital, Kitchener, Ontario: Colin Yee (Principal Investigator), Robert Chernish, Rebecca Kruisselbrink, Theresa Liu, Jayna Jeromin, Atif Siddiqui, Carla Girolametto, Kristin Krokoszynski,

Hamilton General Hospital, Hamilton, Ontario: Menaka Pai (Principal Investigator), Daniela Leto, Cheryl Main, Alison Fox-Robichaud, Bram Rochwerg, Michelle Zeller, Erjona Kruja, Dana Ellingham, Erin Jamula, Meera Karunakaran, Shannon Lane, Kayla Lucier, Disha Sampat, Ngan Tang

Juravinski Hospital, Hamilton, Ontario: Michelle Zeller (Principal Investigator), Daniela Leto, Bram Rochwerg, Erjona 
medRxiv preprint doi: https://doi.org/10.1101/2021.06.29.21259427; this version posted July 3, 2021. The copyright holder for this preprint (which was not certified by peer review) is the author/funder, who has granted medRxiv a license to display the preprint in perpetuity. It is made available under a CC-BY-NC-ND 4.0 International license .

Kruja, Dana Ellingham, Erin Jamula, Meera Karunakaran, Shannon Lane, Kayla Lucier, Disha Sampat, Ngan Tang

Lakeridge Health, Oshawa and Ajax, Ontario: Karim Soliman (Principal Investigator), Daniel Ricciuto, Kelly Fusco, Taneera Ghate, Holly Robinson

London Health Sciences Centre, London, Ontario: Ziad Solh (Principal Investigator), Ian Ball, Sarah Shalhoub, Marat Slessarev, Michael Silverman, Eni Nano, Tracey Bentall, Eileen Campbell, Jeffery Kinney, Seema Parvathy, and the Medical Laboratory Technologists at London Health Sciences Centre

Markham Stouffville Hospital, Markham, Ontario: Valerie Sales (Principal Investigator), Evridiki Fera, Anthony La Delfa, Jeya Nadarajah, Henry Solow, Edeliza Mendoza, Katrina Engel, Diana Monaco, Laura Kononow, Sutharsan Suntharalingam

Mount Sinai Hospital, Toronto, Ontario: Nadine Shehata (Principal Investigator), Mike Fralick, Allison McGeer, Laveena Munshi, Samia Saeed, Omar Hajjaj, Elaine Hsu, and the Medical Laboratory Technologists at Mount Sinai Hospital

Niagara Health System, St. Catharines Site, St. Catharines, Ontario: Jennifer LY Tsang (Principal Investigator), Karim Ali, Erick Duan, George Farjou, Lorraine Jenson, Mary Salib, Lisa Patterson, Swati Anant, Josephine Ding, Jane Jomy

North York General Hospital, North York, Ontario: Eneko Arhanchiague (Principal Investigator), Pavani Das, Anna Geagea, Sarah Ingber, Elliot Owen, Alexandra Lostun, Tashea Albano, Antara Chatterjee, Manuel Giraldo, Jennifer Hickey, Ida Lee, Nea Okada, Nicholas Pasquale, Romina Ponzielli, Mary Rahmat, Shelina Sabur, Maria Schlag, Leonita Aguiar, Ashmina Damani, Suhyoung Hong, Mona Kokabi, Carolyn Perkins

The Ottawa Hospital, Ottawa, Onatrio: Alan Tinmouth (Principal Investigator), Juthaporn Cowan, Tony Giulivi, Derek MacFadden, Holly Carr (lead RC), Joe Cyr, Amanda Pecarskie, Rebecca Porteous, Priscila Ogawa Vedder, Irene Watpool.

Queensway Carleton Hospital, Ottawa, Ontario: Moira Rushton-Marovac (Principal Investigator), Phil Berardi, Laith Bustani, Alison Graver, Akshai Iyengar, Magdalena Kisilewicz, Jake Majewski, Misha Marovac, Ruchi Murthy, Karan Sharma, Marina Walcer

St. Joseph's Healthcare, Hamilton, Ontario: Shuoyan Ning (Principal Investigator), Zain Chagla, Jason Cheung, Erick Duan, France Clarke, Karlo Matic, Manuel Giraldo, Jennifer Hickey, Ida Lee, Nea Okada, Nicholas Pasquale, Romina Ponzielli, Mary Rahmat, Shelina Sabur, Maria Schlag

St. Joseph’s Health Centre, Toronto, Ontario: Katerina Pavenski (Principal Investigator), Travis Carpenter, Kevin Schwartz, Paril Suthar, Aziz Jiwajee, Daniel Lindsay, Aftab Malik, Brandon Tse

St. Michael’s Hospital, Toronto, Ontario: Katerina Pavenski (Principal Investigator), Larissa Matukas, Joel Ray, Paril Suthar, Shirley Bell, Aziz Jiwajee, Elizabeth Krok, Daniel Lindsay, Aftab Malik, Brandon Tse

Scarborough Health Network, Scarborough, Ontario: Rosemarie Lall (Principal Investigator), Ray Guo, Susan John, Vishal Joshi, Jessica Keen, Chris Lazongas, Jacqueline Ostro, Kevin Shore, Jianmin Wang, Jincheol Choi, Pujitha Nallapati, Tina Irwin, Victor Wang, Petra Sheldrake

Sunnybrook Health Sciences Centre, Toronto, Ontario: Yulia Lin (Principal Investigator), Neill Adhikari, Jeannie Callum, Nick Daneman, Hannah Wunsch, Amie Kron, Chantal Armali, Jacob Bailey, Harley Meirovich, Dimpy Modi, Connie Colavecchia

Trillium Health Partners, Mississauga, Ontario: Christopher Graham (Principal Investigator), Eiad Kahwash, Sachin Sud, Martin Romano

University Health Network, Toronto, Ontario: Christine Cserti-Gazdewich (Principal Investigator), Bryan Coburn, Lorenzo Del Sorbo, John Granton, Shahid Husain, Jacob Pendergrast, Abdu Sharkawy, Liz Wilcox, Samia Saeed, Chantal Armali, Omar Hajjaj, Maria Kulikova, Sophia Massin 
medRxiv preprint doi: https://doi.org/10.1101/2021.06.29.21259427; this version posted July 3, 2021. The copyright holder for this preprint (which was not certified by peer review) is the author/funder, who has granted medRxiv a license to display the preprint in perpetuity. It is made available under a CC-BY-NC-ND 4.0 International license .

Windsor Regional Hospital, Windsor, Ontario: Caroline Hamm (Principal Investigator), Wendy Kennette, Ian Mazzetti, Krista Naccarato, Grace Park, Alex Pennetti, Corrin Primeau, Cathy Vilag

\section{Québec}

Centre Hospitalier de l'Université de Montréal (CHUM), Montréal, Québec: Madeleine Durand (Principal Investigator), Michaël Chassé, Yves Lapointe, Anne-Sophie Lemay, Emmanuelle Duceppe, Benjamin Rioux-Massé, Cécile

Tremblay, Pascale Arlotto, Claudia Bouchard, Stephanie Matte, Marc Messier-Peet, COVID-19 Unit Personnel

CHU de Québec-Université Laval, Québec city, Québec: Alexis F. Turgeon (Principal Investigator), Charles-Langis Francoeur, François Lauzier, Vincent Laroche, Guillaume Leblanc, David Bellemare, Ève Cloutier, Olivier Costerousse, Émilie Couillard Chénard, Rana Daher, Marjorie Daigle, Stéphanie Grenier, Gabrielle Guilbeault, MariePier Rioux, Maude St-Onge, Antoine Tremblay

CHU de Sherbrooke, Sherbrooke, Québec: Alexandra Langlois (Principal Investigator), Brian Beaudoin, Luc Lanthier, Pierre Larrivée, Pierre-Aurèle Morin, Élaine Carbonneau, Robert Lacasse

CHU Sainte-Justine, Montréal, Québec: Olivier Drouin (Principal Investigator), Julie Autmizguine, Philippe Bégin, Isabelle Boucoiran, Geneviève Du Pont Thibodeau, Meda Avram, Mary-Ellen French, Annie La Haye, Vincent Lague, Karine Léveillé, Nancy Robitaille

CISSS Montérégie-Centre, Hôpital Charles-Lemoyne, Greenfield Park, Québec: Nadim Srour (Principal Investigator), Susan Fox, Diaraye Baldé, Lorraine Ménard, Suzanne Morissette, Miriam Schnorr-Meloche, Andrée-Anne Turcotte, Caroline Vallée

Hôpital Cité-de-la-Santé de Laval, Laval, Québec: Danielle Talbot (Principal Investigator), Stéphanie Castonguay, Tuyen Nguyen, Natalie Rivest, Marios Roussos, Esther Simoneau, Andreea Belecciu, Marie-Hélène Bouchard, Eric Daviau and his team, Cynthia Martin, Nicole Sabourin, Solange Tremblay

Hôpital de Chicoutimi, Chicoutimi, Québec: François Ménard (Principal Investigator), Émilie Gagné, Nancy-Lisa Gagné, Julie Larouche, Vanessa Larouche, Véronick Tremblay, Vicky Tremblay

Hôpital de Trois-Rivières, Trois-Rivières, Québec: André Poirier (Principal Investigator), Pierre Blanchette, David Claveau, Marianne Lamarre, Danielle Tapps

Hôpital du Sacré-Cœur-de-Montréal, Montréal, Québec: Christine Arseneault (Principal Investigator), Martin Albert, Anatolie Duca, Jean-Michel Leduc, Annie Barsalou, Suzanne Deschênes-Dion, Stéphanie Ibrahim, Stéphanie Ridyard, Julie Rousseau

Hôpital Maisonneuve-Rosemont, Montréal, Québec: Mélissa Boileau (Principal Investigator), Stéphane Ahern, MariePier Arsenault, Simon-Frédéric Dufresne, Luigina Mollica, Hang Ting Wang, Soizic Beau, Dominique Beaupré, Marjolaine Dégarie, Iris Delorme, Melissa Farkas, Michel-Olivier Gratton, Arnaud Guertin, Guylaine Jalbert, Mélanie Meilleur, Charles Ratté Labrecque, Élaine Santos, Julie Trinh Lu

Hôpital régional de St-Jérôme, St-Jérôme, Québec: Sébastien Poulin (Principal Investigator), Julien Auger, MarieClaude Lessard, Louay Mardini, Yves Pesant, Laurie Delves, Lisa Delves, Sophie Denault, Sofia Grigorova, Michelle Lambert, Nathalie Langille, Corinne Langlois, Caroline Rock, Yannick Sardin Laframboise

Hôtel-Dieu de Lévis, Lévis, Québec: Jeannot Dumaresq (Principal Investigator), Danièle Marceau, Patrick Archambault, Joannie Bélanger Pelletier, Estel Duquet-Deblois, Vanessa Dupuis-Picard, Yannick Hamelin, Samuel Leduc, Mélanie Richard

Institut de Cardiologie et Pneumologie de Québec - Université Laval, Québec city, Québec: Andréanne Côté (Principal Investigator), Marc Fortin, Philippe Gervais, Vincent Laroche, Marie-Ève Boulay, Claudine Ferland, Jakie Guertin, Johane Lepage, Annie Roy, BB and COVID-19 unit personnel

Jewish General Hospital, Montréal, Québec: Christina Greenaway (Principal Investigator), Sarit Assouline, Stephen Caplan, Ling Kong, Christina Canticas, Carley Mayhew, Johanne Ouedraogo, Tévy-Suzy Tep 
medRxiv preprint doi: https://doi.org/10.1101/2021.06.29.21259427; this version posted July 3, 2021. The copyright holder for this preprint (which was not certified by peer review) is the author/funder, who has granted medRxiv a license to display the preprint in perpetuity. It is made available under a CC-BY-NC-ND 4.0 International license .

McGill University Hospital Center, Montréal, Québec: Makeda Semret (Principal Investigator), Matthew Cheng, Marina Klein, Nadine Kronfli, Patricia Pelletier, Salman Qureshi, Donald Vinh, Robert Dziarmaga, Hansi Peiris, Karène Proulx-Boucher, Jonathan Roger, Molly-Ann Rothschild, Chung-Yan Yuen

Hôtel-Dieu de Lévis, Lévis, Québec: Jeannot Dumaresq (Principal Investigator), Patrick Archambault, Danièle Marceau, Joannie Bélanger Pelletier, Estel Duquet-Deblois, Vanessa Dupuis-Picard, Yannick Hamelin, Samuel Leduc, Mélanie Richard

\section{New Brunswick}

Vitalité Health Network, Moncton, New Brunswick: Gabriel Girouard (Principal Investigator), Richard Garceau, Rémi LeBlanc, Eve St-Hilaire, Patrick Thibeault, Karine Morin, Gilberte Caissie, Jackie Caissie Collette, Line Daigle, Mélissa Daigle, Bianca Gendron, Nathalie Godin, Angela Lapointe, Gabrielle Moreau, Lola Ouellette-Bernier, Joanne Rockburn, Brigitte Sonier-Ferguson, Christine Wilson, and the many collaborating nursing staff on the ICU and COVID units.

\section{New York}

Weill Cornell Medicine, New York City, New York: Marshall Glesby (Principal Investigator), Melissa M. Cushing, Robert DeSimone, Grant Ellsworth, Rebecca Fry, Noah Goss, Roy Gulick, Carlos Vaamonde, Timothy Wilkin, Celine Arar, Jonathan Berardi, Dennis Chen, Cristina Garcia-Miller, Arthur Goldbach, Lauren Gripp, Danielle Hayden, Kathleen Kane, Jiamin Li, Kinge-Ann Marcelin, Christina Megill, Meredith Nelson, Ailema Paguntalan, Gabriel Raab, Gianna Resso, Roxanne Rosario, Noah Rossen, Shoran Tamura, Ethan Zhao

New York-Presbyterian Brooklyn Methodist Hospital, New York City, New York: Andy Huang (Principal Investigator), Cheryl Goss, Young Kim, Eshan Patel, Sonal Paul, Tiffany Romero, Naima ElBadri, Lina Flores, Tricia Sandoval

New York-Presbyterian Lower Manhattan Hospital, New York City, New York: Harjot Singh (Principal Investigator), Shashi Kapadia, Ljiljana Vasovic, Shanna-Kay Griffiths, Daniel Alvarado, Fiona Goudy, Melissa Lewis, Marina Loizou, Rita Louie

\section{Brazil}

Hemorio, Hospital and Regional Blood Center, Rio de Janeiro: Luiz Amorim Filho (Principal Investigator), Rodrigo Guimaraes, Maria Esther Lopes, Margarida Pêcego, Caroline Gabe, Natalia Rosario, Carlos Alexandre da Costa Silva, Thais Oliveira, Maria Cristina Lopes, Sheila Mateos

\section{Blood Suppliers}

Canadian Blood Services: Dana Devine, Chantale Pambrun, Sylvia Torrance, Steven Drews, Janet McManus, Oriela Cuevas, Wanda Lafresne, Patrizia Ruoso, Christine Shin, Tony Steed, Rachel Ward, and the many CBS staff who assisted with the collection and provision of COVID-19 convalescent plasma.

Héma-Québec: Isabelle Allard, Renée Bazin, Marc Germain, Sébastien Girard, Éric Parent, Claudia-Mireille Pigeon, Nancy Robitaille.

Hemorio, Hospital and Regional Blood Center, Rio de Janeiro: Luiz Amorim Filho (Principal Investigator), Rodrigo Guimaraes, Maria Esther Lopes, Margarida Pêcego, Caroline Gabe, Natalia Rosario, Carlos Alexandre da Costa Silva, Thais Oliveira, Maria Cristina Lopes, Sheila Mateos

New York Blood Center: Lucette Hall, Sarai Paradiso, Bruce Sachais, Donna Strauss

The authors would like to acknowledge recovered patients that donated their plasma, the staff involved in the recruitment, collection, qualification, and distribution of COVID-19 convalescent plasma and the staff of the COVID19 wards who made the study possible.

The authors would also like to thank the members of the Independent Data Safety Monitoring Committee: Keyvan Karkouti MD, Robert Fowler MD, Meghan Delaney MD, George Tomlinson PhD, Darryl Davis MD, and Boris Juelg MD. 
medRxiv preprint doi: https://doi.org/10.1101/2021.06.29.21259427; this version posted July 3, 2021. The copyright holder for this preprint (which was not certified by peer review) is the author/funder, who has granted medRxiv a license to display the preprint in perpetuity. It is made available under a CC-BY-NC-ND 4.0 International license .

\section{Supplemental methods}

\section{Definitions}

\section{Adverse event (AE)}

An AE is any untoward medical occurrence that occurs in a patient or clinical investigation subject administered a pharmaceutical product, and which does not necessarily have a causal relationship with the treatment assignment. An AE can therefore be any unfavorable and unintended sign (including abnormal laboratory finding), symptom, or disease temporally associated with the use of an investigational product, whether or not considered related to the product.

\section{Adverse drug reaction (ADR)}

An ADR is any noxious and unintended response to an IMP related to any dose. The phrase 'response to an IMP' means that a causal relationship between the IMP and an AE carries at least a reasonable possibility, i.e., the relationship cannot be ruled out.

\section{Other significant AEs}

Any marked laboratory abnormalities or any AEs that lead to an intervention, including withdrawal of drug treatment, dose reduction, or significant additional concomitant therapy.

\section{Severity of AEs}

The severity of each AE must be assessed by the Investigator and graded based on CTCAE v4.03. A clinical AE NOT identified elsewhere in the grading table will be graded using one of the following categories:

1. Mild: Mild symptoms causing no or minimal interference with usual social \& functional activities with intervention not indicated

2. Moderate: Moderate symptoms causing greater than minimal interference with usual social \& functional activities with intervention indicated

3. Severe: Severe symptoms causing inability to perform usual social and functional activities with intervention or hospitalization indicated

4. Life-threatening: Potentially life-threatening symptoms causing inability to perform basic self-care functions with intervention indicated to prevent permanent impairment, persistent disability, or death.

5. Death: The AE resulted in the subject's death.

Serious AE (SAE)

A SAE is generally defined as any untoward medical occurrence that at any dose:

1. Results in death;

2. Is life-threatening; this means that the subject is at risk of death at the time of the event; it does not mean that the event hypothetically might have caused death if it was more severe;

3. Requires hospitalization (overnight or longer) or prolongation of existing hospitalization or invasive procedure;

4. Results in persistent or significant disability or incapacity;

5. Results in congenital anomaly or birth defect;

6. Is not be immediately life-threatening or result in death or hospitalization but may jeopardize the subject or require intervention to prevent one of the above outcomes. 
medRxiv preprint doi: https://doi.org/10.1101/2021.06.29.21259427; this version posted July 3, 2021. The copyright holder for this preprint (which was not certified by peer review) is the author/funder, who has granted medRxiv a license to display the preprint in perpetuity.

It is made available under a CC-BY-NC-ND 4.0 International license .

Inclusion/Exclusion Criteria

Inclusion criteria

1. $\geq 16$ years of age ( $\geq 18$ years of age in the United States, Brazil, and Israel)

2. Admitted to hospital for confirmed COVID-19 respiratory illness

3. Receiving supplemental oxygen

4. $500 \mathrm{~mL}$ of ABO compatible CCP is available

\section{Exclusion criteria}

1. Onset of signs or symptoms of COVID-19 respiratory illness $>12$ days prior to randomization (eg. cough, chest pain, dyspnea, or hypoxia)

2. Intubated or plan in place for intubation

3. Plasma is contraindicated (e.g. history of anaphylaxis from transfusion)

4. Decision in place for no active treatment 
medRxiv preprint doi: https://doi.org/10.1101/2021.06.29.21259427; this version posted July 3, 2021. The copyright holder for this preprint (which was not certified by peer review) is the author/funder, who has granted medRxiv a license to display the preprint in perpetuity.

It is made available under a CC-BY-NC-ND 4.0 International license .

Study outcomes

\section{Primary outcomes}

The primary outcome is a composite of intubation or death at Day 30.

\section{Secondary outcomes}

- $\quad$ Time to intubation or death

- Ventilator-free days at day 30

- $\quad$ In-hospital death by Day 90

- $\quad$ Time to in-hospital death

- $\quad$ Death by Day 30

- $\quad$ Length of stay in ICU

- $\quad$ Length of stay in hospital

- $\quad$ Need for ECMO

- $\quad$ Need for renal replacement therapy

- $\quad$ Myocarditis

- $\quad$ Patient-reported outcome at Day 30

- $\quad$ Incremental cost per quality-adjusted life year (QALY)

- $\quad$ CPP transfusion-associated AEs

- $\quad$ Grade 3 and 4 SAEs

- $\quad$ Cumulative incidence of Grade 3 and 4 SAEs (CTCAE) 
medRxiv preprint doi: https://doi.org/10.1101/2021.06.29.21259427; this version posted July 3, 2021. The copyright holder for this preprint (which was not certified by peer review) is the author/funder, who has granted medRxiv a license to display the preprint in perpetuity.

It is made available under a CC-BY-NC-ND 4.0 International license .

\section{Electronic Case Report Form}

Study data were collected and managed using REDCap electronic data capture tools hosted at McMaster University. REDCap (Research Electronic Data Capture) is a secure, web-based application designed to support data capture for research studies, providing: 1) an intuitive interface for validated data entry; 2) audit trails for tracking data manipulation and export procedures; 3 ) automated export procedures for seamless data downloads to common statistical packages; and 4) procedures for importing data from external sources. ${ }^{1}$ 
medRxiv preprint doi: https://doi.org/10.1101/2021.06.29.21259427; this version posted July 3, 2021. The copyright holder for this preprint

(which was not certified by peer review) is the author/funder, who has granted medRxiv a license to display the preprint in perpetuity.

It is made available under a CC-BY-NC-ND 4.0 International license .

Antibody assays

\section{Anti-RBD ELISA}

Recombinant SARS-CoV-2 S RBD proteins $(2.5 \mu \mathrm{g} / \mathrm{ml})$, were prepared in PBS and were adsorbed to plates (100 $\mu \mathrm{l} /$ well; Immulon 2HB, Thermo Scientific ) overnight at $4^{\circ} \mathrm{C}$. Coated wells were subsequently blocked with blocking buffer (Phosphate-buffered saline [PBS] containing 0.1\% Tween20 and 2\% BSA) for $1 \mathrm{~h}$ at room temperature. Wells were then washed four times with washing buffer (PBS containing 0.1\% Tween20). CR3022 mAb (50ng/ml final concentration) or plasma from SARS-CoV-2-infected or uninfected donors (1/100 dilution )in blocking buffer) were incubated with the RBD-coated wells for $1 \mathrm{~h}$ at room temperature. Plates were washed four times with washing buffer followed by incubation with HRP conjugated goat anti-human IgA+IgG+IgM diluted in blocking buffer (Jackson ImmunoResearch Laboratories, Inc.) for $1 \mathrm{~h}$ at room temperature, followed by four washes. HRP enzyme activity was determined after a 20 minute incubation with 3,3',5,5'-Tetramethylbenzidine (TMB, ESBE Scientific) followed by blocking with H2SO4 1N. Plates were read using a microplate reader (Synergy H1, Bio-Tek) within 30 min after blocking the reaction. The cutoff value for seropositivity, set at 0.250 , was calculated using the mean OD + 3 standard deviations of 13 COVID-19 negative plasma samples (collected in 2019, before the outbreak of SARS-CoV-2) plus a 15\% inter-assay coefficient of variation. Following implementation of the assay, we used results from the analysis of 94 convalescent plasma samples and 88 negative samples and the determined cut-off value yielded a sensitivity of $98.9 \%$ and a specificity of $98.5 \%$.

\section{Cell surface staining}

293T and 293T.SARS-CoV-2.Spike cells ${ }^{2}$ were mixed at a 1:1 ratio and stained with the anti-RBD monoclonal antibody CR3022 $(5 \mu \mathrm{g} / \mathrm{mL})$ or plasma (1/250 dilution) for 45 minutes at $37^{\circ} \mathrm{C}$. Cells were then washed 2 times with PBS before being incubated with secondary antibodies. AlexaFluor-647 conjugated goat anti-human IgA, IgM, IgM+IgG+IgA (1,70 $\mu \mathrm{g} / \mathrm{mL}$; Jackson ImmunoResearch) or AlexaFluor-647 conjugated mouse anti-human IgG (3 $\mu \mathrm{g} / \mathrm{mL}$; Biolegend) were used as secondary antibodies to stain cells for 20 minutes at room temperature. Cells were then washed 2 times with PBS before being fixed in $2 \%$ PBS-formaldehyde solution. The percentage of transduced cells (GFP+ cells) was determined by gating on the living cell population based on viability dye staining (AquaVivid, Thermo Fisher Scientific). Samples were acquired on a LSRII cytometer (BD Biosciences) and data analysis was performed using FlowJo v10.7.1 (Tree Star).

\section{Antibody-dependent cellular cytotoxicity (ADCC) assay}

ADCC was measured as described previously. ${ }^{3}$ Briefly, parental CEM.NKr CCR5+ cells were mixed at a 1:1 ratio with CEM.NKr.SARS-CoV-2.Spike cells. These cells were stained for viability (AquaVivid; Thermo Fisher Scientific) and cellular dye (cell proliferation dye eFluor670; Thermo Fisher Scientific) to be used as target cells. Overnight rested PBMCs from healthy donors were stained with another cellular marker (cell proliferation dye eFluor450; Thermo Fisher Scientific) and used as effector cells. Stained target and effector cells were mixed at a ratio of 1:10 in 96-well V-bottom plates. Plasma (1/500 dilution) or monoclonal antibodies CR3022 and CV3-13 $(1 \mu \mathrm{g} / \mathrm{mL})$ were added to the appropriate wells. ${ }^{4}$ The plates were subsequently centrifuged for $1 \mathrm{~min}$ at $300 \mathrm{xg}$, and incubated at $37^{\circ} \mathrm{C}, 5 \% \mathrm{CO} 2$ for 5 hours before being fixed in a 2\% PBS-formaldehyde solution. ADCC activity (ADCC\%) was calculated using the formula: [(\% of GFP+ cells in Targets plus Effectors)-(\% of GFP+ cells in Targets plus Effectors plus plasma/antibody)]/(\% of GFP+ cells in Targets) $\mathrm{x} 100$ by gating on transduced live target cells. Plasma from previous experiments and two monoclonal antibodies (CR3022, CV3-13) were used as quality controls and to standardize the ADCC ratio between experiments. All samples were acquired on an LSRII cytometer (BD Biosciences) and data analysis was performed using FlowJo v10.7.1 (Tree Star).

\section{Plaque reduction neutralization test (PRNT) assay}

The PRNT assay at NML was performed as previously published. ${ }^{5}$ SARS-CoV-2 (Canada/ON_ON-VIDO-01-2/2020, EPI_ISL_42517) stocks were titrated for use in the PRNT. Serological specimens were diluted 2-fold from 1:20 to 1:640 in DMEM supplemented with 2\% FBS and incubated with $50 \mathrm{PFU}$ of SARS-CoV-2 at $37^{\circ} \mathrm{C}$ and $5 \% \mathrm{CO} 2$ for 1 hour. The sera-virus mixtures were added to 12 -well plates containing Vero E6 cells at $100 \%$ confluence, followed by incubation at $37^{\circ} \mathrm{C}$ and $5 \% \mathrm{CO} 2$ for 1 hour. After adsorption, a liquid overlay composed of $1.5 \%$ carboxymethylcellulose 
medRxiv preprint doi: https://doi.org/10.1101/2021.06.29.21259427; this version posted July 3, 2021. The copyright holder for this preprint (which was not certified by peer review) is the author/funder, who has granted medRxiv a license to display the preprint in perpetuity. It is made available under a CC-BY-NC-ND 4.0 International license .

diluted in MEM, supplemented with 4\% FBS, L-glutamine, nonessential amino acids, and sodium bicarbonate, was added to each well; the plates were incubated at $37^{\circ} \mathrm{C}$ and $5 \% \mathrm{CO} 2$ for 72 hours. The liquid overlay was removed, and the cells were fixed with $10 \%$ neutral-buffered formalin for 1 hour at room temperature. The monolayers were stained with $0.5 \%$ crystal violet for 10 minutes and washed with $20 \%$ ethanol. Plaques were enumerated and compared with controls. The highest serum dilution resulting in $50 \%$ and $90 \%$ reduction in plaques compared with controls were defined as the PRNT50 and PRNT90 endpoint titers, respectively. 
medRxiv preprint doi: https://doi.org/10.1101/2021.06.29.21259427; this version posted July 3, 2021. The copyright holder for this preprint (which was not certified by peer review) is the author/funder, who has granted medRxiv a license to display the preprint in perpetuity.

Supplementary tables

eTable 1: Reasons for exclusion from the intention to treat and per protocol populations.

\begin{tabular}{|c|c|c|}
\hline & $\begin{array}{l}\text { Convalescent } \\
\text { Plasma } \\
(\mathrm{n}, \%)\end{array}$ & $\begin{array}{l}\text { Standard } \\
\text { of Care } \\
(n, \%)\end{array}$ \\
\hline All randomized patients & 627 & 313 \\
\hline Consent withdrawal & $2(0.3)$ & $0(0.0)$ \\
\hline $\begin{array}{l}\text { Lost to follow-up (data on primary outcome unavailable; } \\
\text { these patients were discharged alive before day } 30 \text {, and } \\
\text { could not be contacted on day } 30 \text { ) }\end{array}$ & $11(1.8)$ & $6(1.9)$ \\
\hline Intention to treat population & 614 & 307 \\
\hline \multicolumn{3}{|l|}{ Ineligible for the trial } \\
\hline $\begin{array}{l}\text { Not receiving supplemental oxygen at the time of } \\
\text { randomization (on oxygen at screening) }\end{array}$ & $4(0.6)$ & $4(1.3)$ \\
\hline $\begin{array}{l}\text { Any symptoms onset }>12 \text { days prior to } \\
\text { randomization }^{\mathrm{a}}\end{array}$ & $1(0.2)$ & $0(0.0)$ \\
\hline \multicolumn{3}{|l|}{ Protocol deviation } \\
\hline \multicolumn{3}{|l|}{ CCP arm received no CCP } \\
\hline Received regular plasma & $1(0.2)$ & \\
\hline Investigator decision & $9(1.4)$ & \\
\hline Patient refused & $7(1.1)$ & \\
\hline Total volume transfused $<400 \mathrm{ml}$ & $11(1.8)$ & \\
\hline $\begin{array}{l}\text { CCP transfusion ended }>24 \text { hour post } \\
\text { randomization }\end{array}$ & $33(5.3)$ & \\
\hline Per protocol population & $548(87.4)$ & $303(96.8)$ \\
\hline
\end{tabular}

${ }^{a}$ For protocol version 5.0 or earlier (post-randomization, patient revised date of onset of symptoms) 
medRxiv preprint doi: https://doi.org/10.1101/2021.06.29.21259427; this version posted July 3, 2021. The copyright holder for this preprint (which was not certified by peer review) is the author/funder, who has granted medRxiv a license to display the preprint in perpetuity.

It is made available under a CC-BY-NC-ND 4.0 International license .

\section{eTable 2: Baseline characteristics of the intention to treat population.}

Excluding the 19 patients lost to follow-up at day 30 or withdrawing consent before day 30 . Categorical data presented as number (percentage) and continuous variables as mean \pm standard deviation and median (interquartile range).

\begin{tabular}{|c|c|c|c|}
\hline Characteristic & $\begin{array}{l}\text { Convalescent Plasma } \\
\qquad n=614\end{array}$ & $\begin{array}{c}\text { Standard of Care } \\
\qquad n=307\end{array}$ & $\begin{array}{l}\text { Overall } \\
n=921\end{array}$ \\
\hline Age - yr & $67.8 \pm 16.0 ; 69(58,80)$ & $\begin{array}{l}67.3 \pm 14.8 ; 68 \\
\quad(58,78)\end{array}$ & $\begin{array}{c}67.6 \pm 15.6 ; 69 \\
(58,79)\end{array}$ \\
\hline$\geq 60$ years & $433(70.5)$ & $216(70.4)$ & $649(70.5)$ \\
\hline \multicolumn{4}{|l|}{ Sex } \\
\hline Male & $362(59.0)$ & $183(59.6)$ & $545(59.2)$ \\
\hline Pregnant at randomization & $4(0.7)$ & & $4(0.4)$ \\
\hline \multicolumn{4}{|l|}{ Ethnicity } \\
\hline White & 101(16.4) & $44(14.3)$ & 145(15.7) \\
\hline Asian & $300(48.9)$ & $151(49.2)$ & $451(49.0)$ \\
\hline Hispanic or Latino & $25(4.1)$ & $11(3.6)$ & $36(3.9)$ \\
\hline Black & $33(5.4)$ & $9(2.9)$ & $42(4.6)$ \\
\hline Other & $37(6.0)$ & $28(9.1)$ & $65(7.1)$ \\
\hline Unknown & 118(19.2) & $64(20.8)$ & 182(19.8) \\
\hline \multicolumn{4}{|l|}{ ABO blood group } \\
\hline $\mathrm{O}$ & $265(43.2)$ & $112(36.5)$ & $377(40.9)$ \\
\hline$A$ & 231(37.6) & $119(38.8)$ & $350(38.0)$ \\
\hline B & $87(14.2)$ & $54(17.6)$ & 141(15.3) \\
\hline$A B$ & $31(5.0)$ & $22(7.2)$ & $53(5.8)$ \\
\hline $\mathrm{BMI}-\mathrm{kg} / \mathrm{m}^{2}$ & $30.1 \pm 7.5 ; 29(25,33)$ & $30.0 \pm 7.5 ; 29(25,33)$ & $\begin{array}{c}30.1 \pm 7.5 ; 29 \\
(25,33)\end{array}$ \\
\hline $\mathrm{BMI}<30$ & $248(40.4)$ & 121(39.4) & $369(40.1)$ \\
\hline $\mathrm{BMI} \geq 30$ & 198(32.2) & $100(32.6)$ & 298(32.4) \\
\hline Unknown & $168(27.4)$ & $86(28.0)$ & $254(27.6)$ \\
\hline \multicolumn{4}{|l|}{ Smoking status } \\
\hline Never Smoking & $324(52.8)$ & $159(51.8)$ & $483(52.4)$ \\
\hline Former Smoker & $188(30.6)$ & 104(33.9) & $292(31.7)$ \\
\hline Current Smoker & $19(3.1)$ & $6(2.0)$ & $25(2.7)$ \\
\hline Unknown & $83(13.5)$ & $38(12.4)$ & 121(13.1) \\
\hline
\end{tabular}




\begin{tabular}{|c|c|c|c|}
\hline Characteristic & $\begin{array}{l}\text { Convalescent Plasma } \\
n=614\end{array}$ & $\begin{array}{c}\text { Standard of Care } \\
n=307\end{array}$ & $\begin{array}{l}\text { Overall } \\
\mathrm{n}=921\end{array}$ \\
\hline \multicolumn{4}{|l|}{ Smoking history } \\
\hline$<15$ years or non-smoker & $355(57.8)$ & $172(56.0)$ & $527(57.2)$ \\
\hline$\geq 15$ years & $84(13.7)$ & $53(17.3)$ & $137(14.9)$ \\
\hline Smokers with unknown history & $92(15.0)$ & $44(14.3)$ & $136(14.8)$ \\
\hline Unknown & 83(13.5) & $38(12.4)$ & $121(13.1)$ \\
\hline \multicolumn{4}{|l|}{ Presence of comorbidity } \\
\hline Diabetes & $214(34.9)$ & 104(33.9) & $318(34.5)$ \\
\hline Cardiac disease & $379(61.7)$ & 193(62.9) & $572(62.1)$ \\
\hline Baseline respiratory diseases & $145(23.6)$ & $79(25.7)$ & $224(24.3)$ \\
\hline $\begin{array}{l}\text { Abnormal CT chest or chest } \mathrm{x} \text { - } \\
\text { ray result before randomization }\end{array}$ & $553(90.1)$ & $261(85.0)$ & $814(88.4)$ \\
\hline \multicolumn{4}{|l|}{$\begin{array}{l}\text { Medication for other research } \\
\text { study at baseline }\end{array}$} \\
\hline No & $562(91.5)$ & 267(87.0) & $829(90.0)$ \\
\hline Yes & $52(8.5)$ & $40(13.0)$ & $92(10.0)$ \\
\hline \multicolumn{4}{|l|}{$\begin{array}{l}\text { Medication for COVID-19 at } \\
\text { baseline }\end{array}$} \\
\hline Azithromycin & $277(45.1)$ & $134(43.6)$ & $411(44.6)$ \\
\hline Other antibiotics & $400(65.1)$ & 182(59.3) & $582(63.2)$ \\
\hline Steroid/Immunomodulator & $489(79.6)$ & $244(79.5)$ & $733(79.6)$ \\
\hline Antiviral medications & $161(26.2)$ & $78(25.4)$ & $239(26.0)$ \\
\hline Anticoagulants & $345(56.2)$ & $175(57.0)$ & $520(56.5)$ \\
\hline Other COVID-19 Medications & $76(12.4)$ & $36(11.7)$ & $112(12.2)$ \\
\hline \multicolumn{4}{|l|}{$\begin{array}{l}\text { Medication not for COVID-19 at } \\
\text { baseline }\end{array}$} \\
\hline ACE inhibitor & 84(13.7) & $62(20.2)$ & 146(15.9) \\
\hline ACE receptor blocker(ARB) & $76(12.4)$ & $46(15.0)$ & $122(13.2)$ \\
\hline $\begin{array}{l}\text { Non-steroidal anti-inflammatory } \\
\text { drugs(NSAIDs) }\end{array}$ & $77(12.5)$ & $51(16.6)$ & 128(13.9) \\
\hline Colchicine & $5(0.8)$ & $2(0.7)$ & $7(0.8)$ \\
\hline Systemic corticosteroids & $60(9.8)$ & $35(11.4)$ & $95(10.3)$ \\
\hline Inhaled corticosteroids & $82(13.4)$ & $42(13.7)$ & $124(13.5)$ \\
\hline Immunomodulatory agents & $22(3.6)$ & $17(5.5)$ & $39(4.2)$ \\
\hline
\end{tabular}


medRxiv preprint doi: https://doi.org/10.1101/2021.06.29.21259427; this version posted July 3, 2021. The copyright holder for this preprint (which was not certified by peer review) is the author/funder, who has granted medRxiv a license to display the preprint in perpetuity.

It is made available under a CC-BY-NC-ND 4.0 International license .

\begin{tabular}{|l|c|c|c|}
\hline Characteristic & $\begin{array}{c}\text { Convalescent Plasma } \\
\mathbf{n = 6 1 4}\end{array}$ & $\begin{array}{c}\text { Standard of Care } \\
\mathbf{n = 3 0 7}\end{array}$ & $\begin{array}{c}\text { Overall } \\
\mathbf{n = 9 2 1}\end{array}$ \\
\hline \multicolumn{1}{|c|}{ Anticoagulants } & $132(21.5)$ & $63(20.5)$ & $195(21.2)$ \\
Oxygen status at baseline (FiO2) & $49.7 \pm 25.3 ; 40(30,65)$ & $\begin{array}{c}49.1 \pm 25.3 ; 40 \\
(30,60)\end{array}$ & $\begin{array}{c}49.5 \pm 25.3 ; 40 \\
(30,64)\end{array}$ \\
$\begin{array}{l}\text { Time from first Covid-19 } \\
\text { symptom to randomization } \\
\text { (days) }\end{array}$ & $8.0 \pm 3.8 ; 8(5,10)$ & $7.8 \pm 3.4 ; 8(5,10)$ & $7.9 \pm 3.7 ; 8(5,10)$ \\
$\begin{array}{l}\text { Time from Covid-19 diagnosis } \\
\text { to randomization (days) }\end{array}$ & $5.0 \pm 3.6 ; 4(2,8)$ & $5.0 \pm 4.4 ; 4(2,7)$ & $5.0 \pm 3.9 ; 4(2,7)$ \\
Enrolled in other clinical trials & $166(27.0)$ & $96(31.3)$ & $262(28.4)$ \\
\hline
\end{tabular}

aDay of positive Covid-19 test. 
medRxiv preprint doi: https://doi.org/10.1101/2021.06.29.21259427; this version posted July 3, 2021. The copyright holder for this preprint (which was not certified by peer review) is the author/funder, who has granted medRxiv a license to display the preprint in perpetuity.

It is made available under a CC-BY-NC-ND 4.0 International license .

eTable 3: Baseline characteristics of the per protocol population.

Categorical data presented as number (percentage) and continuous variables as mean \pm standard deviation and median (interquartile range).

\begin{tabular}{|c|c|c|c|}
\hline Characteristic & $\begin{array}{l}\text { Convalescent Plasma } \\
\qquad n=548\end{array}$ & $\begin{array}{l}\text { Standard of Care } \\
\qquad n=303\end{array}$ & $\begin{array}{l}\text { Overall } \\
n=851\end{array}$ \\
\hline Age - yr & $67.1 \pm 16.1 ; 68(57,79)$ & $\begin{array}{l}67.3 \pm 14.9 ; 68 \\
\quad(58,78)\end{array}$ & $\begin{array}{c}67.2 \pm 15.7 ; 68 \\
(57,79)\end{array}$ \\
\hline$<60$ years & 169(30.8) & $90(29.7)$ & $259(30.4)$ \\
\hline$\geq 60$ years & $379(69.2)$ & $213(70.3)$ & $592(69.6)$ \\
\hline \multicolumn{4}{|l|}{ Sex } \\
\hline Male & 323(58.9) & 182(60.1) & $505(59.3)$ \\
\hline Female & $225(41.1)$ & 121(39.9) & $346(40.7)$ \\
\hline Pregnant at randomization & $4(0.7)$ & & $4(0.5)$ \\
\hline \multicolumn{4}{|l|}{ Ethnicity } \\
\hline White & $94(17.2)$ & $44(14.5)$ & 138(16.2) \\
\hline Asian & $267(48.7)$ & $150(49.5)$ & $417(49.0)$ \\
\hline Hispanic or Latino & $21(3.8)$ & $11(3.6)$ & $32(3.8)$ \\
\hline Black & $29(5.3)$ & $8(2.6)$ & $37(4.3)$ \\
\hline Other & $34(6.2)$ & 28(9.2) & $62(7.3)$ \\
\hline Unknown & 103(18.8) & $62(20.5)$ & $165(19.4)$ \\
\hline \multicolumn{4}{|l|}{ ABO blood group } \\
\hline $\mathrm{O}$ & 236(43.1) & 111(36.6) & $347(40.8)$ \\
\hline$A$ & $206(37.6)$ & $117(38.6)$ & $323(38.0)$ \\
\hline$B$ & $78(14.2)$ & $53(17.5)$ & $131(15.4)$ \\
\hline$A B$ & $28(5.1)$ & $22(7.3)$ & $50(5.9)$ \\
\hline BMI - kg/m² & $30.1 \pm 7.6 ; 29(25,33)$ & $30.0 \pm 7.5 ; 29(25,33)$ & $\begin{array}{l}30.1 \pm 7.5 ; 29 \\
(25,33)\end{array}$ \\
\hline $\mathrm{BMI}<30$ & $220(40.1)$ & 121(39.9) & $341(40.1)$ \\
\hline $\mathrm{BMI} \geq 30$ & $177(32.3)$ & $100(33.0)$ & $277(32.5)$ \\
\hline Unknown & $151(27.6)$ & $82(27.1)$ & $233(27.4)$ \\
\hline \multicolumn{4}{|l|}{ Smoking status } \\
\hline Never Smoking & 291(53.1) & $157(51.8)$ & $448(52.6)$ \\
\hline Former Smoker & 165(30.1) & $103(34.0)$ & 268(31.5) \\
\hline Current Smoker & $16(2.9)$ & $6(2.0)$ & $22(2.6)$ \\
\hline
\end{tabular}




\begin{tabular}{|c|c|c|c|}
\hline Characteristic & $\begin{array}{l}\text { Convalescent Plasma } \\
\qquad n=548\end{array}$ & $\begin{array}{c}\text { Standard of Care } \\
n=303\end{array}$ & $\begin{array}{l}\text { Overall } \\
n=851\end{array}$ \\
\hline Unknown & $76(13.9)$ & $37(12.2)$ & $113(13.3)$ \\
\hline \multicolumn{4}{|l|}{ Smoking history } \\
\hline$<15$ years or non-smoker & $319(58.2)$ & $170(56.1)$ & $489(57.5)$ \\
\hline$\geq 15$ years & $73(13.3)$ & $52(17.2)$ & $125(14.7)$ \\
\hline Smokers with unknown history & $80(14.6)$ & $44(14.5)$ & $124(14.6)$ \\
\hline Unknown & $76(13.9)$ & $37(12.2)$ & $113(13.3)$ \\
\hline \multicolumn{4}{|l|}{ Presence of comorbidity } \\
\hline Diabetes & 184(33.6) & 104(34.3) & 288(33.8) \\
\hline Cardiac disease & $328(59.9)$ & 193(63.7) & $521(61.2)$ \\
\hline Baseline respiratory diseases & $130(23.7)$ & $79(26.1)$ & $209(24.6)$ \\
\hline $\begin{array}{l}\text { Abnormal CT chest or chest } \mathrm{X}- \\
\text { ray result before randomization }\end{array}$ & 494(90.1) & 258(85.1) & $752(88.4)$ \\
\hline \multicolumn{4}{|l|}{$\begin{array}{l}\text { Medication for other research } \\
\text { study at baseline }\end{array}$} \\
\hline No & $504(92.0)$ & 263(86.8) & $767(90.1)$ \\
\hline Yes & $44(8.0)$ & $40(13.2)$ & $84(9.9)$ \\
\hline \multicolumn{4}{|l|}{$\begin{array}{l}\text { Medication for COVID-19 at } \\
\text { baseline }\end{array}$} \\
\hline Azithromycin & $244(44.5)$ & $132(43.6)$ & $376(44.2)$ \\
\hline Other antibiotics & $353(64.4)$ & 181(59.7) & $534(62.7)$ \\
\hline Steroid/Immunomodulator & $434(79.2)$ & $240(79.2)$ & $674(79.2)$ \\
\hline Antiviral medications & $144(26.3)$ & $78(25.7)$ & $222(26.1)$ \\
\hline Anticoagulants & $304(55.5)$ & $172(56.8)$ & $476(55.9)$ \\
\hline Other COVID-19 Medications & $69(12.6)$ & $36(11.9)$ & $105(12.3)$ \\
\hline \multicolumn{4}{|l|}{$\begin{array}{l}\text { Medication not for COVID-19 at } \\
\text { baseline }\end{array}$} \\
\hline ACE inhibitor & $74(13.5)$ & $62(20.5)$ & $136(16.0)$ \\
\hline ACE receptor blocker(ARB) & $63(11.5)$ & $46(15.2)$ & 109(12.8) \\
\hline $\begin{array}{l}\text { Non-steroidal anti-inflammatory } \\
\text { drugs(NSAIDs) }\end{array}$ & $69(12.6)$ & $51(16.8)$ & $120(14.1)$ \\
\hline Colchicine & $5(0.9)$ & $2(0.7)$ & $7(0.8)$ \\
\hline Systemic corticosteroids & $54(9.9)$ & $35(11.6)$ & $89(10.5)$ \\
\hline Inhaled corticosteroids & $76(13.9)$ & $41(13.5)$ & $117(13.7)$ \\
\hline
\end{tabular}


medRxiv preprint doi: https://doi.org/10.1101/2021.06.29.21259427; this version posted July 3, 2021. The copyright holder for this preprint (which was not certified by peer review) is the author/funder, who has granted medRxiv a license to display the preprint in perpetuity.

It is made available under a CC-BY-NC-ND 4.0 International license .

\begin{tabular}{|l|c|c|c|}
\hline \multicolumn{1}{|c|}{ Characteristic } & $\begin{array}{c}\text { Convalescent Plasma } \\
\mathbf{n = 5 4 8}\end{array}$ & $\begin{array}{c}\text { Standard of Care } \\
\mathbf{n = 3 0 3}\end{array}$ & $\begin{array}{c}\text { Overall } \\
\mathbf{n = 8 5 1}\end{array}$ \\
\hline \multicolumn{1}{|c|}{ Immunomodulatory agents } & $21(3.8)$ & $17(5.6)$ & $38(4.5)$ \\
\multicolumn{1}{|c|}{ Anticoagulants } & $114(20.8)$ & $63(20.8)$ & $177(20.8)$ \\
Oxygen status at baseline (FiO $\mathbf{2})$ & $49.9 \pm 25.6 ; 40(30,70)$ & $\begin{array}{c}49.1 \pm 25.3 ; 40 \\
(30,60)\end{array}$ & $\begin{array}{c}49.6 \pm 25.5 ; 40 \\
(30,65)\end{array}$ \\
$\begin{array}{l}\text { Time from any symptom onset to } \\
\text { randomization (days) }\end{array}$ & $8.0 \pm 3.8 ; 8(5,10)$ & $7.8 \pm 3.4 ; 8(5,10)$ & $7.9 \pm 3.7 ; 8(5,10)$ \\
$\begin{array}{l}\text { Time from Covid-19 diagnosis } \\
\text { to randomization (days) }\end{array}$ & $5.0 \pm 3.6 ; 4(2,8)$ & $5.0 \pm 4.4 ; 4(2,7)$ & $5.0 \pm 3.9 ; 4(2,7)$ \\
\begin{tabular}{l} 
Enrolled in other clinical trials \\
\hline
\end{tabular} & $143(26.1)$ & $96(31.7)$ & $239(28.1)$ \\
\hline
\end{tabular}

aDay of positive Covid-19 test. 
eTable 4: Primary and secondary end points for the per protocol population.

\begin{tabular}{|c|c|c|c|c|}
\hline Per protocol analysis & $\begin{array}{l}\text { Populati } \\
\text { on }\end{array}$ & $\begin{array}{l}\text { CCP } \\
n=548\end{array}$ & $\begin{array}{l}\text { SOC } \\
n=303\end{array}$ & Treatment effect $^{\mathrm{a}}$ \\
\hline Intubation or death at day30 & $851^{b}$ & $\begin{array}{c}167(30 . \\
5)\end{array}$ & $85(28.1)$ & $\begin{array}{l}\mathrm{RR}=1.09(0.87,1.35) \\
p=0.4612\end{array}$ \\
\hline $\begin{array}{l}\text { Time to Intubation or in-hospital } \\
\text { death }\end{array}$ & 851 & & & $\begin{array}{l}H R=1.062(0.819,1.376), \\
p=0.6516\end{array}$ \\
\hline \multicolumn{5}{|l|}{ (days) by day30 } \\
\hline $\begin{array}{l}\text { Number of ventilation-free days } \\
\text { by day30 }\end{array}$ & 851 & $\begin{array}{c}23.9 \pm 10 \\
.2\end{array}$ & $\begin{array}{l}24.0 \pm 10 \\
5\end{array}$ & $\begin{array}{l}M D=-0.1(-1.5,1.3) \\
p=0.8520\end{array}$ \\
\hline Any death by day30 & 851 & $\begin{array}{l}114(20 . \\
8)\end{array}$ & $62(20.5)$ & $\begin{array}{l}R R=1.02(0.77,1.34) \\
p=0.9065\end{array}$ \\
\hline Length of stay in ICU by day 30 & 851 & $4.3 \pm 8.0$ & $3.7 \pm 7.1$ & $\begin{array}{l}\mathrm{MD}=0.6(-0.4,1.7) \\
\mathrm{p}=0.2485\end{array}$ \\
\hline $\begin{array}{l}\text { Need for Renal replacement } \\
\text { therapy by }\end{array}$ & 842 & $7(1.3)$ & $6(2.0)$ & $\begin{array}{l}R R=0.64(0.22,1.89) \\
p=0.4225\end{array}$ \\
\hline \multicolumn{5}{|l|}{ day30c } \\
\hline Serious Adverse event by day 30 & 851 & $\begin{array}{c}172(31 . \\
4)\end{array}$ & $80(26.4)$ & $\begin{array}{l}R R=1.19(0.95,1.49) \\
p=0.1321\end{array}$ \\
\hline Per protocol analysis & & $n=557$ & $n=309$ & Treatment effect \\
\hline In-hospital death by day 90 & $866^{d}$ & $\begin{array}{c}127(22 . \\
8)\end{array}$ & $68(22.0)$ & $\begin{array}{l}R R=1.04(0.80,1.34) \\
p=0.7890\end{array}$ \\
\hline $\begin{array}{l}\text { Time to in-hospital death by day } \\
90\end{array}$ & 866 & & & $\begin{array}{l}H R=0.946(0.704,1.270), \\
p=0.946\end{array}$ \\
\hline $\begin{array}{l}\text { Length of stay in hospital by day } \\
90\end{array}$ & 866 & & & $\begin{array}{l}H R=0.930(0.810,1.067), \\
p=0.2999\end{array}$ \\
\hline
\end{tabular}

\footnotetext{
${ }^{a}$ Relative Risk (RR, 95\% confidence interval), Hazard Ratio (HR, 95\% confidence interval) and Mean Difference (MD, with 95\% Cl based on robust bootstrap standard errors)

bee Figure 1 for exclusions to the per protocol population

${ }^{c}$ Excluding 9 patients on chronic kidney replacement therapy at baseline

dincluding 15 additional patients above the per-protocol, $\mathrm{n}=851$, who were lost to follow-up after discharge from hospital
} 
medRxiv preprint doi: https://doi.org/10.1101/2021.06.29.21259427; this version posted July 3, 2021. The copyright holder for this preprint (which was not certified by peer review) is the author/funder, who has granted medRxiv a license to display the preprint in perpetuity.

It is made available under a CC-BY-NC-ND 4.0 International license .

eTable 5: Antibody test results overall and by participating blood supplier.

\begin{tabular}{|c|c|c|}
\hline & $\begin{array}{l}\text { CCP units } \\
n=1192\end{array}$ & $\begin{array}{c}\text { Concentration } \\
\text { Median }(\mathrm{Q} 1, \mathrm{Q} 3)(\mathrm{min}, \max )\end{array}$ \\
\hline \multicolumn{3}{|l|}{$\mathrm{ADCC}_{\text {ratio }}{ }^{\mathrm{a}}$} \\
\hline All sites & $1186(99.5)$ & $1.359(0.603,3.051)(0.127,15.481)$ \\
\hline Supplier 1 & $553(99.1)$ & $2.284(0.788,4.375)(0.127,15.481)$ \\
\hline Supplier 2 & $454(100.0)$ & $1.122(0.571,2.437)(0.127,10.321)$ \\
\hline Supplier 3 & $174(100.0)$ & $0.583(0.351,1.091)(0.127,3.568)$ \\
\hline Supplier 4 & $5(83.3)$ & $0.844(0.599,1.506)(0.196,1.795)$ \\
\hline \multicolumn{3}{|l|}{ Anti-RBD ELISA ${ }^{b}$} \\
\hline All sites & $1186(99.5)$ & $1.410(0.959,1.836)(0.215,2.943)$ \\
\hline Supplier 1 & $553(99.1)$ & $1.638(1.342,2.029) \quad(0.215,2.829)$ \\
\hline Supplier 2 & $454(100.0)$ & $1.102(0.668,1.678) \quad(0.304,2.943)$ \\
\hline Supplier 3 & $174(100.0)$ & $1.131(0.810,1.580)(0.232,2.423)$ \\
\hline Supplier 4 & $5(83.3)$ & $1.321(1.171,1.718)(0.758,2.011)$ \\
\hline \multicolumn{3}{|l|}{ Anti-S IgGc } \\
\hline All sites & $1186(99.5)$ & $2853(1372,4967)(117,30402)$ \\
\hline Supplier 1 & $553(99.1)$ & $3530(2116,5547)(117,15506)$ \\
\hline Supplier 2 & $454(100.0)$ & $2308(1248,4967)(261,30402)$ \\
\hline Supplier 3 & $174(100.0)$ & $1333(578,2469)(193,9271)$ \\
\hline Supplier 4 & $5(83.3)$ & $2477(1974,2777)(700,10428)$ \\
\hline \multicolumn{3}{|l|}{ PRNT-50 ${ }^{\mathrm{d}, \mathrm{e}}$} \\
\hline All sites & 1191(99.9) & $160(80,320)(10,1280)$ \\
\hline Supplier 1 & $558(100.0)$ & $160(160,640)(40,1280)$ \\
\hline Supplier 2 & 454(100.0) & $80(20,160) \quad(10,640)$ \\
\hline Supplier 3 & 174(100.0) & $80(30,160)(10,640)$ \\
\hline Supplier 4 & $5(83.3)$ & $160(160,160)(80,160)$ \\
\hline
\end{tabular}

${ }^{a}$ Mean of $A D C C$ ratio (1-7 measures). ADCC \% with limit 11.3\% (equivalent to ratio 0.127); ADCC ratio=ADCC \%/(100 -ADCC\%)

${ }^{\mathrm{b}}$ Mean of anti-RBD ELISA conc. (1-8 measures)

'Mean of anti-S IgG conc. (1-7 measures)

${ }^{\mathrm{d}}$ Median of PRNT-50 (1-6 measures): PRNT-50 titer=1: $\mathrm{n}$ then PRNT=n, PRNT-50 titer $\geq 1: 1280$ then PRNT=1280, PRNT-50 titer $\geq 1: 640$ then PRNT=640, PRNT-50 titer=negative then PRNT=10

encludes interpolations (NYBC $n=6$ and CBS n=1) 
medRxiv preprint doi: https://doi.org/10.1101/2021.06.29.21259427; this version posted July 3, 2021. The copyright holder for this preprint (which was not certified by peer review) is the author/funder, who has granted medRxiv a license to display the preprint in perpetuity.

It is made available under a CC-BY-NC-ND 4.0 International license .

eTable 6: Adverse events at day 30 for the intention to treat population.

Categorical data presented as number (percentage) and continuous variables as mean \pm standard deviation and median (interquartile range).

\begin{tabular}{|c|c|c|c|}
\hline Intention to treat analysis & $\begin{array}{c}\text { Convalescent } \\
\text { Plasma } \\
n=614\end{array}$ & $\begin{array}{l}\text { Standard of Care } \\
n=307\end{array}$ & $\begin{array}{l}\text { Overall } \\
\mathrm{n}=921\end{array}$ \\
\hline \multicolumn{4}{|l|}{ Patients with adverse events } \\
\hline Grade $\geq 3$ (Severe) & $260(42.3)$ & 109(35.5) & $369(40.1)$ \\
\hline Grade $\geq 4$ (Life-Threatening) & 188(30.6) & $74(24.1)$ & $262(28.4)$ \\
\hline Grade 5 (Fatal) & $141(23.0)$ & $63(20.5)$ & $204(22.1)$ \\
\hline \multicolumn{4}{|l|}{ Number of adverse events per patient } \\
\hline Grade $\geq 3$ (Severe) & $0.9 \pm 1.7 ; 0(0,1)$ & $0.6 \pm 1.2 ; 0(0,1)$ & $0.8 \pm 1.5 ; 0(0,1)$ \\
\hline Grade $\geq 4$ (Life-Threatening) & $0.4 \pm 0.7 ; 0(0,1)$ & $0.3 \pm 0.7 ; 0(0,0)$ & $0.4 \pm 0.7 ; 0(0,1)$ \\
\hline Grade 5 (Fatal) & $0.2 \pm 0.4 ; 0(0,0)$ & $0.2 \pm 0.4 ; 0(0,0)$ & $0.2 \pm 0.4 ; 0(0,0)$ \\
\hline Serious adverse event (grade $\geq 3$ ) & $205(33.4)$ & $81(26.4)$ & $286(31.1)$ \\
\hline Number of SAEs per patient & $0.4 \pm 0.8 ; 0(0,1)$ & $0.3 \pm 0.7 ; 0(0,1)$ & $0.4 \pm 0.7 ; 0(0,1)$ \\
\hline \multicolumn{4}{|l|}{ Grade 3 non CCP related adverse event } \\
\hline Hypoxia & $23(3.7)$ & $7(2.3)$ & $30(3.3)$ \\
\hline Lymphocyte count decreased & $17(2.8)$ & $8(2.6)$ & $25(2.7)$ \\
\hline $\begin{array}{l}\text { Infections and infestations - Other, } \\
\text { specify }\end{array}$ & $15(2.4)$ & $8(2.6)$ & $23(2.5)$ \\
\hline Anemia & $15(2.4)$ & $3(1.0)$ & $18(2.0)$ \\
\hline Hyperglycemia & $13(2.1)$ & $5(1.6)$ & $18(2.0)$ \\
\hline Hypertension & $11(1.8)$ & $2(0.7)$ & $13(1.4)$ \\
\hline Pneumonitis & $10(1.6)$ & $1(0.3)$ & $11(1.2)$ \\
\hline Hypermagnesemia & $9(1.5)$ & $1(0.3)$ & $10(1.1)$ \\
\hline \multicolumn{4}{|c|}{ Grade 4 non CCP related adverse event } \\
\hline Hypoxia & $22(3.6)$ & $6(2.0)$ & $28(3.0)$ \\
\hline Acute kidney injury & $12(2.0)$ & $7(2.3)$ & $19(2.1)$ \\
\hline Sepsis & $8(1.3)$ & $4(1.3)$ & $12(1.3)$ \\
\hline \multicolumn{4}{|c|}{ Grade 5 non CCP related adverse event } \\
\hline Respiratory failure & $63(10.3)$ & $32(10.4)$ & $95(10.3)$ \\
\hline Hypoxia & $30(4.9)$ & $15(4.9)$ & $45(4.9)$ \\
\hline Death $^{a}$ & $14(2.3)$ & $4(1.3)$ & $18(2.0)$ \\
\hline
\end{tabular}


medRxiv preprint doi: https://doi.org/10.1101/2021.06.29.21259427; this version posted July 3, 2021. The copyright holder for this preprint (which was not certified by peer review) is the author/funder, who has granted medRxiv a license to display the preprint in perpetuity.

It is made available under a CC-BY-NC-ND 4.0 International license .

\begin{tabular}{|l|c|c|c|}
\hline Intention to treat analysis & $\begin{array}{c}\text { Convalescent } \\
\text { Plasma } \\
\mathrm{n}=614\end{array}$ & $\begin{array}{c}\text { Standard of Care } \\
\mathrm{n}=307\end{array}$ & $\begin{array}{c}\text { Overall } \\
\mathrm{n}=921\end{array}$ \\
\hline Grade $\geq 3$ non CCP related adverse event & $76(12.4)$ & $35(11.4)$ & $111(12.1)$ \\
Respiratory failure & $75(12.2)$ & $28(9.1)$ & $103(11.2)$ \\
Hypoxia & $17(2.8)$ & $8(2.6)$ & $25(2.7)$ \\
Lymphocyte count decreased & $16(2.6)$ & $8(2.6)$ & $24(2.6)$ \\
Infections and infestations - Other & $13(2.1)$ & $10(3.3)$ & $23(2.5)$ \\
Acute kidney injury & $14(2.3)$ & $7(2.3)$ & $21(2.3)$ \\
Sepsis & $16(2.6)$ & $3(1.0)$ & $19(2.1)$ \\
Anemia & $14(2.3)$ & $4(1.3)$ & $18(2.0)$ \\
Death & & $5(1.6)$ & $18(2.0)$ \\
Hyperglycemia & $13(2.1)$ & $3(1.0)$ & $13(1.4)$ \\
Adult respiratory distress syndrome & $10(1.6)$ & $4(1.3)$ & $13(1.4)$ \\
Dyspnea & $9(1.5)$ & $2(0.7)$ & $13(1.4)$ \\
Hypertension & $11(1.8)$ & $3(1.0)$ & $13(1.4)$ \\
Hypotension & $10(1.6)$ & $3(1.0)$ & $13(1.4)$ \\
Respiratory, thoracic, mediastinal & $10(1.6)$ & $4(1.3)$ & $13(1.4)$ \\
disorders & $9(1.5)$ & $5(1.6)$ & $12(1.3)$ \\
Lung infection & $7(1.1)$ & $1(0.3)$ & $11.2)$ \\
Thromboembolic event & $10(1.6)$ & & \\
Pneumonitis & $9(1.5)$ & & \\
Hypermagnesemia & & & \\
\hline
\end{tabular}

aAdverse event classified by the investigator as CTCAE term "death (not otherwise specified)". 
medRxiv preprint doi: https://doi.org/10.1101/2021.06.29.21259427; this version posted July 3, 2021. The copyright holder for this preprint (which was not certified by peer review) is the author/funder, who has granted medRxiv a license to display the preprint in perpetuity.

It is made available under a CC-BY-NC-ND 4.0 International license .

eTable 7: Adverse events at day 30 for the per protocol population.

Categorical data presented as number (percentage) and continuous variables as mean \pm standard deviation and median (interquartile range).

\begin{tabular}{|c|c|c|c|}
\hline Per protocol analysis & $\begin{array}{c}\text { Convalescent } \\
\text { Plasma } \\
n=548\end{array}$ & $\begin{array}{l}\text { Standard of Care } \\
\qquad n=303\end{array}$ & $\begin{array}{l}\text { Overall } \\
n=851\end{array}$ \\
\hline \multicolumn{4}{|l|}{ Patients with adverse events } \\
\hline Grade $\geq 3$ (Severe) & 218(39.8) & 108(35.6) & $326(38.3)$ \\
\hline Grade $\geq 4$ (Life-Threatening) & 156(28.5) & $73(24.1)$ & $229(26.9)$ \\
\hline Grade $\geq 5$ (Fatal) & $114(20.8)$ & $62(20.5)$ & $176(20.7)$ \\
\hline \multicolumn{4}{|l|}{ Number of adverse events per patient } \\
\hline Grade $\geq 3$ (Severe) & $0.8 \pm 1.7 ; 0(0,1)$ & $0.6 \pm 1.2 ; 0(0,1)$ & $0.7 \pm 1.5 ; 0(0,1)$ \\
\hline Grade $\geq 4$ (Life-Threatening) & $0.4 \pm 0.7 ; 0(0,1)$ & $0.3 \pm 0.7 ; 0(0,0)$ & $0.3 \pm 0.7 ; 0(0,1)$ \\
\hline Grade 5 (Fatal) & $0.2 \pm 0.4 ; 0(0,0)$ & $0.2 \pm 0.4 ; 0(0,0)$ & $\begin{array}{c}0.2 \pm 0.4 ; 0(0 \\
0)\end{array}$ \\
\hline Serious adverse event & $172(31.4)$ & $80(26.4)$ & $252(29.6)$ \\
\hline Number of SAEs per patient & $0.4 \pm 0.7 ; 0(0,1)$ & $0.3 \pm 0.7 ; 0(0,1)$ & $\begin{array}{l}0.4 \pm 0.7 ; 0(0 \\
1)\end{array}$ \\
\hline \multicolumn{4}{|l|}{ Grade 3 non CCP related adverse event } \\
\hline Hypoxia & $20(3.6)$ & $7(2.3)$ & $27(3.2)$ \\
\hline $\begin{array}{l}\text { Infections and infestations - Other, } \\
\text { specify }\end{array}$ & $14(2.6)$ & $8(2.6)$ & $22(2.6)$ \\
\hline Lymphocyte count decreased & $14(2.6)$ & $8(2.6)$ & $22(2.6)$ \\
\hline Anemia & $14(2.6)$ & $3(1.0)$ & $17(2.0)$ \\
\hline Hyperglycemia & $11(2.0)$ & $5(1.7)$ & $16(1.9)$ \\
\hline Hypertension & $10(1.8)$ & $2(0.7)$ & $12(1.4)$ \\
\hline Pneumonitis & $10(1.8)$ & $1(0.3)$ & $11(1.3)$ \\
\hline Hypermagnesemia & $8(1.5)$ & $1(0.3)$ & $9(1.1)$ \\
\hline Hypophosphatemia & $8(1.5)$ & $1(0.3)$ & $9(1.1)$ \\
\hline Urinary tract infection & $7(1.3)$ & $2(0.7)$ & $9(1.1)$ \\
\hline \multicolumn{4}{|l|}{ Grade 4 non CCP related adverse event } \\
\hline Hypoxia & $20(3.6)$ & $6(2.0)$ & $26(3.1)$ \\
\hline Acute kidney injury & $11(2.0)$ & $7(2.3)$ & $18(2.1)$ \\
\hline Sepsis & $8(1.5)$ & $4(1.3)$ & $12(1.4)$ \\
\hline
\end{tabular}




\begin{tabular}{|c|c|c|c|}
\hline Per protocol analysis & $\begin{array}{c}\text { Convalescent } \\
\text { Plasma } \\
n=548\end{array}$ & $\begin{array}{l}\text { Standard of Care } \\
n=303\end{array}$ & $\begin{array}{c}\text { Overall } \\
\mathrm{n}=851\end{array}$ \\
\hline \multicolumn{4}{|l|}{ Grade 5 non CCP related adverse event } \\
\hline Respiratory failure & $53(9.7)$ & $31(10.2)$ & $84(9.9)$ \\
\hline Hypoxia & $25(4.6)$ & $15(5.0)$ & $40(4.7)$ \\
\hline Death $^{a}$ & $11(2.0)$ & $4(1.3)$ & $15(1.8)$ \\
\hline \multicolumn{4}{|l|}{$\begin{array}{l}\text { Grade } 3 / 4 / 5 \text { non CCP related adverse } \\
\text { event }\end{array}$} \\
\hline Respiratory failure & $64(11.7)$ & $34(11.2)$ & $98(11.5)$ \\
\hline Hypoxia & $65(11.9)$ & $28(9.2)$ & $93(10.9)$ \\
\hline $\begin{array}{l}\text { Infections and infestations - Other, } \\
\text { specify }\end{array}$ & $14(2.6)$ & $8(2.6)$ & $22(2.6)$ \\
\hline Lymphocyte count decreased & $14(2.6)$ & $8(2.6)$ & $22(2.6)$ \\
\hline Acute kidney injury & $12(2.2)$ & $10(3.3)$ & $22(2.6)$ \\
\hline Sepsis & $13(2.4)$ & $7(2.3)$ & $20(2.4)$ \\
\hline Anemia & $15(2.7)$ & $3(1.0)$ & $18(2.1)$ \\
\hline Hyperglycemia & $11(2.0)$ & $5(1.7)$ & $16(1.9)$ \\
\hline Death $^{a}$ & $11(2.0)$ & $4(1.3)$ & $15(1.8)$ \\
\hline Dyspnea & $8(1.5)$ & $4(1.3)$ & $12(1.4)$ \\
\hline Hypertension & $10(1.8)$ & $2(0.7)$ & $12(1.4)$ \\
\hline $\begin{array}{l}\text { Respiratory, thoracic and mediastinal } \\
\text { disorders }\end{array}$ & $9(1.6)$ & $3(1.0)$ & $12(1.4)$ \\
\hline Lung infection & $8(1.5)$ & $4(1.3)$ & $12(1.4)$ \\
\hline Pneumonitis & $10(1.8)$ & $1(0.3)$ & $11(1.3)$ \\
\hline Thromboembolic event & $6(1.1)$ & $5(1.7)$ & $11(1.3)$ \\
\hline Adult respiratory distress syndrome & $7(1.3)$ & $3(1.0)$ & $10(1.2)$ \\
\hline Hypotension & $7(1.3)$ & $3(1.0)$ & $10(1.2)$ \\
\hline Hypermagnesemia & $8(1.5)$ & $1(0.3)$ & $9(1.1)$ \\
\hline Hypophosphatemia & $8(1.5)$ & $1(0.3)$ & $9(1.1)$ \\
\hline Urinary tract infection & $7(1.3)$ & $2(0.7)$ & $9(1.1)$ \\
\hline
\end{tabular}

aAdverse event classified by the investigator as CTCAE term "death (not otherwise specified)". 
medRxiv preprint doi: https://doi.org/10.1101/2021.06.29.21259427; this version posted July 3, 2021. The copyright holder for this preprint (which was not certified by peer review) is the author/funder, who has granted medRxiv a license to display the preprint in perpetuity.

It is made available under a CC-BY-NC-ND 4.0 International license .

eTable 8: Convalescent plasma adverse events at day 30 for the intention to treat population.

\begin{tabular}{|c|c|}
\hline Intention to treat analysis & $\begin{array}{c}\text { Convalescent } \\
\text { Plasma } \\
n=614\end{array}$ \\
\hline \multicolumn{2}{|l|}{ CCP related adverse event, $n$} \\
\hline CTCAE Grade 1 & $10(1.6)$ \\
\hline CTCAE Grade 2 & $10(1.6)$ \\
\hline CTCAE Grade 3 (Severe) & $8(1.3)$ \\
\hline $\begin{array}{l}\text { CTCAE Grade } 4 \text { (Life- } \\
\text { Threatening) }\end{array}$ & $4(0.7)$ \\
\hline \multicolumn{2}{|l|}{ CTCAE Grade 5 (Fatal) } \\
\hline $\begin{array}{l}\text { Number of CCP related AEs per } \\
\text { patient* }^{\star}\end{array}$ & $0.0 \pm 0.1 ; 0(0,0)$ \\
\hline CTCAE Grade 1 & $0.0 \pm 0.1 ; 0(0,0)$ \\
\hline CTCAE Grade 2 & $0.0 \pm 0.1 ; 0(0,0)$ \\
\hline CTCAE Grade 3 (Severe) & $0.0 \pm 0.1 ; 0(0,0)$ \\
\hline $\begin{array}{l}\text { CTCAE Grade } 4 \text { (Life- } \\
\text { Threatening) }\end{array}$ & $0.0 \pm 0.0 ; 0(0,0)$ \\
\hline \multicolumn{2}{|l|}{ CTCAE Grade 5 (Fatal) } \\
\hline \multicolumn{2}{|l|}{ CCP related adverse event, $\mathrm{n}$} \\
\hline ISBT Grade 1 & $18(2.9)$ \\
\hline ISBT Grade 2 & $10(1.6)$ \\
\hline ISBT Grade 3 & $4(0.7)$ \\
\hline \multicolumn{2}{|l|}{ ISBT Grade 4} \\
\hline \multicolumn{2}{|l|}{$\begin{array}{l}\text { Number of CCP related AEs per } \\
\text { patient }^{\mathrm{a}}\end{array}$} \\
\hline ISBT Grade 1 & $0.0 \pm 0.2 ; 0(0,0)$ \\
\hline ISBT Grade 2 & $0.0 \pm 0.1 ; 0(0,0)$ \\
\hline ISBT Grade 3 & $0.0 \pm 0.1 ; 0(0,0)$ \\
\hline ISBT Grade 4 & $0.0 \pm 0.0 ; 0(0,0)$ \\
\hline \multicolumn{2}{|l|}{ Event name, $\mathrm{n}$} \\
\hline TAD & $13(2.1)$ \\
\hline Minor Allergic Reaction & $9(1.5)$ \\
\hline TACO & $5(0.8)$ \\
\hline
\end{tabular}


medRxiv preprint doi: https://doi.org/10.1101/2021.06.29.21259427; this version posted July 3, 2021. The copyright holder for this preprint (which was not certified by peer review) is the author/funder, who has granted medRxiv a license to display the preprint in perpetuity. It is made available under a CC-BY-NC-ND 4.0 International license .

\begin{tabular}{|l|c|}
\hline Intention to treat analysis & $\begin{array}{c}\text { Convalescent } \\
\text { Plasma } \\
\mathrm{n}=614\end{array}$ \\
\hline Febrile Non-Hemolytic Reaction & $4(0.7)$ \\
Other (Hypertensive Reaction) & $2(0.3)$ \\
Hypotensive Reaction & $1(0.2)$ \\
Possible TRALI & $1(0.2)$ \\
\hline
\end{tabular}

${ }^{\mathrm{a} M e a n / s t a n d a r d ~ d e v i a t i o n) ; ~ m e d i a n ~(i n t e r q u a r t i l e ~ r a n g e) ~}$ 
medRxiv preprint doi: https://doi.org/10.1101/2021.06.29.21259427; this version posted July 3, 2021. The copyright holder for this preprint (which was not certified by peer review) is the author/funder, who has granted medRxiv a license to display the preprint in perpetuity.

It is made available under a CC-BY-NC-ND 4.0 International license .

eTable 9: Convalescent plasma adverse events at day 30 for the per protocol population.

\begin{tabular}{|c|c|}
\hline Per protocol analysis & $\begin{array}{c}\text { Convalescent } \\
\text { Plasma } \\
n=548\end{array}$ \\
\hline \multicolumn{2}{|l|}{ CCP related adverse event, $n$} \\
\hline CTCAE Grade 1 & $10(1.8)$ \\
\hline CTCAE Grade 2 & $10(1.8)$ \\
\hline CTCAE Grade 3 (Severe) & $4(0.7)$ \\
\hline $\begin{array}{l}\text { CTCAE Grade } 4 \text { (Life- } \\
\text { Threatening) }\end{array}$ & $4(0.7)$ \\
\hline \multicolumn{2}{|l|}{ CTCAE Grade 5 (Fatal) } \\
\hline $\begin{array}{l}\text { Number of CCP related AEs per } \\
\text { patient* }\end{array}$ & $0.0 \pm 0.2 ; 0(0,0)$ \\
\hline CTCAE Grade 1 & $0.0 \pm 0.2 ; 0(0,0)$ \\
\hline CTCAE Grade 2 & $0.0 \pm 0.1 ; 0(0,0)$ \\
\hline CTCAE Grade 3 (Severe) & $0.0 \pm 0.1 ; 0(0,0)$ \\
\hline $\begin{array}{l}\text { CTCAE Grade } 4 \text { (Life- } \\
\text { Threatening) }\end{array}$ & $0.0 \pm 0.0 ; 0(0,0)$ \\
\hline \multicolumn{2}{|l|}{ CTCAE Grade 5 (Fatal) } \\
\hline CCP related adverse event, $\mathrm{n}$ & $17(3.1)$ \\
\hline ISBT Grade 1 & $7(1.3)$ \\
\hline ISBT Grade 2 & $4(0.7)$ \\
\hline \multicolumn{2}{|l|}{ ISBT Grade 3} \\
\hline \multicolumn{2}{|l|}{ ISBT Grade 4} \\
\hline $\begin{array}{l}\text { Number of CCP related AEs per } \\
\text { patient }^{\mathrm{a}}\end{array}$ & $0.0 \pm 0.2 ; 0(0,0)$ \\
\hline ISBT Grade 1 & $0.0 \pm 0.1 ; 0(0,0)$ \\
\hline ISBT Grade 2 & $0.0 \pm 0.1 ; 0(0,0)$ \\
\hline ISBT Grade 3 & $0.0 \pm 0.0 ; 0(0,0)$ \\
\hline ISBT Grade 4 & $0.0 \pm 0.2 ; 0(0,0)$ \\
\hline \multicolumn{2}{|l|}{ Event name, $\mathrm{n}$} \\
\hline TAD & $10(1.8)$ \\
\hline Minor Allergic Reaction & $9(1.6)$ \\
\hline TACO & $5(0.9)$ \\
\hline
\end{tabular}


medRxiv preprint doi: https://doi.org/10.1101/2021.06.29.21259427; this version posted July 3, 2021. The copyright holder for this preprint (which was not certified by peer review) is the author/funder, who has granted medRxiv a license to display the preprint in perpetuity. It is made available under a CC-BY-NC-ND 4.0 International license .

\begin{tabular}{|l|c|}
\hline Per protocol analysis & $\begin{array}{c}\text { Convalescent } \\
\text { Plasma } \\
\mathrm{n}=548\end{array}$ \\
\hline Febrile Non-Hemolytic Reaction & $4(0.7)$ \\
Hypotensive Reaction & $1(0.2)$ \\
Other & $1(0.2)$ \\
Possible TRALI & $1(0.2)$ \\
\hline
\end{tabular}

${ }^{\mathrm{a} M e a n / s t a n d a r d ~ d e v i a t i o n) ; ~ m e d i a n ~(i n t e r q u a r t i l e ~ r a n g e) ~}$ 
medRxiv preprint doi: https://doi.org/10.1101/2021.06.29.21259427; this version posted July 3, 2021. The copyright holder for this preprint (which was not certified by peer review) is the author/funder, who has granted medRxiv a license to display the preprint in perpetuity.

It is made available under a CC-BY-NC-ND 4.0 International license .

\section{eTable 10: Summary of logistic regression models with standardized continuous log marker dose.}

The odds ratio reported in the third column reflects the effect modification corresponding to a 1 standard deviation unit increase in the log transformed and entered marker; in multivariate results markers other than the one labeled in the left column are set to mean log marker dose so the other covariates are zero. The convalescent plasma units transfused in the trial came from 530 distinct plasma donations. Five were missing all serologic marker values except for the original qualifying test and were excluded from analyses. Seven were missing only the neutralization titer value, which was interpolated from the other serologic markers, as described in the statistical analysis plan.

\begin{tabular}{|c|c|c|}
\hline $\begin{array}{l}\text { Intention to treat } \\
\text { analysis }\end{array}$ & $\begin{array}{c}\text { Treatment effect at mean } \\
\text { level of antibody, CCP vs. } \\
\text { SOC } \\
\text { OR }(95 \% \mathrm{Cl}), \mathrm{p} \text {-value }\end{array}$ & $\begin{array}{l}\text { OR for effect modification } \\
(95 \% \mathrm{Cl}), \mathrm{p} \text {-value }\end{array}$ \\
\hline \multicolumn{3}{|l|}{ Univariate analysis } \\
\hline ADCC assay & $\begin{array}{c}1.158(0.853,1.572) \\
p=0.3454\end{array}$ & $\begin{array}{c}0.757(0.620,0.924) \\
p=0.0062\end{array}$ \\
\hline Anti-RBD ELISA & $\begin{array}{c}1.167(0.860,1.584) \\
p=0.3205\end{array}$ & $\begin{array}{c}0.843(0.686,1.035) \\
p=0.1026\end{array}$ \\
\hline Anti-S IgG & $\begin{array}{c}1.164(0.859,1.579) \\
p=0.3275\end{array}$ & $\begin{array}{c}1.005(0.821,1.231) \\
p=0.9586\end{array}$ \\
\hline Neutralization & $\begin{array}{c}1.182(0.871,1.604) \\
p=0.2818\end{array}$ & $\begin{array}{c}0.768(0.629,0.937) \\
p=0.0095\end{array}$ \\
\hline \multicolumn{3}{|l|}{ Multivariate analysis } \\
\hline & $\begin{array}{c}1.143(0.840,1.555) \\
p=0.3940\end{array}$ & \\
\hline ADCC assay & & $\begin{array}{c}0.656(0.494,0.871) \\
p=0.0035\end{array}$ \\
\hline Anti-RBD ELISA & & $\begin{array}{c}1.018(0.753,1.376) \\
p=0.9076\end{array}$ \\
\hline Anti-S IgG & & $\begin{array}{c}1.528(1.140,2 \cdot 049) \\
\mathrm{p}=0.0046\end{array}$ \\
\hline Neutralization & & $\begin{array}{c}0.735(0.567,0.953) \\
p=0.0200\end{array}$ \\
\hline
\end{tabular}


medRxiv preprint doi: https://doi.org/10.1101/2021.06.29.21259427; this version posted July 3, 2021. The copyright holder for this preprint (which was not certified by peer review) is the author/funder, who has granted medRxiv a license to display the preprint in perpetuity. It is made available under a CC-BY-NC-ND 4.0 International license.

\section{Supplementary Figures}

\section{eFigure 1: Subgroup analysis for the per-protocol population.}

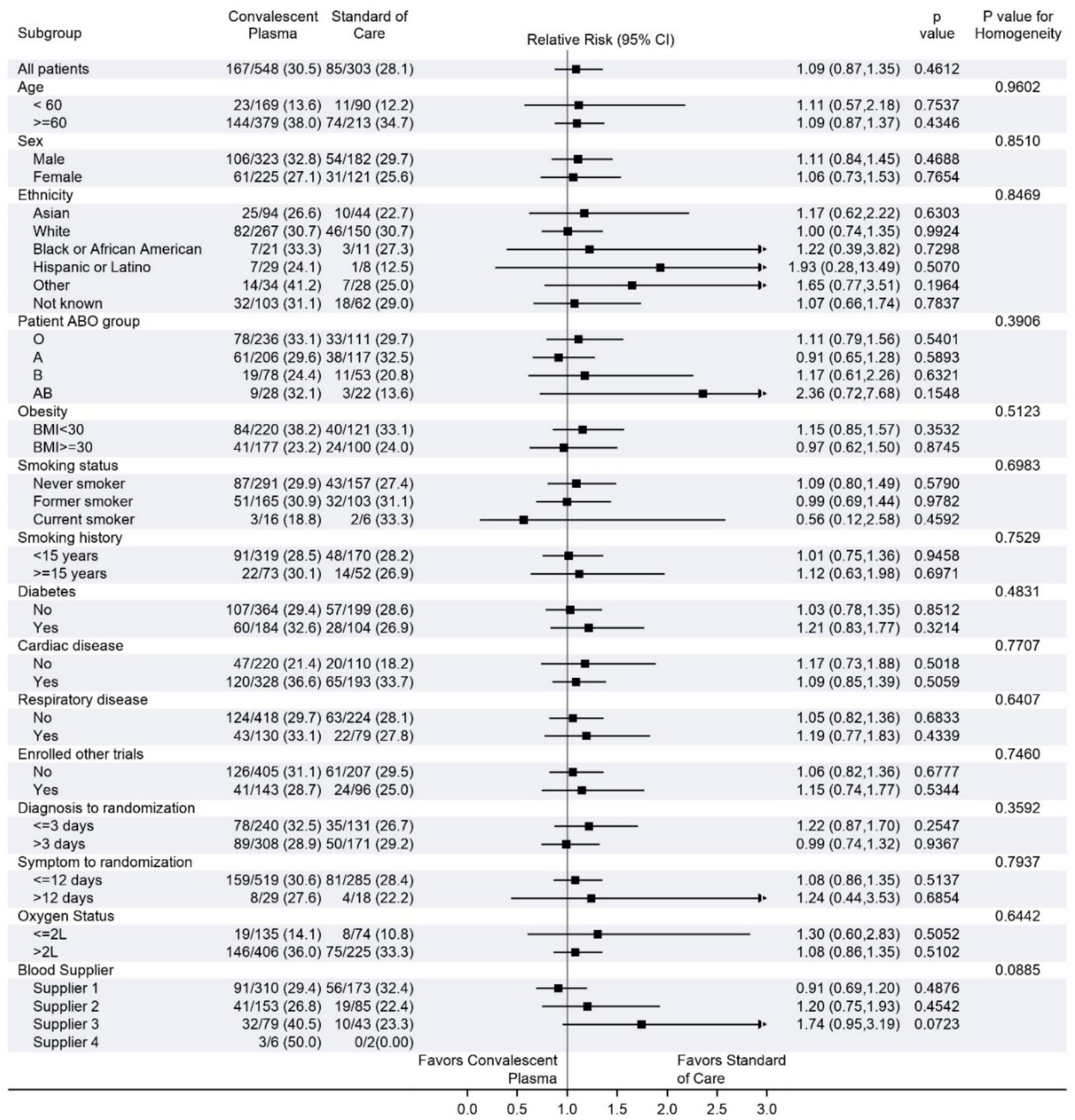

BMI: Body mass index 
medRxiv preprint doi: https://doi.org/10.1101/2021.06.29.21259427; this version posted July 3, 2021. The copyright holder for this preprint (which was not certified by peer review) is the author/funder, who has granted medRxiv a license to display the preprint in perpetuity.

eFigure 2: Cumulative incidence functions of intubation or in-hospital death by day 30 and in-hospital death by day 90, and Kaplan-Meier estimate of distribution of length of stay in hospital by day 90.

Figure S2a: Cumulative incidence function for intubation or in-hospital death by day 30 .
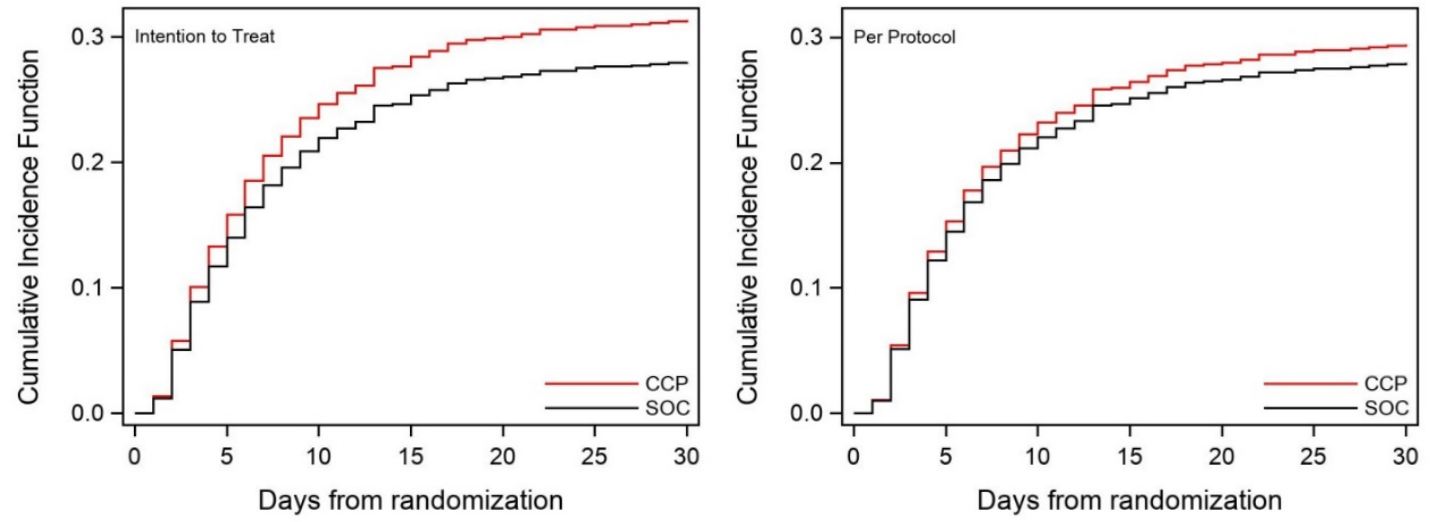

Figure S2b: Cumulative incidence function for in-hospital death or discharge from hospital by day 90 .
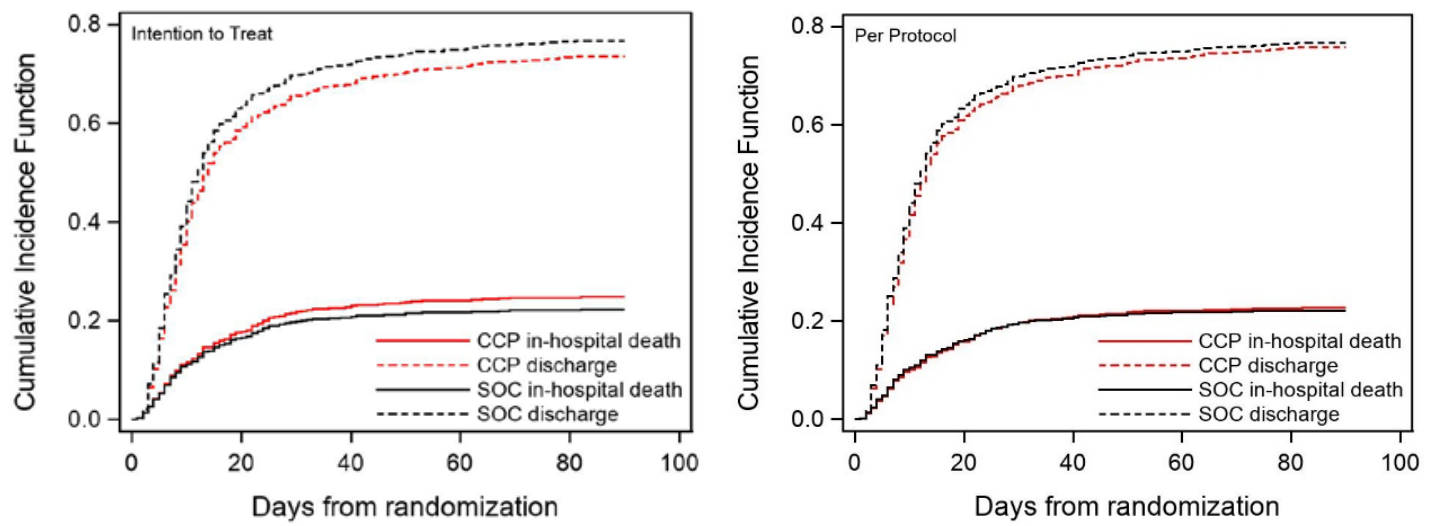

Figure S2c: Kaplan-Meier estimate of the cumulative distribution of length of stay in hospital ending with death or discharge by day 90 .
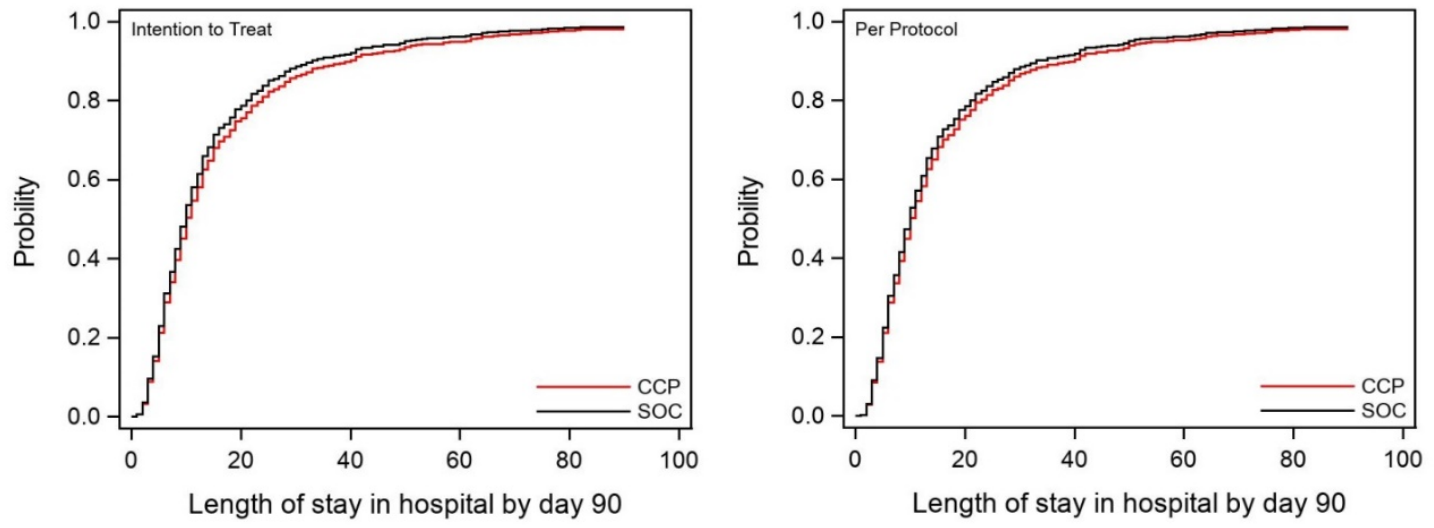
medRxiv preprint doi: https://doi.org/10.1101/2021.06.29.21259427; this version posted July 3, 2021. The copyright holder for this preprint (which was not certified by peer review) is the author/funder, who has granted medRxiv a license to display the preprint in perpetuity.

eFigure 3: Pairwise scatter plots of plasma antibody markers and empirical distribution functions.

Markers (log transformed and standardized) include Anti-RBD ELISA, plaque reduction neutralization test, Anti-S IgG and ADCC assay. ( $\rho$ : Pearson correlation coefficients of pair of antibody markers).
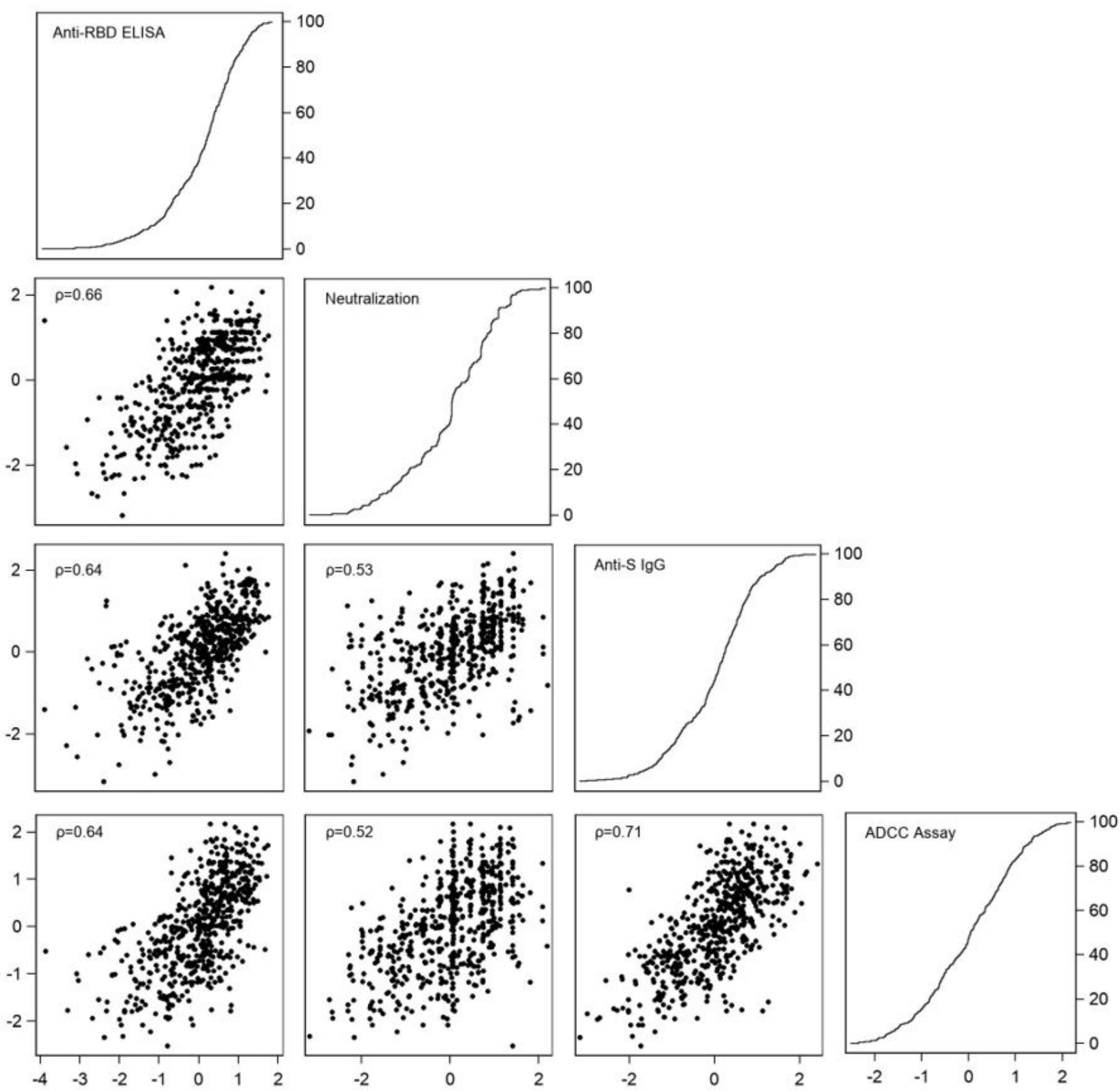
medRxiv preprint doi: https://doi.org/10.1101/2021.06.29.21259427; this version posted July 3, 2021. The copyright holder for this preprint (which was not certified by peer review) is the author/funder, who has granted medRxiv a license to display the preprint in perpetuity. It is made available under a CC-BY-NC-ND 4.0 International license .

eFigure 4: Exploration of the joint effect of antibody markers in convalescent plasma on the primary outcome. Contour plots of the odds ratio for the odds ratio for the composite event of intubation or death for individuals receiving blood as a function of the product of each possible pair of antibody markers. Over-layed data points indicate the value of the two antibody markers for each convalescent plasma transfusion in the study. The contours are obtained from a generalized additive logistic model for the primary outcome including blood supply center, treatment and the log transformed and standardized biomarkers using smoothing splines.

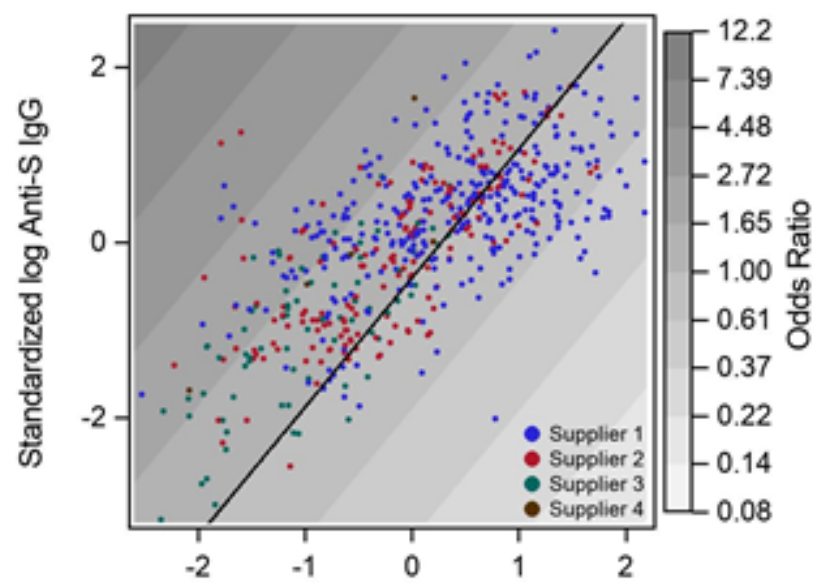

Standardized log ADCC Assay

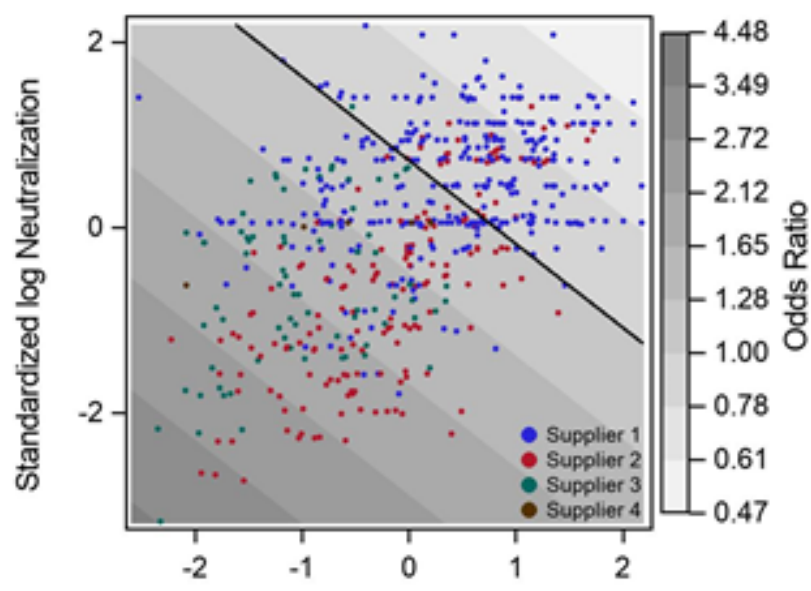

Standardized log ADCC Assay

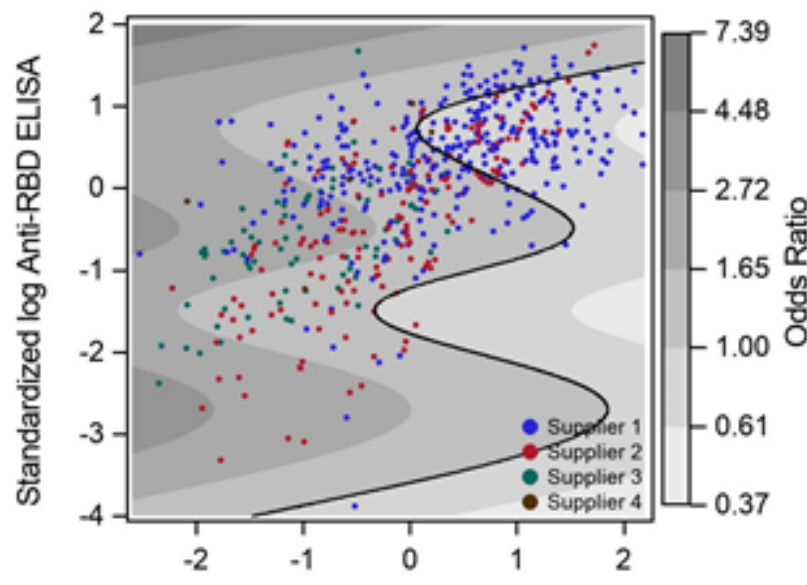

Standardized log ADCC Assay

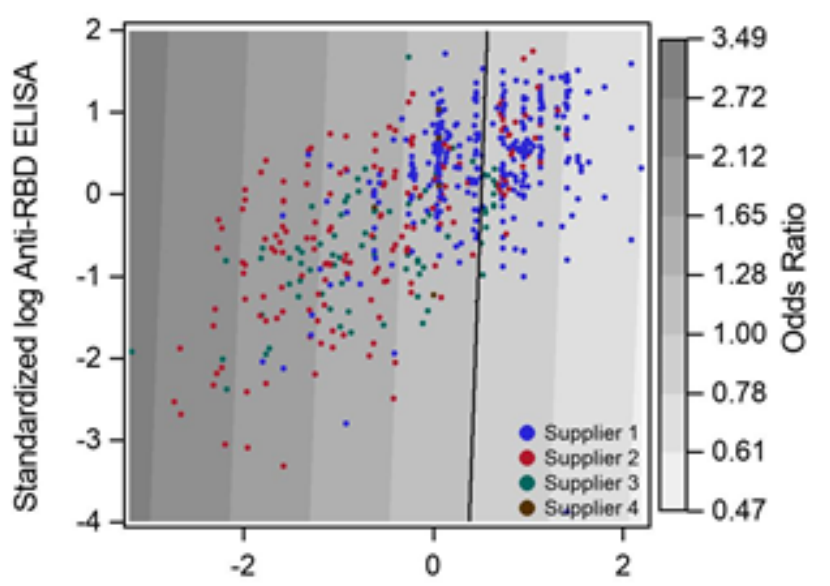

Standardized log Neutralization

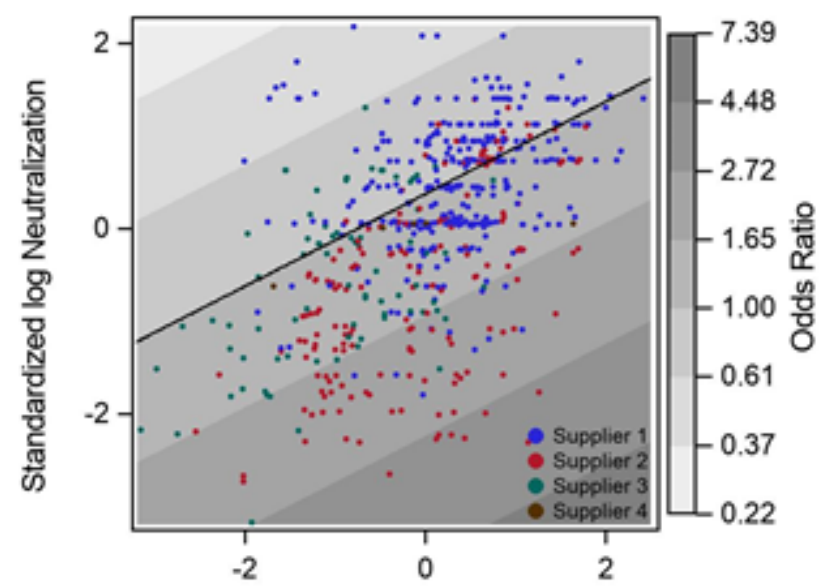

Standardized log Anti-S IgG

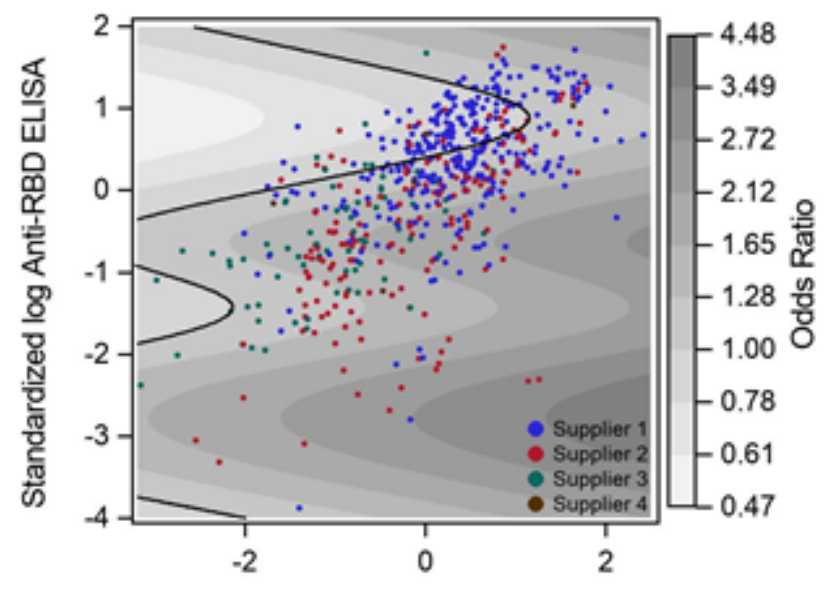

Standardized $\log$ Anti-S IgG 
medRxiv preprint doi: https://doi.org/10.1101/2021.06.29.21259427; this version posted July 3, 2021. The copyright holder for this preprint (which was not certified by peer review) is the author/funder, who has granted medRxiv a license to display the preprint in perpetuity.

It is made available under a CC-BY-NC-ND 4.0 International license .

\section{eFigure 5: Comparison of in-house ELISA to commercial assays.}

Values from the Héma-Québec in-house ELISA measuring antibody (IgM, IgA, IgG) binding the receptor binding domain of SARS-CoV-2 Spike protein (used in the current study) are compared to results from A) Euroimmun and B) Ortho Vitros commercial assays measuring IgG binding to subunit 1 of the SARS-CoV-2 Spike protein, which contains the receptor binding domain and which were used to qualify convalescent plasma in previous clinical trials. Each sample was tested with the commercial assays twice.

A

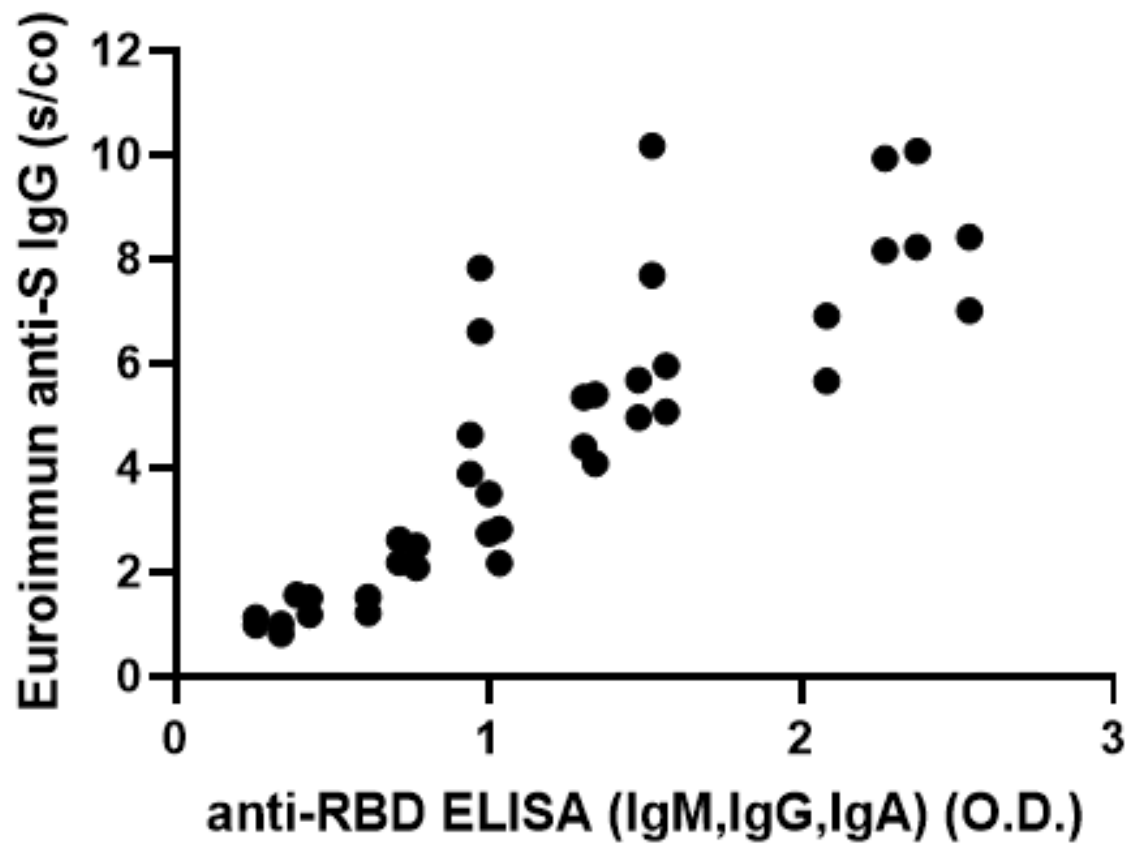

B

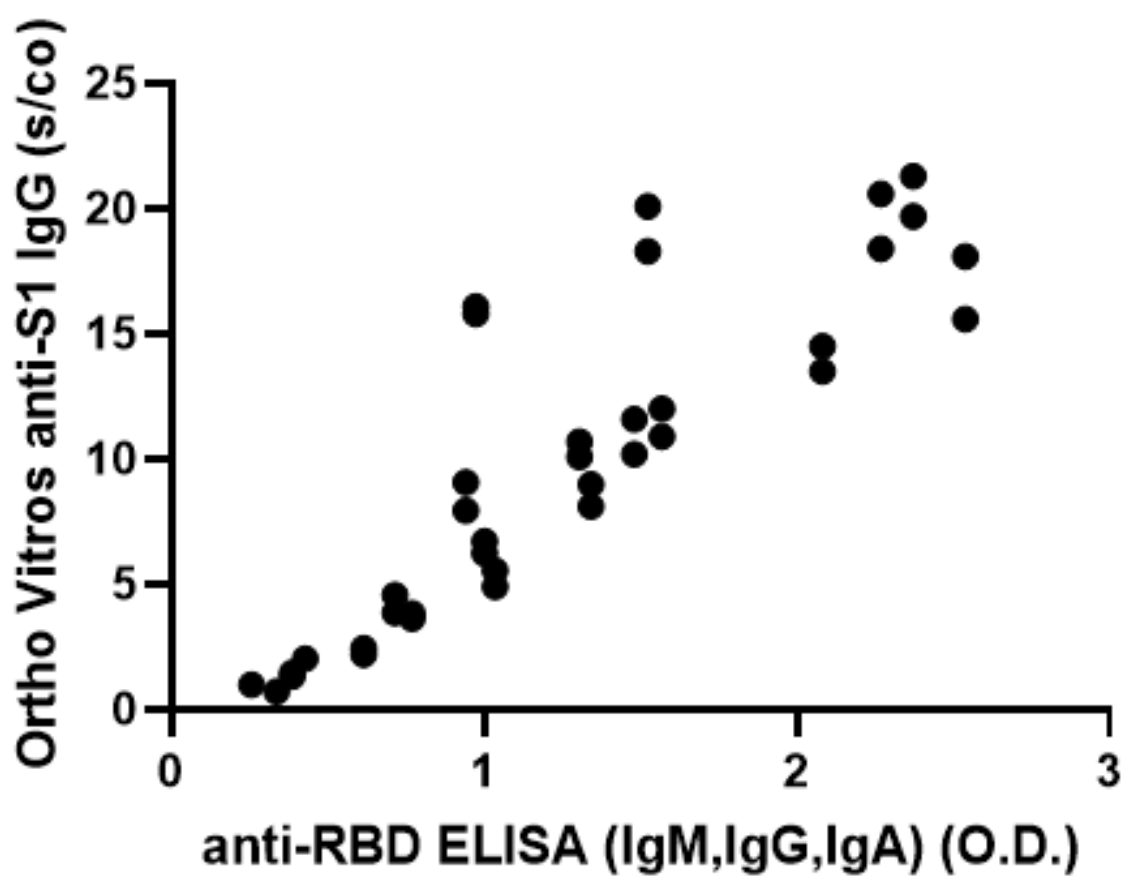


medRxiv preprint doi: https://doi.org/10.1101/2021.06.29.21259427; this version posted July 3, 2021. The copyright holder for this preprint (which was not certified by peer review) is the author/funder, who has granted medRxiv a license to display the preprint in perpetuity.

It is made available under a CC-BY-NC-ND 4.0 International license.

\section{References}

1. Harris PA, Taylor R, Thielke R, Payne J, Gonzalez N, Conde JG. Research electronic data capture (REDCap)--a metadata-driven methodology and workflow process for providing translational research informatics support. J Biomed Inform 2009;42(2):377-81. DOI: 10.1016/j.jbi.2008.08.010.

2. $\quad$ Anand SP, Prevost J, Richard J, et al. High-throughput detection of antibodies targeting the SARSCoV-2 Spike in longitudinal convalescent plasma samples. Transfusion 2021. DOI: 10.1111/trf.16318.

3. Anand SP, Prevost J, Nayrac M, et al. Longitudinal analysis of humoral immunity against SARS-CoV2 Spike in convalescent individuals up to eight months post-symptom onset. Cell Rep Med 2021:100290. DOI: 10.1016/j.xcrm.2021.100290.

4. Jennewein MF, MacCamy AJ, Akins NR, et al. Isolation and Characterization of Cross-Neutralizing Coronavirus Antibodies from COVID-19+ Subjects. bioRxiv 2021. DOI: 10.1101/2021.03.23.436684.

5. Abe KT, Li Z, Samson R, et al. A simple protein-based surrogate neutralization assay for SARS-CoV2. JCI Insight 2020;5(19). DOI: 10.1172/jci.insight.142362. 